\title{
ESTIMATION OF FLOOD VOLUMES AND SIMULATION \\ OF FLOOD HYDROGRAPHS FOR UNGAGED SMALL \\ RURAL STREAMS IN OHIO
}

By James M. Sherwood

\section{U.S. GEOLOGICAL SURVEY}

Water-Resources Investigations Report 93-4080

Final report on a study of

FLOOD VOLUME FREQUENCY FROM

SMALL DRAINAGE BASINS IN OHIO

Prepared in cooperation with the

OHIO DEPARTMENT OF TRANSPORTATION

and the

U.S. DEPARTMENT OF TRANSPORTATION, FEDERAL HIGHWAY ADMINISTRATION

The contents of this report reflect the views of the authors, who are responsible for the facts and the accuracy of the data presented herein. The contents do not necessarily reflect the official views or policies of the Ohio Department of Transportation or the Federal Highway Administration. This report does not constitute a standard, specification, or regulation.

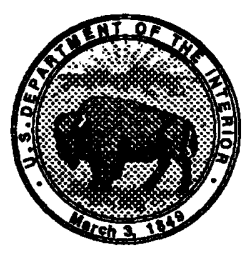

Columbus, Ohio 1993 


\section{U.S. DEPARTMENT OF THE INTERIOR BRUCE BABBITT, Secretary}

U.S. GEOLOGICAL SURVEY

ROBERT M. HIRSCH, Acting Director

Any use of trade names in this publication is for descriptive purposes only and does not imply endorsement by the U.S. Government.

For additional information

write to:

District Chief

Water Resources Division

U.S. Geological Surey

975 West Third Avenue

Columbus, $\mathrm{OH} 43212-3192$
Copies of this report may

be purchased from:

U.S. Geological Survey

Earth Science Information Center

Open-File Reports Section

Box 25286 MS 517

Denver Federal Center

Denver, CO 80225 


\section{CONTENTS}

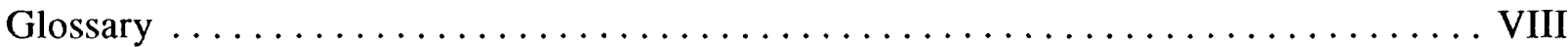

Abstract. ..................................... 1

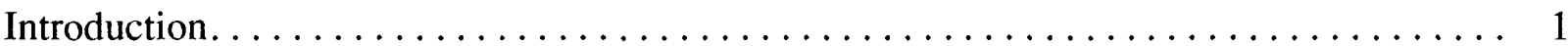

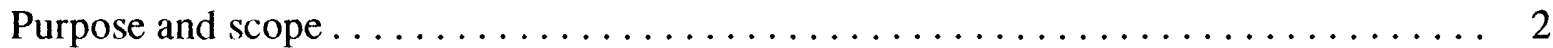

Previous work and approach to this study $\ldots \ldots \ldots \ldots \ldots \ldots \ldots \ldots \ldots \ldots \ldots$

Acknowledgements . . . . . . . . . . . . . . . . . . . . . . . . 4

Data collection ..................................... 4

Site reconnaissance and selection $\ldots \ldots \ldots \ldots \ldots \ldots \ldots \ldots \ldots \ldots \ldots \ldots$

Instrumentation of rainfall-runoff gaging stations $\ldots \ldots \ldots \ldots \ldots \ldots \ldots \ldots$

Collection and storage of data $\ldots \ldots \ldots \ldots \ldots \ldots \ldots \ldots \ldots \ldots \ldots \ldots \ldots \ldots \ldots$

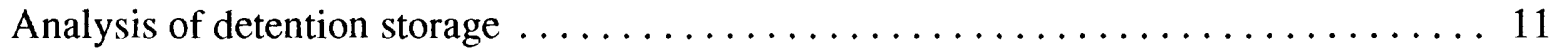

Analysis of flood volumes at streamflow-gaging stations $\ldots \ldots \ldots \ldots \ldots \ldots \ldots \ldots \ldots$

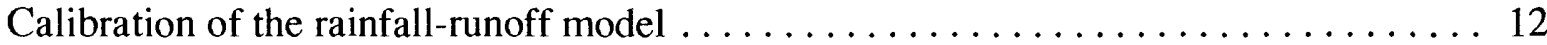

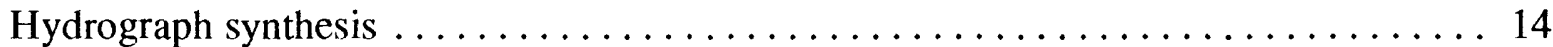

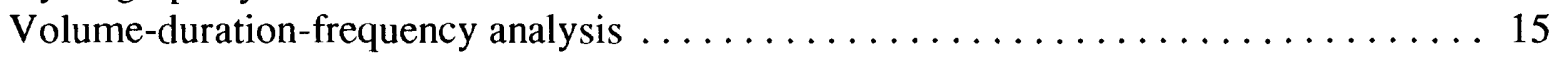

Estimation of flood volumes at ungaged rural sites $\ldots \ldots \ldots \ldots \ldots \ldots \ldots \ldots \ldots$

Development of equations for estimating flood volumes in Ohio $\ldots \ldots \ldots \ldots \ldots \ldots$

Flood volumes as a function of basin characteristics . . . . . . . . . . . . . . . 19

Tests for intercorrelation and bias. . . . . . . . . . . . . . . . . 23

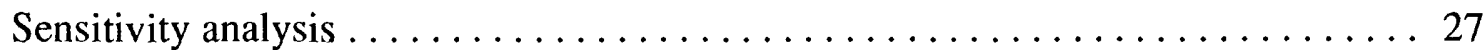

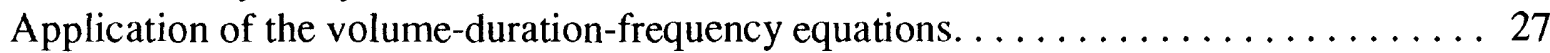

Limitations of the method . . . . . . . . . . . . . . . . . . . . 29

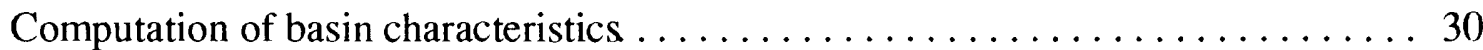

Computation of flood volumes as a function of duration . . . . . . . . . . . 30

Example of computation of flood volume. . . . . . . . . . . . . . 30

Computation of flood volumes as a function of time $\ldots \ldots \ldots \ldots \ldots \ldots \ldots \ldots$

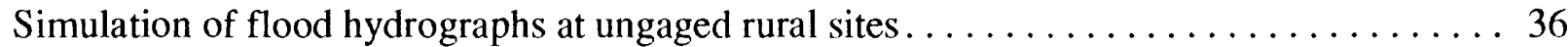

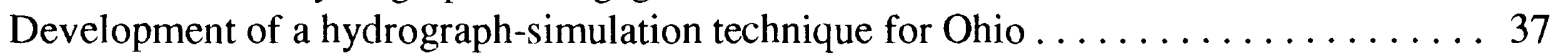

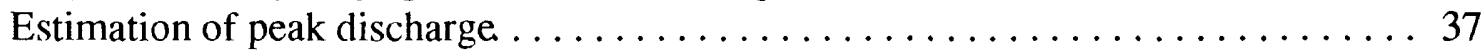

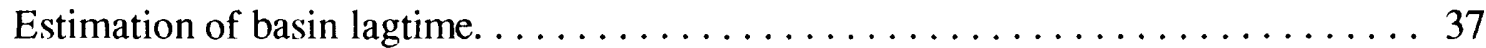

Selection and verification of dimensionless hydrograph $\ldots \ldots \ldots \ldots \ldots \ldots \ldots \ldots 40$

Application of the hydrograph-simulation technique $\ldots \ldots \ldots \ldots \ldots \ldots \ldots \ldots$

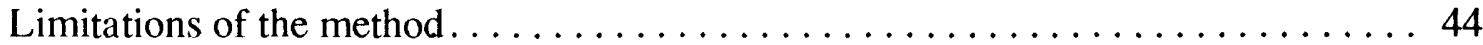

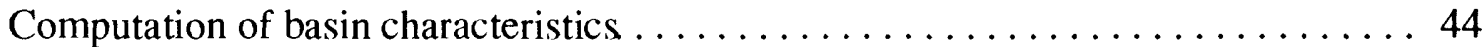

Computation of peak discharge. . . . . . . . . . . . . . . . . . 45

Computation of basin lagtime. . . . . . . . . . . . . . . . . . 45

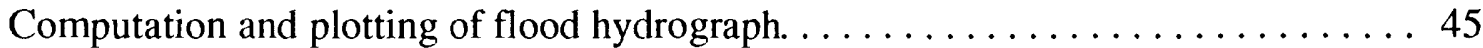

Example of computation of flood hydrograph $\ldots \ldots \ldots \ldots \ldots \ldots \ldots \ldots \ldots$

Computation of hydrograph volume. . . . . . . . . . . . . . . 46

Effects of storage area on hydrograph simulation. . . . . . . . . . . . . 48

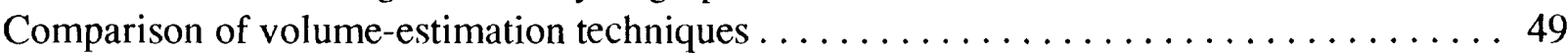

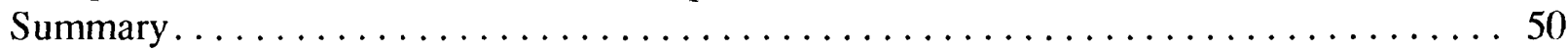

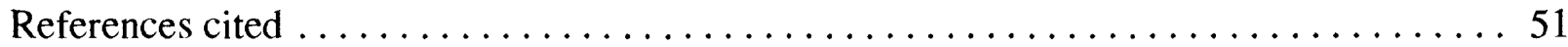


1. Map showing approximate locations of rural rainfall-runoff stations, long-term rainfall stations, and evaporation stations $\ldots \ldots \ldots \ldots \ldots \ldots$

2. Map showing approximate locations of urban rainfall-runoff stations $\ldots \ldots \ldots \ldots 7$

3. Photograph showing a typical rainfall-runoff data-collection station located on Elk Fork near Winchester, Ohio . . . . . . . . . . . . . . . . . . . . . 9

4. Graph showing simulated inflow hydrograph and observed outflow hydrograph for flood event of April 30, 1983, for Trippetts Branch at Camden, Ohio . . . . . . . . 12

5. Hydrograph showing selection of runoff data for computation of volume for each of six durations $(1,2,4,8,16$, and 32 hours $) \ldots \ldots \ldots \ldots \ldots \ldots \ldots \ldots \ldots \ldots \ldots \ldots \ldots \ldots \ldots$

6. Graphs showing 100-year flood volumes as a function of duration for six study sites in Ohio . . . . . . . . . . . . . . . . . . . . . . 18

7. Box plots showing the ranges, 25 th and 75 th percentiles, and median values of the four explanatory variables from 62 study sites in Ohio . . . . . . . . . . 21

8. Graph showing sensitivity of computed flood volume to changes from the means of the explanatory variables in the volume-duration-frequency $\left(\mathrm{dV}_{\mathrm{T}}\right)$ equations for selected durations and recurrence intervals. . . . . . . . . . . 28

9. Map showing average annual precipitation for Ohio for $1931-1980 \ldots \ldots \ldots \ldots 32$

10. Graph showing estimated 100 -year volume as a function of duration for an ungaged rural stream in eastern Adams County, Ohio . . . . . . . . . . . 31

11. Graphs showing illustration of a method to compute cumulative volume as a function of time $\left(\mathrm{VQ}_{\mathrm{T}}(\mathrm{t})\right)$ from volume as a function of duration $\left(\mathrm{dV}_{\mathrm{T}}\right) \ldots \ldots 34$

12. Graph showing estimated 100 -year volume as a function of time for an ungaged

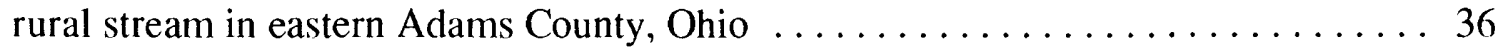

13. Map showing region boundaries for peak-discharge equations . . . . . . . . . 39

14. Graph showing sensitivity of basin lagtime (LT) to changes from the means of the explanatory variables in the basin lagtime equation $\ldots \ldots \ldots \ldots \ldots \ldots \ldots$

15. Graph showing dimensionless hydrograph $\ldots \ldots \ldots \ldots \ldots \ldots \ldots \ldots \ldots \ldots \ldots \ldots$

16. Graph showing observed and simulated hydrographs and respective differences in hydrograph widths $(\Delta \mathrm{W})$ at 75 and 50 percent of peak discharge for flood event of May 30, 1982 on Elk Fork at Winchester, Ohio . . . . . . . . . . . . . . . 43

17. Graph showing simulated flood hydrograph of estimated 100 -year peak discharge for an ungaged rural stream in eastern Adams County, Ohio . . . . . . . 46

18. Graph showing sensitivities of peak discharge $\left(\mathrm{Q}_{100}\right)$, basin lagtime $(\mathrm{LT})$, and flood volume $\left(\mathrm{VQ}_{100}\right)$ to changes in storage area $(\mathrm{ST})$ when simulating 100 -year flood hydrographs $\ldots \ldots \ldots \ldots \ldots \ldots \ldots \ldots \ldots \ldots \ldots \ldots \ldots \ldots$

19. Graph showing simulated flood hydrographs of estimated 100 -year peak discharge illustrating the effects of storage area (ST) on hydrograph shape . . . . . . . . . .

20. Graph showing volume estimated from 100-year volume-duration-frequency equations and volume integrated under 100-year estimated peak-discharge hydrograph for an ungaged rural stream in eastern Adams County, Ohio . . . . . . . . 


\section{TABLES}

1. Station numbers, station names, latitudes, and longitudes of 32 rural study sites in Ohio . . . . . . ............................. 6

2. Station numbers, station names, latitudes, and longitudes of 30 urban study sites in Ohio . . ................................. 6

3. Physical characteristics of the culverts at 32 rural study sites in Ohio . . . . . . 10

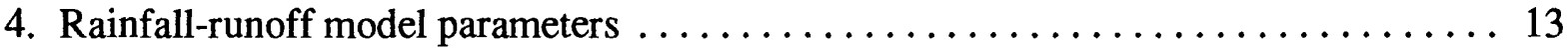

5. National Weather Service rainfall stations used in synthesis of hydrograph data . . . . 14

6. National Weather Service evaporation stations used in calibration of the rainfall-runoff models and in synthesis of hydrograph data $\ldots \ldots \ldots \ldots \ldots \ldots 14$

7. One-hundred-year volumes $\left(\mathrm{dV}_{100}\right)$ for 62 study sites in Ohio $\ldots \ldots \ldots \ldots \ldots 18$

8. Values of the significant explanatory variables in the volume-duration-frequency

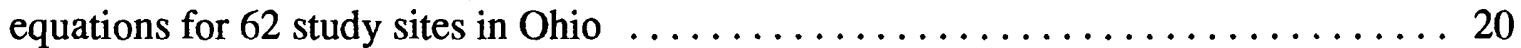

9. Equations for estimating volume-duration-frequency $\left(\mathrm{dV}_{\mathrm{T}}\right)$ relations of small

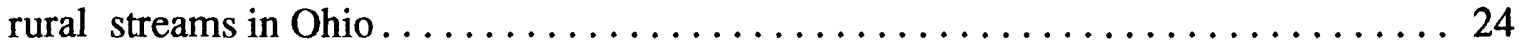

10. Alternate equations for estimating flood volumes of 1- and 2-hour durations and 25-, 50-, and 100-year recurrence intervals for small rural streams in Ohio. . . . 26

11. Computations of cumulative volume as a function of time $\left(\mathrm{VQ}_{\mathrm{T}}(\mathrm{t})\right)$ from volume as a function of duration $\left(\mathrm{dV}_{\mathrm{T}}\right)$ for an ungaged rural stream in eastern Adams

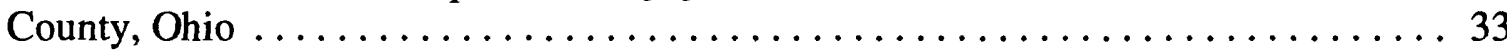

12. Equations for estimating peak discharges $\left(\mathrm{Q}_{\mathrm{T}}\right)$ of unregulated rural streams in Ohio.. 38

13. Values of basin lagtime, main-channel slope, forested area, and storage area for 32 rural study sites in Ohio used in the basin lagtime multiple-regression analysis . . . 41

14. Time and discharge ratios of the dimensionless hydrograph .............. 43

15. Computation of simulated hydrograph and integration of flood volume of estimated 100-year peak discharge for an ungaged rural stream in eastern Adams County, Ohio

\section{CONVERSION FACTORS}

$\begin{array}{lll}\text { Multiply } & \text { By } & \text { To obtain }\end{array}$

cubic foot per second

$\begin{array}{lll}\text { inch } & 25.4 & \text { millimeter } \\ \text { foot } & 0.3048 & \text { meter } \\ \text { mile } & 1.609 & \text { kilometer } \\ \text { mile } & 0.1894 & \text { meter per kilometer } \\ \text { inch } & 6.452 & \text { square centimeter } \\ \text { mile } & 2.590 & \text { square kilometer } \\ \text { foot } & 0.02832 & \text { cubic meter } \\ \text { econd } & 0.02832 & \text { cubic meter per second }\end{array}$




\section{GLOSSARY}

The following are definitions of selected symbols as they are used in this report; they are not necessarily the only valid definitions for these symbols.

A Drainage area (in square miles)--The drainage area that contributes surface runoff to a specified location on a stream, measured in a horizontal plane. Computed (by planimeter, digitizer, or grid method) from U.S. Geological Survey 7.5-minute topographic quadrangle maps.

BDF Basin-development factor--A measure of basin development that takes into account channel improvements, impervious channel linings, storm sewers, and curb-and-gutter streets. It is measured on a scale from 0 (little or no development) to 12 (fully developed). See Sherwood (1993) for a more complete description and method of computation.

d Duration of a maximum flood-volume or maximum rainfall event (in hours).

D Duration of a simulated flood hydrograph (in hours).

$\mathrm{dRF}_{\mathrm{T}} \quad \mathrm{d}$-hour $\mathrm{T}$-year rainfall (in inches)--Maximum rainfall having a d-hour duration and $\mathrm{T}$-year recurrence interval. Determined from U.S. Weather Bureau Technical Paper 40 (U.S. Department of Commerce, 1961).

$\mathrm{dV}_{\mathrm{T}} \quad \mathrm{d}$-hour $\mathrm{T}$-year flood volume (in millions of cubic feet)--Maximum flood volume having a d-hour duration and T-year recurrence interval. Computed from frequency analysis of synthetic annual peak-volume data, or estimated from multiple-regression equations presented in this report.

EL Average basin elevation index (in thousands of feet above sea level)--Determined by averaging main-channel elevations at points 10 and 85 percent of the distance from a specified location on the main channel to the topographic divide, as determined from U.S. Geological Survey 7.5-minute topographic quadrangle maps.

F Forested area (in percent)--The percentage of the total drainage area occupied by forest cover, as determined by measuring the green-tinted areas on U.S. Geological Survey 7.5-minute topographic quadrangle maps.

L Main-channel length (in miles)--Distance measured along the main channel from a specified location to the topographic divide, as determined from U.S. Geological Survey 7.5-minute topographic quadrangle maps.

LT Basin lagtime (in hours)--Time elapsed from the centroid of the rainfall excess (rainfall contributing to direct runoff) to the centroid of the resultant runoff hydrograph. LT for urban basins may be estimated from a multiple-regression equation presented in this report.

P Average annual precipitation (in inches)--Determined from Ohio Department of Natural Resources Water Inventory Report No. 28 (Harstine, 1991).

Q Discharge (in cubic feet per second).

$\mathrm{Q}_{\mathrm{p}} \quad$ Peak discharge (in cubic feet per second)--The maximum discharge of an observed or simulated flood hydrograph.

$\mathrm{Q}_{\mathrm{T}} \quad$ Peak discharge of T-year recurrence interval (in cubic feet per second)--The estimated peak discharge of T-year recurrence interval, as computed from multiple-regression equations developed by Koltun and Roberts (1990).

SEP Average standard error of prediction (in percent)--An approximation of the error associated with estimating a streamflow characteristic of a site not used in the regression analysis.

SER Average standard error of regression (in percent)--A measure of the error associated with estimating a streamflow characteristic of a site used in the regression analysis. 
SL Main-channel slope (in feet per mile)--Computed as the difference in elevations (in feet) at points 10 and 85 percent of the distance along the main channel from a specified location on the channel to the topographic divide, divided by the channel distance (in miles) between the two points, as determined from U.S Geological Survey 7.5-minute topographic quadrangle maps.

ST Storage area (in percent)--That part of the contributing drainage area occupied by lakes, ponds, land swamps, as shown on U.S. Geological Survey 7.5-minute topographic quadrangle maps. The storage capacity (current, available, or maximum) of a given lake, pond, or swamp is not a factor when making this measurement.

t Time (in hours).

$\mathrm{T}$ Recurrence interval (in years)--The average interval of time within which a given hydrologic event will be equaled or exceeded once.

$\mathrm{VQ}_{\mathrm{p}} \quad$ Volume of hydrograph having peak discharge $\mathrm{Q}_{\mathrm{p}}$ (in cubic feet)--The total flood volume computed by numerically integrating the total area under a simulated hydrograph with peak discharge $\mathrm{Q}_{\mathrm{p}} . \mathrm{VQ}_{\mathrm{p}}$ may also be directly computed for the Georgia dimensionless hydrograph (Inman, 1987) using an equation presented in this report.

$\mathrm{VQ}_{\mathrm{T}}(\mathrm{t}) \quad$ Cumulative volume at time $\mathrm{t}$ (in cubic feet)--Volume computed by numerically integrating the area of a simulated hydrograph from time zero to time t.

$\mathrm{VQ}_{\mathrm{T}} \quad$ Hydrograph volume of $\mathrm{Q}_{\mathrm{T}}$ (in cubic feet)--The total flood volume computed by integrating the area under a simulated hydrograph having a peak discharge with a $\mathrm{T}$-year recurrence interval $\left(\mathrm{Q}_{\mathrm{T}}\right)$. 


\title{
Estimation of Flood Volumes and Simulation of Flood Hydrographs for Ungaged Small Rural Streams in Ohio
}

\author{
By James M. Sherwood
}

\section{Abstract}

Methods are presented to estimate flood volumes and simulate flood hydrographs of rural streams in Ohio whose drainage areas are less than 6.5 square miles. The methods were developed to assist planners in the design of hydraulic structures for which the temporary storage of water is an important element of the design criteria or where hydrograph routing is required. Examples of how to use the methods also are presented.

Multiple-regression equations were developed to estimate maximum flood volumes of $\mathrm{d}$-hour duration and T-year recurrence interval $\left(\mathrm{dV}_{\mathrm{T}}\right)$. The data base for the analyses includes rainfall-runoff data from 62 small basins distributed throughout Ohio. Maximum annual flood-volume data for each site for all combinations of six durations $(1,2,4,8,16$, and 32 hours $)$ and six recurrence intervals $(2,5,10$, 25,50 , and 100 years) were analyzed. The explanatory variables in the resulting volumeduration-frequency equations are drainage area, average annual precipitation, mainchannel slope, and forested area. Standard errors of prediction for the $d V_{T}$ equations range from \pm 28 percent to \pm 44 percent.

A method is described to simulate flood hydrographs by applying a peak discharge and an estimated basin lagtime to a dimensionless hydrograph. Peak discharge may be estimated from equations in which drainage area, mainchannel slope, and storage area are the significant explanatory variables and average standard errors of prediction range from 33 to

41 percent. An equation was developed to estimate basin lagtime in which main-channel slope, forested area, and storage area are the significant explanatory variables and the aver- age standard error of prediction is \pm 37 percent. A dimensionless hydrograph originally developed for use in Georgia was verified for use in Ohio.

Step-by-step examples show how to (1) simulate flood hydrographs and compute their volumes, and (2) estimate volumeduration-frequency relations of small ungaged rural streams in Ohio. The volumes estimated by the two methods are compared. Both methods yield similar results for volume estimates of short duration, which are applicable to convective-type storm runoff. The volumeduration-frequency equations can be used to compute volume estimates of long and short duration because the equations are based on maximum-annual-volume data of long and short duration. The dimensionless-hydrograph method is based on flood hydrographs of average duration and cannot be used to compute volume estimates of long duration. Volume estimates of long duration may be considerably greater than volume estimates of short duration and are applicable to runoff from frontal-type storms.

\section{INTRODUCTION}

Accurate methods of estimating peak discharges, runoff volumes, and flood hydrographs of small rural streams are required so that a proper balance between inflow, outflow, and storage can be achieved when designing hydraulic structures. Accurate estimates of runoff volumes are particularly important in the design of structures, such as culverts and detention basins, for which temporary storage of water is an important part of the design. In the past, design considerations were generally based on the magnitude of instantaneous peak 
flows with specific recurrence intervals, and floods were allowed to pass through the hydraulic structure with minimal reduction in peak discharge and minimal storage upstream of the structure. Increasingly stringent stormwater-management regulations (Ohio Department of Natural Resources, 1981) and rising construction costs have increased the importance of detention storage as a design consideration. Stormwater-management guidelines require a reduction in peak discharge to lessen the effects of flooding downstream. Or, the cost of a new culvert may be significantly reduced by constructing a smaller diameter culvert if sufficient detention storage can be provided to allow adequate storage during large-volume floods. Accurate estimates of large-volume floods are required for such storage analyses. Bridge engineers in Ohio are in need of methods to estimate the magnitudes and frequencies of maximum flood volumes and shapes of flood hydrographs for small ungaged rural streams in Ohio.

In April 1981, the U.S. Geological Survey, in cooperation with the Ohio Department of Transportation and the U.S. Department of Transportation, Federal Highway Administration, began an 8-year flood-volume study of small rural streams in Ohio.

The objectives of this study were to:

1. Expand the U.S. Geological Survey's data base by collecting continuous streamflow and rainfall data and synthesizing long-term streamflow record at 32 rural sites with drainage areas less than 10 square miles.

2. Develop multiple-regression equations to estimate flood volumes at sites on ungaged small rural streams.

3. Develop a method to simulate flood hydrographs at ungaged sites.
4. Prepare two reports: An interim report (Sherwood, 1985) describing methods of study, site selection, instrumentation, and data collection as well as a preliminary summary of data; and a final report summarizing data collection and analysis and presenting the techniques to estimate flood volumes and simulate flood hydrographs.

\section{Purpose and Scope}

This report summarizes the methods of data collection and analysis for this study and presents the equations developed to estimate flood-volume frequency and basin lagtime. It also presents a method of simulating flood hydrographs by applying estimated basin lagtime and peak discharge to a dimensionless hydrograph. Finally, step-by-step examples are given showing how to use the equations and how to simulate flood hydrographs. The equations and methods developed are applicable to small rural streams in Ohio whose basin characteristics are similar to the basin characteristics of the study sites.

\section{Previous Work and Approach to this Study}

The work of previous investigators was used to evaluate and select the most appropriate approach to use in developing methods of estimating the following three flood characteristics addressed in this study:

1. Peak discharge having a specific interval.--For example, a 25-year flood theoretically would occur an average of once every 25 years or have a 4-percent chance of occurrence in any given year.

2. Flood hydrograph having a specific peak discharge.--For example, the 50-year flood hydrograph is a plot of discharge against time, in which the peak discharge has a 50-year recurrence interval. 
3. Flood volume having a specific duration and recurrence interval.-For example, a 4-hour, 100-year volume is the maximum flood volume during a 4-hour period that theoretically would occur an average of once every 100 years.

\section{Equations developed by Koltun and} Roberts (1990) can be used to estimate peak discharge for rural unregulated streams in Ohio with drainage areas of 0.01 to 7,422 square miles. A technique for simulation of flood hydrographs in which estimated peak discharge and estimated basin lagtime are applied to a dimensionless hydrograph was selected for development in this study. The development of the hydrograph-simulation technique consisted of (1) the use of the equations developed by Koltun and Roberts (1990) to estimate peak discharge, (2) the development of an equation to estimate basin lagtime, and (3) the verification of a previously developed dimensionless hydrograph for use on small rural streams in Ohio.

The estimated peak discharge and corresponding simulated flood hydrograph can provide the necessary inflow information for design situations in which storage is not an important factor. In such situations, only a moderate reduction in peak discharge may be required with little danger of overtopping a roadway embankment or causing serious flooding. Simulated flood hydrographs also provide a means of routing design peak discharges through a hydraulic structure so that outflow peak discharges may be estimated. In situations where the design outflow is required or desired to be considerably less than the design inflow, however, some volume of water must temporarily be stored upstream from the structure. In this case, an estimate of volume for a design duration is needed.
The volume computed by integrating the design discharge hydrograph is frequently used as an estimate of volume. The dimensionless hydrographs used in the simulation of designdischarge hydrographs are usually developed from observed flood hydrographs having relatively high peak discharges and average durations. Consequently, when a flood hydrograph is simulated by use of a dimensionless hydrograph, the result is a more sharply crested, average-duration hydrograph with volume lower than that of a hydrograph having the same peak discharge but much longer duration. Furthermore, the actual shape of the hydrograph becomes less important in the design of a structure such as a detention basin having a relatively small outlet and large storage capacity. It is more important to estimate the volume of inflow for several durations to develop a relation between inflow volume and time. This relation, in combination with an estimate of the relation between outflow volume and time, can be used to develop an estimate of the relation between the required storage and time.

The approach used in synthesizing hydrographs and volumes is similar to that used by Craig and Rankl (1978) in Wyoming; Becker (1980) in South Dakota; and Franklin (1984) in Florida. In those studies, the U.S. Geological Survey hydrograph synthesis program E784 was used to synthesize long-term (60- to 75-year) hydrograph records from longterm rainfall and evaporation records by use of a calibrated rainfall-runoff model (program A634). These programs are described by Carrigan and others (1977).

Program E784 computes discharges for up to five of the largest storms for each year on the basis of daily rainfall totals. The logarithms of the annual peak discharges and their associated volumes from this data set are each fitted by a Pearson Type III frequency distribution. 
For this study, the program was modified to scan the long-term synthetic-hydrograph (discharge) data for each station and compute the largest runoff volume for each of six durations $(1,2,4,8,16$, and 32 hours) for each water year ${ }^{1}$ of synthetic-discharge data. These six values are not necessarily computed from the same runoff event. The modifications were made to address the following shortcomings in E784 in regard to analysis of volume data:

1. Program E784 uses the volumes associated with the annual peak discharges for the volume-frequency analysis rather than allowing for ranking and selection by maximum volumes.

2. The volume-frequency relation developed by use of program E784 is not associated with a specific duration, which limits the applicability of the relation.

The modified program then computes logarithms of the annual peak volumes for each duration and fits them by a Pearson Type III frequency distribution. These data, for each station, can then be used to develop multipleregression equations to estimate flood volume as a function of duration and recurrence interval.

\section{Acknowledgments}

The author thanks the Ohio Department of Transportation and the U.S. Department of Transportation, Federal Highway Administration, for their support and cooperation through

${ }^{\mathbf{1}}$ Water year in U.S. Geological Survey reports dealing with surface-water supply is the 12 -month period October 1 through September 30. The water year is designated by the calendar year in which it ends. Thus, the year ending September 30, 1980, is called the "1980 water year." out the project. The cooperation of property owners who permitted the collection of data on their property is also greatly appreciated.

\section{DATA COLLECTION}

A review of data collected previously in Ohio showed that complete hydrograph records were generally not available for small rural streams. Most of the data collected on small rural streams were from crest-stage gages, which record flood peaks only. A data collection network of 32 small rural streams was established (fig. 1, table 1). Rainfall and runoff data were collected at 5-minute intervals for 5 years (except during winter) at the 32 rural streams whose drainage areas ranged from 0.13 to 6.45 square miles. These data were used to calibrate a rainfall-runoff model for each site. Rainfall and runoff data and calibrated rainfall-runoff models from a prior study were available for 30 urban sites (fig. 2, table 2).

Synthesized volume data from all 62 rural and urban sites were used for the volumeduration-frequency analyses. Flood volumes generally are not as affected by urbanization as are peak discharges, basin lagtimes, and shapes of flood hydrographs. The rates of runoff may be greatly increased due to urbanization because of the effect of decreased roughness on overland and in channel flow velocities. The volumes of runoff also may be increased but generally to a lesser extent than the increase in rates of runoff. The increase in volumes of runoff is a result of increased impervious areas (decreased infiltration) that coincide with urbanization. The effects of urbanization on flood volumes are diminished for large floods of long duration. For large floods of long duration, soils become saturated (reducing infiltration rates), minimizing the relative influence of impervious areas on flood volumes. Consequently, it was considered reasonable to merge the synthesized volume data

\section{Estimation of Flood Volumes and Simulation of Flood Hydrographs for Ungaged Small Rural Streams in Ohio}




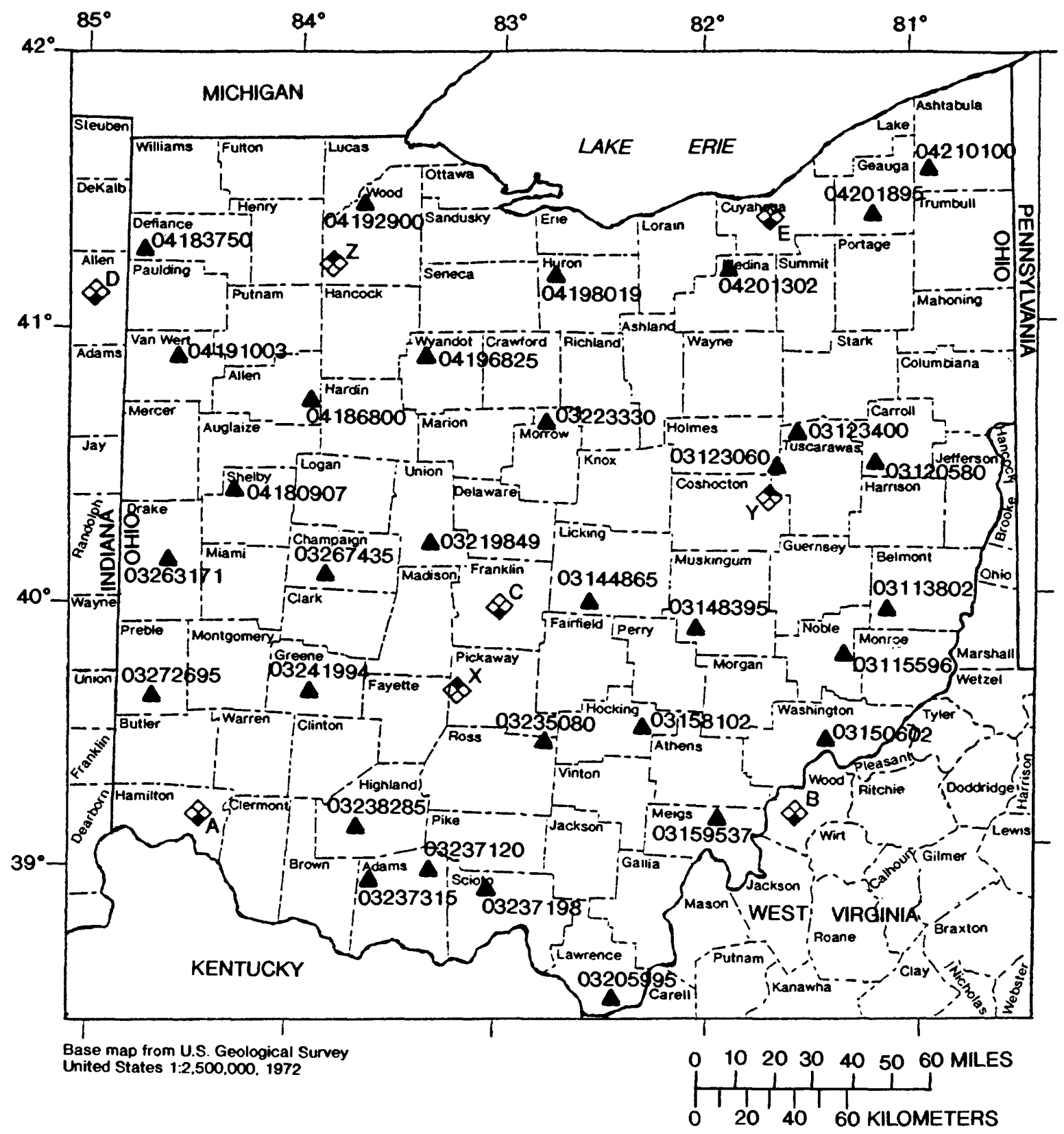

EXPLANATION

$\triangle 04192900$ U.S. GEOLOGICAL SURVEY RAINFALL-RUNOFF STATION AND NUMBER $8 x$ NATIONAL WEATHER SERVICE LONG-TERM RAINFALL STATION AND IDENTIFIER NATIONAL WEATHER SERVICE EVAPORATION STATION AND IDENTIFIER

Figure 1.--Approximate locations of rural rainfall-runoff stations, long-term rainfall stations, and evaporation stations. (See tables 1,5, and 6 for cross-reference to station numbers and identifiers.) 
Table 1. Station numbers, station names, latitudes, and longitudes of 32 rural study sites in Ohio

\begin{tabular}{|c|c|c|c|}
\hline $\begin{array}{l}\text { Station } \\
\text { number }\end{array}$ & Station name & $\begin{array}{l}\text { Lati- } \\
\text { tude }\end{array}$ & $\begin{array}{l}\text { Longi- } \\
\text { tude }\end{array}$ \\
\hline
\end{tabular}

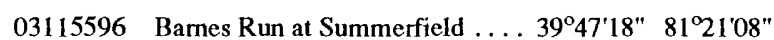

04196825 Browns Run near Crawford .... 40 4053'13" 83º $20^{\prime} 15^{\prime \prime}$

03235080 Bull Creek near Adelphi ...... 39 3927'11" 82 46 $46^{\prime \prime}$

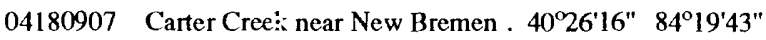

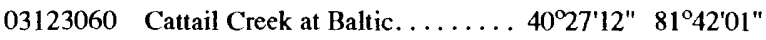

03113802 Chestnut Creek near Bamesville. 39 $566^{\prime} 50^{\prime \prime} 81^{\circ} 09^{\prime} 25^{\prime \prime}$

03148395 Claypit Creek near Roseville .. . 39 ${ }^{\circ} 50^{\prime 2} 28^{\prime \prime} 8^{\circ} 04^{\prime} 15^{\prime \prime}$

04201302 Delwood Run at Valley City .. 4 41 ${ }^{\circ} 14^{\prime} 15^{\prime \prime} 81^{\circ} 55^{\prime} 18^{\prime \prime}$

$03237198 \begin{gathered}\text { Duncan Hollow Creek near } \\ \text { McDermott } \ldots \ldots \ldots \ldots \ldots 38^{\circ} 52^{\prime 2} 29^{\prime \prime} 83^{\circ} 03^{\prime} 37^{\prime \prime}\end{gathered}$

03123400 Dundee Creek at Dundee ... . . 40 40 35'35" 81 $36^{\prime} 13^{\prime \prime}$

03237315 Elk Fork at Winchester ..... 38 56 $56^{\prime 4} 49^{\prime \prime} 8^{\circ} 37^{\prime} 21^{\prime \prime}$

03159537 Elk Run near Alfred ....... 39 39 $09^{\prime} 41^{\prime \prime}$ 81 ${ }^{\circ} 57^{\prime} 47^{\prime \prime}$

03120580 Falling Branch at Sherrodsville . 40 $300^{\prime} 28^{\prime \prime} 81^{\circ} 1425^{\prime \prime}$

04201895 Fire Run at Auburn Comers ... . 41 ${ }^{\circ} 23^{\prime} 36^{\prime \prime} \quad 81^{\circ} 12^{\prime} 56^{\prime \prime}$

03263171 Harte Run near Greenville ... . 40 40 $08^{\prime} 41^{\prime \prime} 84^{\circ} 36^{\prime} 41^{\prime \prime}$

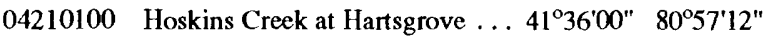

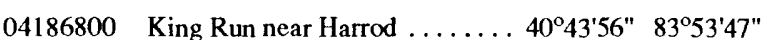

03267435 Kitty Creek at Terre Haute ... 40 4003'09" $83^{\circ} 52^{\prime} 57^{\prime \prime}$

03223330 March Run near West Point ... 4 40³7'55" 82 $42^{\circ}$ '56"

04183750 Racetrack Run at Hicksville .. 4 $41^{\circ} 18^{\circ} 58^{\prime \prime} \quad 84^{\circ} 46^{\circ} 00^{\prime \prime}$

04192900 Reitz Run at Waterville ...... 41 $21^{\circ} 9^{\prime} 50^{\prime \prime} 83^{\circ} 42^{\prime} 35^{\prime \prime}$

04198019 Sandhill Creek near Monroeville............ 41 ${ }^{\circ} 12^{\prime} 13^{\prime \prime} 82^{\circ} 42^{\prime} 56^{\prime \prime}$

03205995 Sandusky Creek near Burlington ............ 38 $28^{\circ} 03^{\prime \prime} 82^{\circ} 30^{\prime} 36^{\prime \prime}$

03150602 Second Creek near Marietta .. 39 37'36" 81'26'24"

03144865 Slim Creek at Kirkersville ... 39 39 $56^{\prime} 51^{\prime \prime} 8^{\circ} 36^{\prime} 13^{\prime \prime}$

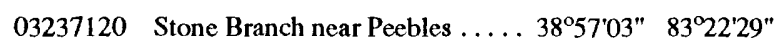

04191003 Stripe Creek near Van Wert ... 40 40 54'29" 84º33'43"

03238285 Sugar Run near New Market .. 39 39 $06^{\prime} 30^{\prime \prime} 83^{\circ} 40^{\prime} 36^{\prime \prime}$

03219849 Tombstone Creek near

Marysville ........... 40 40 $12^{\prime} 42^{\prime \prime} 83^{\circ} 18^{\prime} 15^{\prime \prime}$

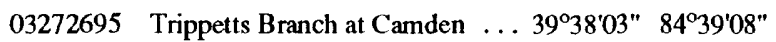

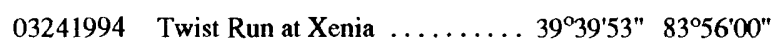

03158102 Wolfkiln Run at Haydenville .. 39 $28^{\circ} 35^{\prime \prime} 8^{\circ} 18^{\prime} 51^{\prime \prime}$
Table 2. Station numbers, station names, latitudes and longitudes of 30 urban study sites in Ohio

\begin{tabular}{ll}
\hline Station & Lati- \\
number & Longi- \\
tude & tude
\end{tabular}

03258520 Amberly Ditch near Cincinnati . $39^{\circ} 11^{\prime} 31^{\prime \prime} 84^{\circ} 25^{\prime} 44^{\prime \prime}$

03238790 Anderson Ditch at Cincinnati . . 39 $04^{\prime} 14^{\prime \prime} 84^{\circ} 22^{\prime} 51^{\prime \prime}$

03098900 Bunn Brook at Struthers . . . . 41 $1^{\circ} 03^{\prime} 05^{\prime \prime} 80^{\circ} 36^{\prime} 28^{\prime \prime}$

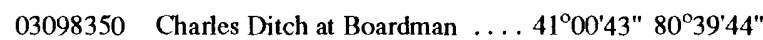

03236050 Coalton Ditch at Coalton .... 39 $09^{\circ} 36^{\prime \prime} 82^{\circ} 36^{\prime} 44^{\prime \prime}$

03228950 Dawnlight Ditch at Columbus . . 40 00'51" 82 $56^{\circ} 46^{\prime \prime}$

03260095 Delhi Ditch near Cincinnati .. 39 $0548^{\prime \prime} 84^{\circ} 37^{\prime} 23^{\prime \prime}$

04208640 Dugway Brook at Cleveland Heights . . . . . . . . . 4 41 $30^{\circ} 35^{\prime \prime} 81^{\circ} 34^{\prime} 06^{\prime \prime}$

04208680 Euclid Creek Tributary at Lyndhurst ..........441 $31^{\circ} 52^{\prime \prime} 81^{\circ} 30^{\prime} 14^{\prime \prime}$

03221450 Fishinger Creek at Upper

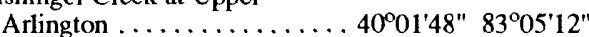

03226900 Fishinger Road Creek at Upper Arlington .......... 40. $00^{\circ} 25^{\prime \prime} 83^{\circ} 02^{\prime} 40^{\prime \prime}$

03241850 Gentile Ditch at Kettering . . . 3 39 $42^{\prime} 47^{\prime \prime} 84^{\circ} 08^{\prime} 56^{\prime \prime}$

04200800 Glen Park Creek at Bay Village . 41 $299^{\prime} 09^{\prime \prime} 81^{\circ} 54^{\prime} 46^{\prime \prime}$

04193900 Grassy Creek at Perrysburg . . 41 $31^{\circ} 20^{\prime \prime} 83^{\circ} 36^{\prime} 45^{\prime \prime}$

03159503 Home Ditch at Athens . . . . . 39 $29^{\circ} 06^{\prime \prime} 82^{\circ} 04^{\prime} 43^{\prime \prime}$

04176870 Ketchum Ditch at Toledo . . . . 41 41 $42^{\prime} 39^{\prime \prime} 83^{\circ} 35^{\prime} 45^{\prime \prime}$

04208685 Mall Run at Richmond Heights . $41^{\circ} 32^{\prime} 35^{\prime \prime} 81^{\circ} 29^{\prime} 54^{\prime \prime}$

03227050 Norman Ditch at Columbus . . . 39 3959'35" $83^{\circ} 02^{\prime} 02^{\prime \prime}$

04208580 North Fork Doan Brook at

Shaker Heights ....... 41 $28^{\circ} 57^{\prime \prime} 81^{\circ} 32^{\prime} 34^{\prime \prime}$

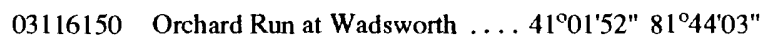

$04187700 \quad$ Pike Run at Lima . . . . . . . 40 40 46 $06^{\circ} 84^{\circ} 06^{\prime} 57^{\prime \prime}$

03115810 Rand Run at Marietta . . . . . . 39 $24^{\circ} 48^{\prime \prime} 81^{\circ} 25^{\prime} 44^{\prime \prime}$

03226860 Rush Run at Worthington. . . . . 40 $05^{\circ} 41^{\prime \prime} 82^{\circ} 59^{\prime} 56^{\prime \prime}$

04176880 Silver Creek at Toledo ... . . . 41 42 $42^{\prime} 58^{\prime \prime} 83^{\circ} 35^{\prime} 08^{\prime \prime}$

03256250 Springfield Ditch near Cincinnati. .......... 39 $9^{\circ} 13^{\prime} 48^{\prime \prime} 84^{\circ} 31^{\prime} 16^{\prime \prime}$

03115995 Sweet Henri Ditch at Norton ... 41 ${ }^{\circ} 01^{\prime} 27^{\prime \prime} 81^{\circ} 38^{\prime} 13^{\prime \prime}$

04176890 Tifft Ditch at Toledo ...... 41 4 $41^{\prime} 55^{\prime \prime} 83^{\circ} 37^{\prime} 53^{\prime \prime}$

04207110 Tinkers Creek Tributary at

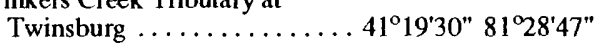

03271295 Whipps Ditch near Centerville . 39 $39^{\prime} 18^{\prime \prime} 84^{\circ} 10^{\prime} 10^{\prime \prime}$ 03259050 Wyoming Ditch at Wyoming . . 39 $14^{\circ} 00^{\prime \prime} 84^{\circ} 29^{\prime} 26^{\prime \prime}$ 


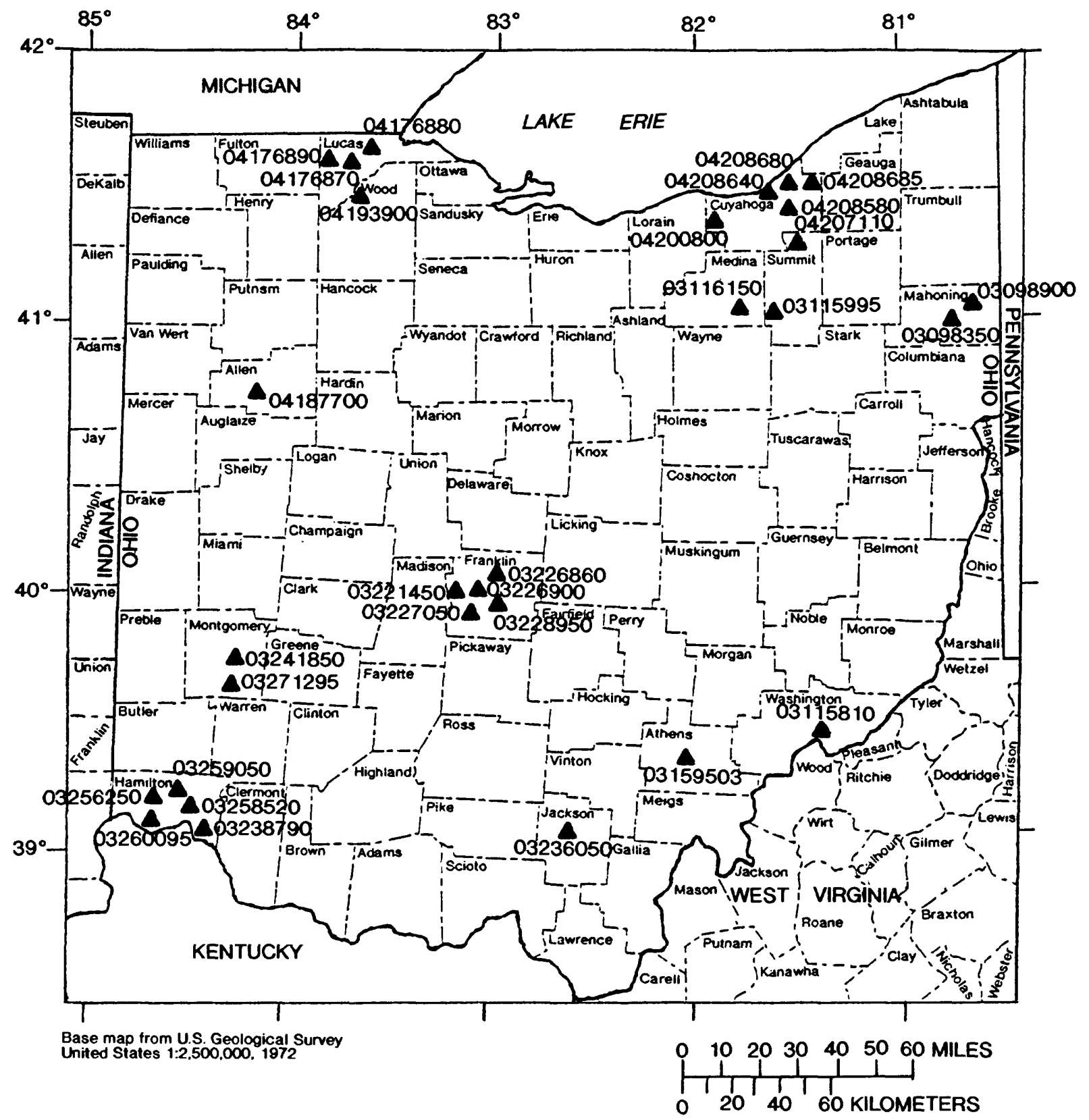

EXPLANATION

03098900 U.S. GEOLOGICAL SURVEY RAINFALL-RUNOFF STATION AND NUMBER

Figure 2.--Approximate locations of urban rainfall-runoff stations. (See table 2 for geographical coordinates.) 
from all 62 rural and urban sites for the volume-duration-frequency multipleregression analyses with an urbanization indicator variable to account for the effects of urbanization on runoff volumes of short duration. Because of the significant effects of urbanization on rates of runoff, however, only observed hydrograph data from the 32 rural sites were used in the dimensionless hydrograph verification and basin lagtime analyses. This is consistent with only observed rural data being used in the development of the peak discharge equations (Koltun and Roberts, 1990).

The following sections describe the datacollection methods for the 32 rural study sites. The data-collection methods for the 30 urban study sites are very similar and are described in Sherwood (1993).

\section{Site Reconnaissance and Selection}

One of the most important phases of this study was reconnaissance and selection of the 32 rural sites. Two broad categories of characteristics controlled and guided the selection process: (1) physical and hydraulic characteristics of the potential streamflow-gaging location, which influence the quality of data that can be collected, and (2) basin characteristics, which influence runoff processes. A wide range of basin characteristics was desired to ensure general applicability of the statewide regression models this study proposed to develop. Basins also were required to have less than 5-percent storage area (see ST in glossary) because this variable was not to be included in the regression analyses.

Logistical limitations prevented the definition of stage-discharge relations entirely by means of current-meter measurements.

Therefore, only sites where a reliable theoretical culvert rating could be established were considered.
The factors that control the reliability of theoretical stage-discharge relations at culverts include uniformity of slope, size, shape, and material of the culvert; absence of debris in culvert barrel; infrequent road overflow; standard inlet conditions; straight and unobstructed approach; and adequate slope and conveyance downstream to prevent backwater problems. These factors were checked at each potential site, and only those sites that appeared to meet these criteria were considered.

The size of the culvert with respect to the channel width also was taken into consideration. A culvert that is smaller than the channel width will contract flow as the stream enters the culvert. Such contraction provides for a more sensitive and accurate stagedischarge relation. In contrast, a culvert that is very small with respect to the channel width can cause a significant amount of flow to be temporarily stored upstream from the culvert embankment, which results in an attenuation of the outflow hydrograph (measured) as compared to the inflow hydrograph.

A total of 111 active and discontinued crest-stage-gage sites were screened for acceptability because most of the physical and hydraulic characteristics and basin characteristics were already documented; eight of these sites were selected. Map and field reconnaissance were used to select the 24 additional sites on the basis of the criteria discussed previously. About 7,000 sites were initially identified on 7.5-minute topographic maps and field checked. Culvert dimensions and other site information were recorded in field notes, and drainage areas were computed for 344 of these sites. About 240 sites met the criteria; from these, the selection of the 24 additional stations was made. The locations of the 32 rural study sites are shown in figure 1. 


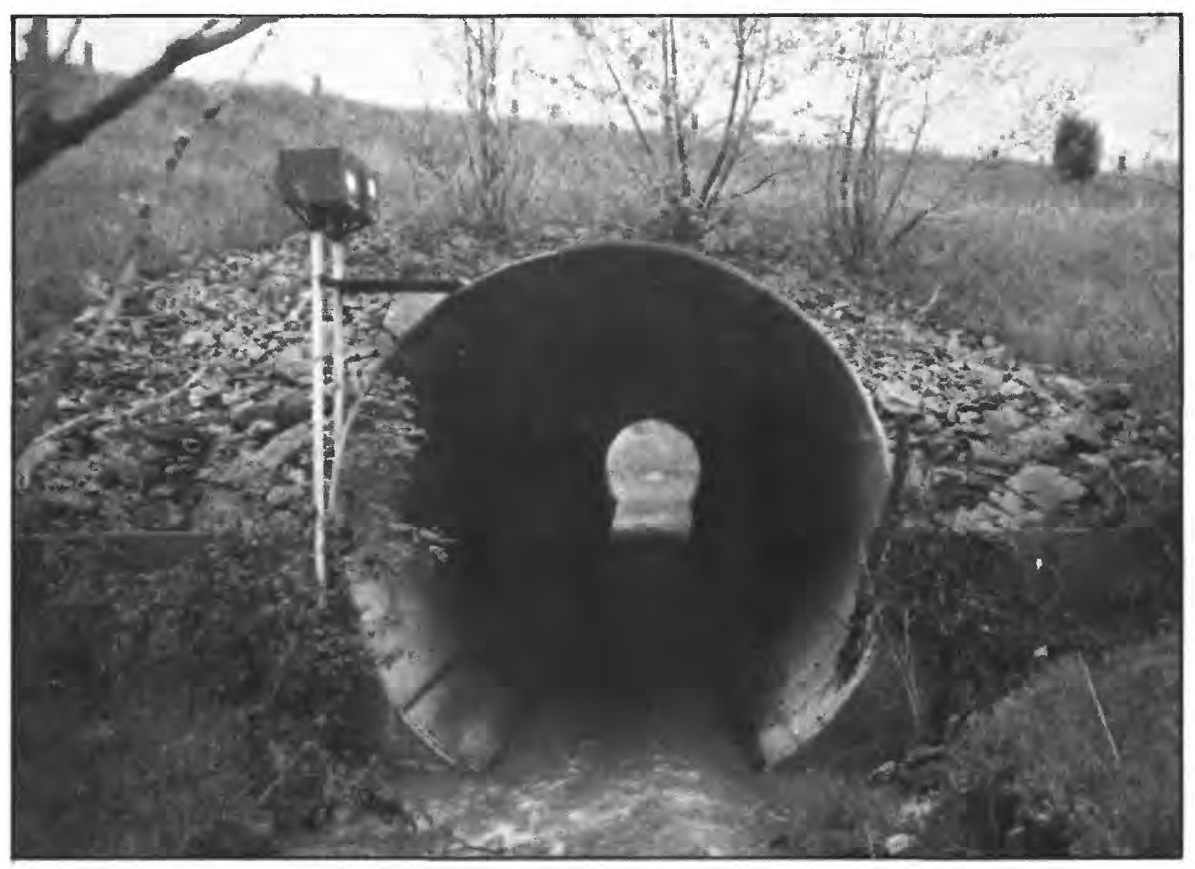

Figure 3.--Typical rainfall-runoff data-collection station, located on Elk Fork near Winchester, Ohio.

\section{Instrumentation of Rainfall-Runoff Gaging Stations}

Stage at each site was sensed by a floatcounterweight mechanism in a stilling well and was recorded by digital recorders. Data from a crest-stage gage mounted at the downstream end of the culvert were used to verify that there was no backwater at the culvert outlet. Downstream stage recorders were necessary at 2 of the 32 sites because of backwater. Stagedischarge relations were developed for each site by use of procedures outlined by Bodhaine (1968), in which discharges for a full range of stages are computed indirectly by application of continuity equations and energy equations. The physical properties of the culverts at the 32 sites are summarized in table 3 .
Rainfall at each site was recorded by another digital recorder housed in a similar steel shelter with a 50-square-inch rainfall collector on top. The shelter was mounted on a 3-inch-diameter aluminum float well. A drain tube inside the shelter conveyed collected rain from the collector to the float well. The rain gage was installed at the streamflow-gaging station if the rainfall would not be intercepted by surrounding trees. Otherwise, the rain gage was installed at an unobstructed, accessible location elsewhere within the basin. (A photograph of a typical rainfall-runoff data-collection station is shown in figure 3.) 
Table 3. Physical characteristics of the culverts at 32 rural study sites in Ohio [ft, feet; elev, elevation]

\begin{tabular}{|c|c|c|c|c|c|c|c|c|c|c|c|c|}
\hline $\begin{array}{l}\text { Station } \\
\text { number }\end{array}$ & Stream nam & & $\begin{array}{l}\text { 'Mate- } \\
\text { rial }\end{array}$ & ${ }^{2}$ Shape & $\begin{array}{c}\text { Height } \\
\text { (ft) }\end{array}$ & $\begin{array}{l}\text { Width } \\
\text { (ft) }\end{array}$ & $\begin{array}{l}\text { Length } \\
\text { (ft) }\end{array}$ & $\begin{array}{l}{ }^{3} \text { Up } \\
\text { stream } \\
\text { invert } \\
\text { elev. } \\
\text { (ft) }\end{array}$ & $\begin{array}{l}{ }^{3} \text { Down- } \\
\text { stream } \\
\text { invert } \\
\text { elev. } \\
\text { (ft) }\end{array}$ & ${ }^{4}$ Fall & $\begin{array}{l}\text { Slope } \\
(\mathrm{ft} / \mathrm{ft})\end{array}$ & $\begin{array}{l}\text { Manning } \\
\text { rough- } \\
\text { ness } \\
\text { coeffi- } \\
\text { cient }\end{array}$ \\
\hline 03115596 & Bames Run & 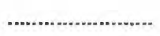 & $\mathrm{CM}$ & $\mathrm{C}$ & 9.02 & 9.02 & 166.40 & 10.00 & 7.58 & 2.42 & .015 & .032 \\
\hline 04196825 & Browns Run & ........................... & $\mathrm{RC}$ & $\mathrm{C}$ & 7.93 & 7.93 & 195.80 & 10.00 & 9.76 & .24 & .001 & .015 \\
\hline 03235080 & Bull Creek & 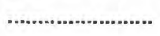 & $\mathrm{CM}$ & $\mathrm{C}$ & 14.00 & 14.00 & 154.10 & 64.18 & 63.66 & .52 & .003 & .030 \\
\hline 04180907 & Carter Creek & 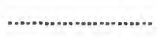 & $\mathrm{RC}$ & B & 5.02 & 6.02 & 52.50 & 10.00 & 9.73 & .27 & .005 & .015 \\
\hline 03123060 & Cattail Creek & 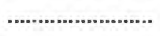 & $\mathrm{RC}$ & B & 2.52 & 4.00 & 27.00 & 10.00 & 9.88 & .12 & .004 & .015 \\
\hline 03113802 & Chestnut Creek & 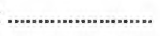 & $\mathrm{RC}$ & B & 3.02 & 4.01 & 34.00 & 10.00 & 8.74 & 1.26 & .037 & .013 \\
\hline 03148395 & Claypit Creek & 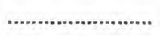 & $\mathrm{CM}$ & $\mathrm{C}$ & 8.05 & 8.05 & 361.90 & 10.00 & 8.77 & 1.23 & .003 & .033 \\
\hline 04201302 & Delwood Run & ....................... & $\mathrm{RC}$ & $\mathrm{C}$ & 5.00 & 5.00 & 154.10 & 10.00 & 6.14 & 3.86 & .025 & .015 \\
\hline 03237198 & Duncan Hollow & v Creek ............... & $\mathrm{CM}$ & C & 6.96 & 6.96 & 287.10 & 10.00 & 4.41 & 5.59 & .019 & .033 \\
\hline 03123400 & Dundee Creek & . & RC & $\mathrm{C}$ & 5.04 & 5.04 & 124.00 & 18.07 & 16.26 & 1.81 & .015 & .013 \\
\hline 03237315 & Elk Fork & 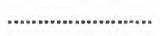 & $\mathrm{CM}$ & $\mathrm{C}$ & 15.13 & 15.13 & 202.30 & 10.00 & 7.59 & 2.41 & .012 & .030 \\
\hline 03159537 & Elk Run & (... & $\mathrm{CM}$ & A & 5.30 & 7.17 & 68.60 & 10.00 & 9.21 & .79 & .012 & .034 \\
\hline 03120580 & Falling Branch & 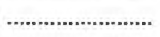 & $\mathrm{RC}$ & B & 3.04 & 5.03 & 32.40 & 10.00 & 9.71 & .29 & .009 & .013 \\
\hline 04201895 & Fire Run & ................... & $\mathrm{RC}$ & B & 4.00 & 4.03 & 42.15 & 10.00 & 9.23 & .77 & .018 & .018 \\
\hline 03263171 & Harte Run & ..................... & $\mathbf{R C}$ & $\mathrm{C}$ & 7.00 & 7.00 & 185.60 & 10.00 & 9.16 & .84 & .005 & .015 \\
\hline 04210100 & Hoskins Creek & 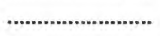 & $\mathrm{CM}$ & A & 10.11 & 16.56 & 59.92 & 4.97 & 3.75 & 1.22 & .020 & .030 \\
\hline 04186800 & King Run & 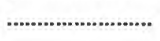 & $\mathrm{CM}$ & A & 5.40 & 7.15 & 98.70 & 17.40 & 16.86 & .54 & .005 & .033 \\
\hline 03267435 & Kitty Creek & 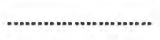 & $\mathrm{CM}$ & A & 8.94 & 14.26 & 84.45 & 10.00 & 8.63 & 1.37 & .016 & .031 \\
\hline 03223330 & March Run & 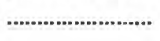 & $\mathrm{CM}$ & C & 5.93 & 5.93 & 80.30 & 10.00 & 8.50 & 1.50 & .019 & .034 \\
\hline 04183750 & Racetrack Run & 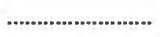 & $\mathrm{VC}$ & $\mathrm{C}$ & 3.00 & 3.00 & 38.00 & 10.00 & 8.92 & 1.08 & .028 & .013 \\
\hline 04192900 & Reitz Run & 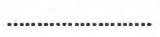 & $\mathrm{RC}$ & $\mathrm{C}$ & 6.98 & 6.98 & 187.60 & 16.52 & 10.82 & 5.70 & .030 & .015 \\
\hline 04198019 & Sandhill Creek & 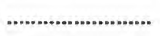 & $\mathrm{CM}$ & A & 5.97 & 8.82 & 97.25 & 10.00 & 9.25 & .75 & .008 & .033 \\
\hline 03205995 & Sandusky Creek & k & $\mathrm{RC}$ & $\mathrm{C}$ & 5.52 & 5.52 & 266.00 & 10.00 & 7.06 & 2.94 & .011 & .013 \\
\hline 03150602 & Second Creek & . & $\mathrm{RC}$ & $\mathrm{C}$ & 9.00 & 9.00 & 189.60 & 10.00 & 8.83 & 1.17 & .006 & .013 \\
\hline 03144865 & Slim Creek & ........................... & $\mathrm{RC}$ & C & 4.01 & 4.01 & 115.40 & 10.00 & 8.17 & 1.83 & .016 & .013 \\
\hline 03237120 & Stone Branch & ........................ & RC & $\mathrm{C}$ & 7.00 & 7.00 & 306.60 & 10.00 & 4.89 & 5.11 & .017 & .013 \\
\hline 04191003 & Stripe Creek & .......................... & $\mathrm{RC}$ & $\mathrm{C}$ & 5.04 & 5.04 & 128.85 & 10.00 & 9.37 & .63 & .005 & .015 \\
\hline 03238285 & Sugar Run & ...................... & $\mathrm{RC}$ & $\mathrm{C}$ & 9.05 & 9.05 & 132.50 & 10.00 & 9.27 & .73 & .006 & .013 \\
\hline 03219849 & Tombstone Cree & ek........................ & $\mathrm{CM}$ & A & 9.86 & 16.67 & 258.10 & 10.00 & 9.29 & .71 & .003 & .031 \\
\hline 03272695 & Trippetts Brancl & h & $\mathrm{RC}$ & $\mathrm{C}$ & 4.50 & 4.50 & 144.70 & 10.00 & 8.29 & 1.71 & .012 & .015 \\
\hline 03241994 & Twist Run & 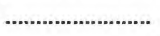 & $\mathrm{CM}$ & C & 7.91 & 7.91 & 94.35 & 10.00 & 8.92 & 1.08 & .011 & .033 \\
\hline 03158102 & Wolfkiln Run & 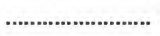 & $\mathrm{RC}$ & $\mathrm{C}$ & 5.87 & 5.87 & 117.00 & 10.00 & 8.42 & 1.58 & .014 & .013 \\
\hline
\end{tabular}

${ }^{1}$ Material

CM - corrugated metal

RC - reinforced concrete

VC - vitrified clay

${ }^{2}$ Shape

$$
\begin{aligned}
& \text { A - arch } \\
& \text { B - box } \\
& \text { C - circle }
\end{aligned}
$$

${ }^{3}$ Elevations above arbitrary datum

${ }^{4}$ Fall - upstream invert elevation minus downstream invert elevation, in feet 


\section{Collection and Storage of Data}

Total daily rainfall data were stored in USGS computer files for all days, and 5-minute rainfall and discharge data were stored for all flood events. If periods of daily rainfall data were missing because of equipment failure or because the recorder was shut down during the winter (mid-December to mid-March), data from a nearby rainfall station operated by the National Weather Service were substituted. The rainfall-runoff model requires continuous daily rainfall data to calculate soil moisture conditions antecedent to storm events.

Data collection was discontinued during the winter because the rain gages were not capable of recording snow accumulations, the rainfall-runoff model used is not capable of simulating snowmelt runoff, and the stagedischarge relations were valid only for unobstructed, ice-free culvert flow. Because most of the storms that produce large floods on small streams occur during the spring, summer, and autumn in Ohio, the loss of usable rainfallrunoff data resulting from the winter shutdown was minimal.

Current-meter measurements of discharge were made at all stations during regular site visits to better define the stage-discharge relations at low to medium discharges. Measurements were made at higher flows whenever possible to confirm or modify the stage-discharge relations at medium to high flows.

Additional data required for model calibration and long-term (80-year) streamflow synthesis are daily pan evaporation, long-term 5-minute rainfall for selected storm periods, and long-term daily rainfall. These data were obtained from eight National Weather Service stations (fig. 1).

All data were stored in the U.S. Geological Survey's WATSTORE system (National WATer Data STOrage and REtrieval System) (Hutchinson, 1975).

\section{Analysis of Detention Storage}

The stage-discharge relation developed for each streamflow station is, more specifically, the relation between the stage (height of water in the stream) at the approach section (approximately one culvert width upstream from the culvert entrance) and the discharge (streamflow) through the culvert. If sufficient ponding occurs upstream from the culvert during large floods, the peak discharge through the culvert may be significantly less than the peak discharge into the pond. The effects of detention storage were analyzed at each site. The peak discharge of record was divided by the cross-sectional area of the channel at the approach section for that discharge. This value is equal to the mean velocity at the approach section and is considered in this analysis to be an indicator of storage. A low approach velocity is considered to correspond to a greater potential for the occurrence of detention storage.

The three sites with the lowest approachsection velocities were selected for further analysis. An upstream-downstream reservoir routing procedure (program A697) documented by Jennings (1977) was applied to the largest observed hydrographs at each of the three sites. A contour map was prepared for each site from field surveys, and elevation-outflow-storage relations were tabulated. The routing program computes an inflow hydrograph on the basis of the outflow hydrograph (observed hydrograph) and the elevationoutflow-storage relations. The average error in peak discharge between the outflow and inflow hydrographs was -1.7 percent for the 13 hydrographs tested, and the maximum error was -3.8 percent. Outflow and inflow hydrographs for one of the 13 hydrographs for which the error was -1.2 percent are shown in figure 4 . Keeping in mind that these were the largest hydrographs from, potentially, the three "worst" sites, the results indicate that, for the 
32 study sites, the effects of detention storage at the gage site on peak discharge and volumes of all durations are negligible.

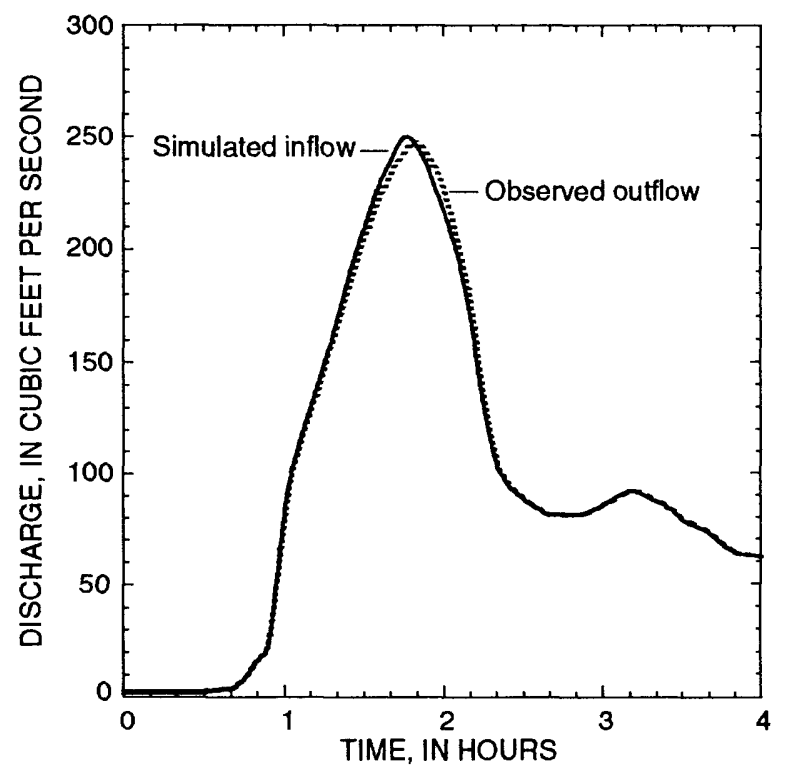

Figure 4.--Simulated inflow hydrograph and observed outflow hydrograph for flood event of April 30, 1983, for Trippetts Branch at Camden, Ohio.

\section{ANALYSIS OF FLOOD VOLUMES AT STREAMFLOW-GAGING STATIONS}

The following sections on model calibration, hydrograph synthesis, and volumeduration-frequency analysis refer to and briefly describe several computer programs. Documentation on the operation of the programs is contained in a user's guide by Carrigan and others (1977).

\section{Calibration of the Rainfall-Runoff Model}

Calibrated rainfall-runoff models frequently are used to synthesize long-term runoff records from long-term rainfall records. Synthesis of record significantly shortens the datacollection period required for flood-frequency analysis.
The U.S. Geological Survey rainfall-runoff model (computer program A634) used for this study was originally developed by Dawdy and others (1972), and was refined by Carrigan (1973), Boning (1974), and Carrigan and others (1977). Model A634 was selected over other rainfall-runoff models because it is reliable and is less costly and time-consuming in terms of data requirements and model calibration. Input data required for model calibration are daily rainfall, daily evaporation, unit ${ }^{2}$ rainfall, and unit discharge. Ten parameters within the model interact to permit simulation of antecedent soil moisture, infiltration, and surfacerunoff routing (table 4 ). The process of adjusting the parameter values in order to achieve a good fit of simulated to observed hydrographs is called calibration.

Maximum and minimum values were set for each of the 10 parameters. Then, within these ranges of values, the parameters were optimized by use of an automatic trial-anderror optimization routine based on a method devised by Rosenbrock (1960). All events were used in the initial calibration.

After initial calibration, selected rainfallrunoff events were excluded from further calibrations on the basis of the following criteria:

1. Many small events were excluded from model calibration to achieve a more even distribution of small and large events. This was accomplished by excluding most events below a specified minimum peak-discharge threshold. Inclusion of too many small events would give too much weight to small events in the calibration process. This was not desirable because the calibrated models would be used to synthesize relatively large events.

${ }^{2}$ Unit data" is a term used by the U.S. Geological Survey that refers to data with a shorter-than-one-day record internal, such as 5-minute, 30-minute, or 3-hour. 
Table 4. Rainfall runoff model parameters

[Dash in units column indicates dimensionless parameter]

\begin{tabular}{l}
$\begin{array}{l}\text { Param- Units Definition } \\
\text { eter }\end{array}$ \\
\hline
\end{tabular}

Antecedent soil-moisture accounting component

\begin{tabular}{lcl}
\hline BMSM & inches & $\begin{array}{l}\text { Soil moisture storage volume at field } \\
\text { capacity. }\end{array}$ \\
EVC & -- & $\begin{array}{l}\text { Coefficient to convert pan evapor- } \\
\text { ation to potential evapotranspiration. }\end{array}$ \\
RR & -- & $\begin{array}{l}\text { Proportion of daily rainfall that } \\
\text { infiltrates the soil. }\end{array}$ \\
DRN & inches per & $\begin{array}{l}\text { The constant rate of drainage for } \\
\text { redistribution of soil moisture }\end{array}$ \\
\hline
\end{tabular}

\section{Infiltration component}

$\begin{array}{cll}\text { PSP } & \text { inches } & \begin{array}{l}\text { Minimum value of the combined } \\ \text { action of capillary suction and soil } \\ \text { moisture differential. }\end{array} \\ \text { KSAT } & \begin{array}{l}\text { inches } \\ \text { per hour }\end{array} & \begin{array}{l}\text { Minimum saturated hydraulic con- } \\ \text { ductivity used to determine soil } \\ \text { infiltration rates. }\end{array} \\ \text { RGF } & -- & \begin{array}{l}\text { Ratio of combined action of suction } \\ \text { and potential at wilting point to that } \\ \text { at field capacity. }\end{array}\end{array}$

\section{Surface-runoff routing component}

\begin{tabular}{lll} 
KSW & hours & Linear reservoir routing coefficient. \\
TC & minutes & $\begin{array}{l}\text { Duration of the triangular translation } \\
\text { hydrograph (time of concentration). }\end{array}$ \\
TP/TC & -- & $\begin{array}{l}\text { Ratio of time to peak to time of } \\
\text { concentration. }\end{array}$ \\
\hline
\end{tabular}

2. Uniform distribution of rainfall over the basin is a major assumption of the model. Any discharge events exhibiting an obviously unrepresentative response to rainfall (such as total rainfall less than total runoff) were excluded.

3. Events were excluded if field notes indicated that the culvert entrance may have been partially obstructed during the event, which could result in an amplified observed hydrograph.

4. Events were excluded if obvious datacollection problems occurred (such as snowmelt, plugged rainfall collector, or recorder malfunction).

Model parameters were systematically modified until a good fit of simulated to observed hydrographs was achieved.

About one-third of the events used for calibration were caused by frontal storms rather than by thunderstorms. The frontalstorm events generally occurred in early spring or mid-to-late fall and were generally characterized by better agreement between simulated and observed hydrographs than for thunderstorm-based events. The improved agreement probably is a result of the more uniform distribution (both spatial and temporal) of rainfall generally associated with frontal storms. Poorer agreement between simulated and observed hydrographs generally was associated with the thunderstorm events, although no bias was indicated for either the frontalstorm or thunderstorm events. The final values of parameters used in the calibrated models should allow for accurate year-round simulations of runoff caused by rain falling on unfrozen ground. 


\section{Hydrograph Synthesis}

Discharge hydrographs were synthesized for each site by use of the U.S. Geological Survey synthesis model (computer program E784, Carrigan and others, 1977). The model uses the calibrated parameter values from the rainfall-runoff model in combination with long-term rainfall and evaporation records to produce a long-term record of synthetic event hydrographs. Data from the closest long-term rainfall and evaporation stations were used to synthesize the long-term hydrograph data.

Rainfall data were selected from five longterm rainfall stations operated by the National Weather Service (fig. 1). U.S. Geological Survey computer program G159 was used to select the unit-rainfall data to be used in the long-term synthesis. This program scans the daily rainfall records and selects, for each year, up to five of the largest rainfall events that have 1- to 2-day rainfall totals greater than 1 inch. An average of three events per year were selected. The daily rainfall data and selected 5-minute rainfall data are used as input for the model.

Because of differences in rainfall characteristics between the study sites and the longterm rainfall sites, an adjustment of the daily and 5-minute rainfall data was considered necessary. Rainfall values at the long-term site were adjusted by multiplying them by the ratio of average annual rainfall at the study site to that of the long-term rainfall site. Average rainfall at the study sites was determined from an isohyetal map (Harstine, 1991) based on 50 years (1931-1980) of rainfall data from 205 National Weather Service stations. Average annual rainfall of the long-term rainfall sites for the 1931 to 1980 period was computed directly from the daily rainfall used for synthesis. The periods of record for each of the five long-term rainfall stations and number of rainfall events used for hydrograph synthesis are listed in table 5.
Table 5. National Weather Service rainfall stations used in synthesis of hydrograph data

\begin{tabular}{|c|c|c|c|}
\hline \multirow[b]{2}{*}{$\begin{array}{l}\text { Station } \\
\text { number }\end{array}$} & \multirow[b]{2}{*}{$\begin{array}{l}\text { Location and } \\
\text { Identifier } \\
\text { (fig. 1) }\end{array}$} & \multicolumn{2}{|r|}{ Record } \\
\hline & & $\begin{array}{c}\text { Numbe } \\
\text { of } \\
\text { years }\end{array}$ & $\begin{array}{c}\text { Number } \\
\text { of }\end{array}$ \\
\hline 390900084310000 & Cincinnati, Ohio (A) & 78 & $1897-1976247$ \\
\hline 391600081340001 & Parkersburg, W.Va. (B) & 77 & $1899-1975218$ \\
\hline 400000082530001 & Columbus, Ohio (C) & 75 & $1897-1977236$ \\
\hline 410000085130000 & Fort Wayne, Ind (D) & 66 & $1911-1977305$ \\
\hline 412400081510000 & Cleveland, Ohio (E) & 87 & $1890-1977171$ \\
\hline
\end{tabular}

Data were available from three dailyevaporation-data stations operated by the National Weather Service (fig. 1). Ten years of observed record at each site were used to generate an 85 -year synthetic record by use of computer program $\mathrm{H} 266$. The program averages the 10 daily-evaporation values for each day of the year for the 10-year period and uses those values for the 85-year synthetic record. Information on the periods of record for the daily evaporation sites is summarized in table 6.

Table 6. National Weather Service evaporation stations used in calibration of the rainfallrunoff models and in synthesis of hydrograph data

\begin{tabular}{|c|c|c|c|c|c|}
\hline \multirow[b]{2}{*}{$\begin{array}{l}\text { Station } \\
\text { number }\end{array}$} & \multirow[b]{2}{*}{$\begin{array}{l}\text { Location } \\
\text { and } \\
\text { Identifler } \\
\text { (fig. 1) }\end{array}$} & \multicolumn{2}{|c|}{$\begin{array}{c}\text { Observed } \\
\text { record }\end{array}$} & \multicolumn{2}{|c|}{$\begin{array}{l}\text { Synthetic } \\
\text { record }\end{array}$} \\
\hline & & $\begin{array}{l}\text { Num- } \\
\text { ber } \\
\text { of } \\
\text { years }\end{array}$ & Perlod & $\begin{array}{l}\text { Num } \\
\text { ber } \\
\text { of } \\
\text { years }\end{array}$ & $\begin{array}{l}\text { n- } \\
\text { rs Perlo }\end{array}$ \\
\hline 393800083130000 & $\begin{array}{l}\text { Deer Creek La } \\
\text { Oh }(\mathrm{X})\end{array}$ & 10 & $1975-1984$ & 85 & $1890-1974$ \\
\hline 402200081480000 & Coshocton, $\mathrm{OI}$ & (Y) 10 & $1975-1984$ & 85 & $1890-1974$ \\
\hline 411300083460000 & Hoytville, Oh & Z) 10 & $1975-1984$ & 85 & $1890-1974$ \\
\hline
\end{tabular}




\section{Volume-Duration-Frequency Analysis}

The modified version of the U.S. Geological Survey synthesis program E784 was used to analyze flood volumes of the 62 rural and urban study sites as a function of duration and frequency. For each station, the modified program scans the long-term synthetic hydrograph (discharge) data, and computes the largest runoff volume for each of six durations $(1,2,4,8$, 16 , and 32 hours) for each water year.

The volume selection and computation procedure for a single event is illustrated in figure 5. This procedure is performed on all the events for each year, and the annual maximums determined for each duration are used in the volume-frequency analysis. Usually, the maximum volumes for all six durations are computed from the same event. However, the short-duration volumes may be selected from a high-peak, short-duration hydrograph, whereas longer-duration volumes may be selected from a lower-peak, longer-duration hydrograph. About half of the storms producing annual maximum volumes occurred in the summer. The other half of the storms occurred primarily during spring and fall and were evenly divided between spring and fall. Only a few storms producing annual maximums occurred in the winter.

The logarithms of the annual peak volumes for each duration are then fit by a Pearson Type III frequency distribution. The frequency analyses were performed as recommended by the Interagency Advisory Committee on Water Data (1982). The skew coefficient used for each site was computed directly from the synthesized data. The regional skew map provided by the Committee was not used because it was developed from annual-peak-discharge data and may not represent skew coefficients of annual peak volumes.

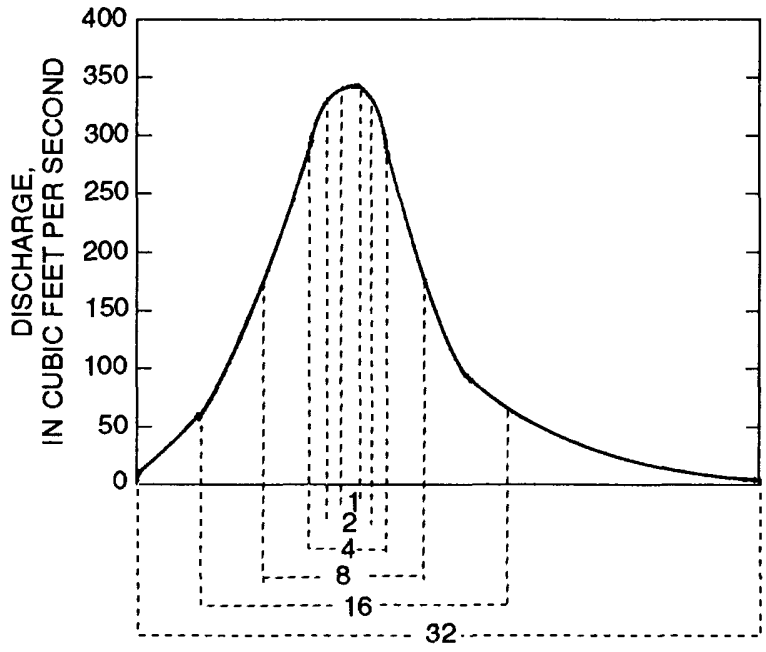

DURATION, IN HOURS

Figure 5.--Selection of runoff data for computation of volume for each of six durations $(1,2,4,8,16$, and 32 hours).

Previous investigators have shown that variance in synthetic annual flood data tends to be less than that in observed annual flood data (Lichty and Liscum, 1978; Thomas, 1982). This reduction in variance appears to be at least partially due to a smoothing effect of the rainfall-runoff model. The reduction in variance (and, consequently, in standard deviation) of annual flood peaks results in a flattening of the flood-frequency curve for synthetic data; thus, flood estimates for long recurrence intervals (for example, $\mathrm{Q}_{100}$ ) can be considerably lower than estimates based on observed data. At the same time, the flood estimates for short recurrence intervals (for example, $\mathrm{Q}_{2}$ ) can be relatively unaffected.

Several techniques have been applied to compensate for the bias caused by this loss of variance. Lichty and Liscum (1978) used a bias-adjustment factor, which is the average ratio of the observed to synthetic flood estimates for the 98 sites in their study for which synthetic and observed data were available. 
The bias-adjustment factors, ranging from 0.98 for the 2-year flood to 1.29 for the 100-year flood, were multiplied by the synthetic floodfrequency data to remove the bias and compute an estimated observed flood-frequency curve with increased discharges at the higher recurrence intervals. Inman (1988) used a technique described by Kirby (1975) in which the standard deviation of the synthetic annual flood data is divided by the magnitude of a coefficient of correlation between observed and simulated peak discharges determined in the final calibration run. A new frequency curve was then computed by use of the adjusted standard deviation and the original mean and skew coefficient. Adjusting the frequency curves in this manner increases discharges at the higher recurrence intervals.

In Ohio, it was not possible to compute bias-adjustment factors as Lichty and Liscum (1978) did because record lengths (5-8 years) for sites with synthetic data were too short to compute corresponding observed flood frequency curves for which a minimum of 10 years of record is needed (Interagency Advisory Committee on Water Data, 1982). Also, Kirby's method was not usable in Ohio because there appeared to be little relation between the coefficients of correlation between simulated and observed peak discharges and the standard deviations of simulated and observed peak discharges in the final calibration run.

For this study, a method was needed to compensate for reduction in variance of synthetic flood data. To accomplish this, an adjustment factor was computed as the ratio of the mean of the coefficients of variation (standard deviations divided by the means) of the logarithms of the annual-peak discharges collected at 97 rural sites having observed data to the mean of the corresponding coefficients of variation of the 32 rural study sites from this study with synthetic data.
The range in drainage area for the 32 rural sites with synthetic data is 0.13 to 6.45 square miles, and the average equivalent years of record ${ }^{3}$ for the 32 sites is 21 years for the 100 year flood estimate. The mean coefficient of variation of the logarithms of synthetic annual peak discharges for the 32 sites is 0.146 .

The 97 rural sites for which observed annual-peak data are available were selected from a data base of 275 rural, unregulated streams in Ohio and adjacent states. The 97 sites were chosen to have drainage areas between 0.13 and 6.45 square miles in order to make the synthetic and observed data comparable. The average length of systematic record for the 97 sites is 20.5 years. The mean coefficient of variation of the logarithms of observed annual peak discharges for the 97 sites is 0.173 .

The ratio of the mean coefficients of variation for the two data sets is $1.18(0.173 / 0.146)$. The standard deviations of the logarithms of the synthetic annual maximum volumes for each duration for the 62 study sites were multiplied by an adjustment factor of 1.18 . Adjusted volume-duration-frequency curves were then computed by use of the adjusted standard deviations and the original means and skew coefficients. The ratio of the coefficients of variation (1.18) of the two data sets was used as an adjustment factor instead of the ratio of the standard deviations (1.20) to minimize the effect of the mean (which is affected by drainage area) on the standard deviation. Comparable standard deviation ratios of 1.23 and 1.25 were computed for data reported by Thomas (1982) and Lichty and Liscum (1978), respectively, for which observed and synthetic

\footnotetext{
${ }^{3}$ The average equivalent years of record represents an estimate of the number of years of actual streamflow record required at a site to achieve an accuracy equivalent to the synthetic estimate and is computed by use of a method described by Hardison (1971).
} 
data were available. The study by Thomas (1982) was based on data from 50 small rural streams in Oklahoma. The study by Lichty and Liscum (1978) was based on data from 98 small rural streams in Missouri, Illinois, Tennessee, Mississippi, Alabama, and Georgia.

It was hypothesized that the standarddeviation adjustment factor applied to the annual-peak-discharge data could be applied to annual-peak-volume data as well, particularly for short durations (1-hour) that are highly correlated with the peak discharges.

The adjusted synthetic 100 -year volume data are listed in table 7 for all 62 rural and urban study sites. The relation between 100-year volumes and duration for six study sites is shown in figure 6 . The symbols on the graphs represent the volume-durationfrequency data computed for each site. The curved lines connecting the symbols are for illustration purposes only.

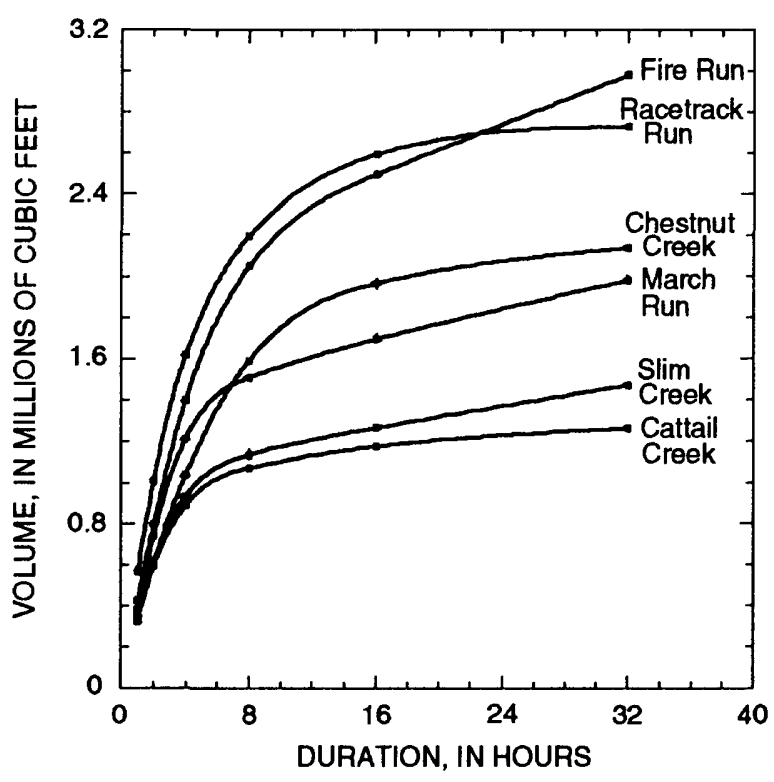

Figure 6.--One-hundred-year flood volumes as a function of duration for six study sites in Ohio.

\section{ESTIMATION OF FLOOD VOLUMES AT RURAL UNGAGED SITES}

It is neither feasible nor necessary to collect flood-volume data at all sites where such information may be required for the design of hydraulic structures. Because of the relations among streamflow characteristics and basin characteristics, it is possible to transfer information from gaged sites to ungaged sites (Thomas and Benson, 1970). Methods of transfer range from simple interpolation to complex computer-modeling techniques. Multiple regression, a method commonly used, which has been demonstrated to provide accurate, unbiased, and reproducible results (Newton and Herrin, 1982), was used in this study. The method is also relatively easy to apply.

\section{Development of Equations for Estimating Flood Volumes in Ohio}

Multiple regression is a technique that provides a mathematical equation of the relation between one response variable and two or more explanatory variables. The technique also provides a measure of the accuracy of the equation and a measure of the statistical significance of each explanatory variable in the equation. In the analysis, several combinations of explanatory variables are tested, and the combination that best fits the observed data is selected, provided that the inclusion of each explanatory variable is hydrologically valid and statistically significant.

The volume-duration-frequency data from the 62 rural and urban study sites were used in the following analyses. The reasons for combining the rural and urban data into a single data set for the volume analyses were previously discussed on page 4 . 
Table 7. One-hundred-year volumes $\left(\mathrm{dV}_{100}\right)$ for 62 study sites in Ohio

\begin{tabular}{|c|c|c|c|c|c|c|}
\hline \multirow[b]{2}{*}{ Station name } & \multicolumn{6}{|c|}{$\begin{array}{c}\text { Volume, in millions of cubic feet for indicated } \\
\text { duration, in hours }\end{array}$} \\
\hline & 1.0 & 2.0 & 4.0 & 8.0 & 16.0 & 32.0 \\
\hline (1) & 0.301 & 0.402 & 0.517 & 0.604 & 0.646 & 0.761 \\
\hline Anderson Ditch & .256 & .302 & .356 & .405 & .468 & .588 \\
\hline 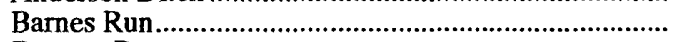 & 1.18 & 2.30 & 4.19 & 6.64 & 8.86 & 9.88 \\
\hline 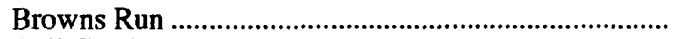 & 1.60 & 3.13 & 5.90 & 10.3 & 15.3 & 20.3 \\
\hline 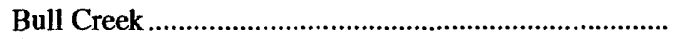 & 4.91 & 9.27 & 15.5 & 22.0 & 25.3 & 29.6 \\
\hline 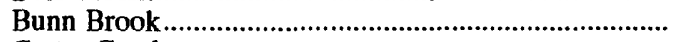 & 1.03 & 1.55 & 2.02 & 2.16 & 2.35 & 2.64 \\
\hline 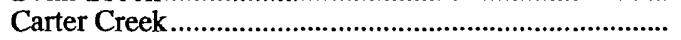 & .953 & 1.87 & 3.59 & 6.44 & 10.1 & 12.8 \\
\hline 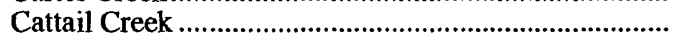 & .384 & .598 & .939 & 1.06 & 1.18 & 1.26 \\
\hline 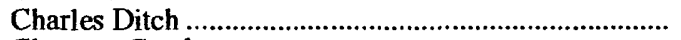 & 1.91 & 2.53 & 3.12 & 3.24 & 3.67 & 4.34 \\
\hline Chestnut Creek & .324 & .603 & 1.04 & 1.59 & 1.97 & 2.14 \\
\hline Claypit Creek & 2.64 & 5.11 & 9.33 & 15.3 & 20.9 & 25.0 \\
\hline Coalton Ditch & 1.44 & 2.27 & 3.06 & 3.42 & 3.63 & 3.89 \\
\hline 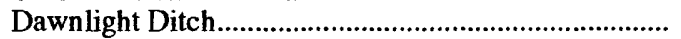 & .498 & .652 & .842 & .933 & 1.04 & 1.20 \\
\hline 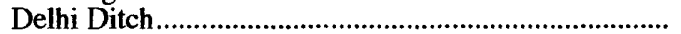 & .522 & .634 & .828 & 1.05 & 1.21 & 1.50 \\
\hline 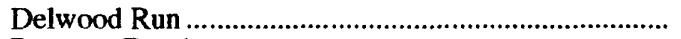 & .611 & 1.14 & 2.02 & 3.17 & 4.03 & 4.86 \\
\hline 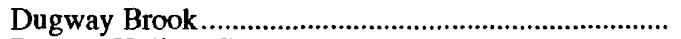 & 5.99 & 7.54 & 8.42 & 9.05 & 10.3 & 11.6 \\
\hline 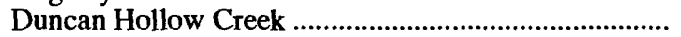 & .927 & 1.74 & 2.94 & 4.28 & 5.02 & 6.82 \\
\hline 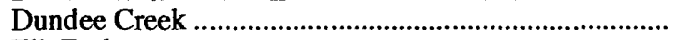 & 1.36 & 2.29 & 3.55 & 5.02 & 5.67 & 6.10 \\
\hline Elk Fork & 11.6 & 21.3 & 36.7 & 53.7 & 61.3 & 84.8 \\
\hline Elk Run & .953 & 1.79 & 3.00 & 4.16 & 4.68 & 4.99 \\
\hline 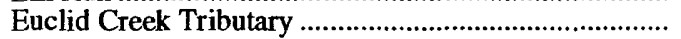 & 4.53 & 6.34 & 7.92 & 8.47 & 9.44 & 11.3 \\
\hline 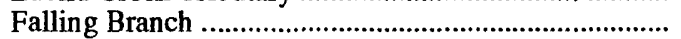 & .559 & 1.01 & 1.74 & 2.49 & 3.00 & 3.50 \\
\hline 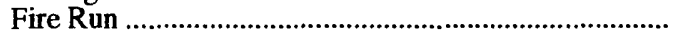 & .427 & .797 & 1.40 & 2.05 & 2.50 & 2.99 \\
\hline Fishinger Creek & 1.82 & 2.34 & 2.94 & 3.30 & 3.64 & 4.16 \\
\hline 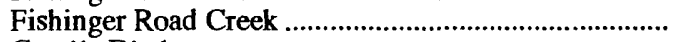 & 1.14 & 1.24 & 1.47 & 1.61 & 1.81 & 2.15 \\
\hline 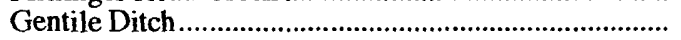 & .357 & .444 & .538 & .598 & .654 & .874 \\
\hline Glen Park Creek & 2.91 & 4.60 & 6.33 & 6.99 & 7.38 & 7.66 \\
\hline 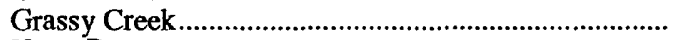 & 1.67 & 3.15 & 5.60 & 8.65 & 11.6 & 12.5 \\
\hline Harte Run & .680 & 1.30 & 2.35 & 3.77 & 5.35 & 6.27 \\
\hline 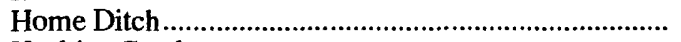 & .746 & 1.11 & 1.47 & 1.95 & 2.08 & 2.29 \\
\hline 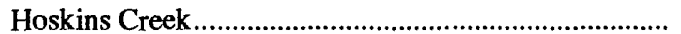 & 2.21 & 4.36 & 8.52 & 16.2 & 29.5 & 48.1 \\
\hline Ketchum Ditch & .693 & 1.31 & 2.32 & 3.73 & 4.70 & 4.87 \\
\hline King Run & .730 & 1.34 & 2.23 & 3.14 & 3.79 & 3.96 \\
\hline 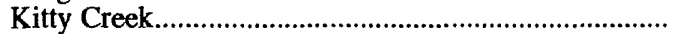 & 2.06 & 4.04 & 7.46 & 11.7 & 14.8 & 17.3 \\
\hline Mall Run & .871 & 1.03 & 1.22 & 1.34 & 1.41 & 1.67 \\
\hline 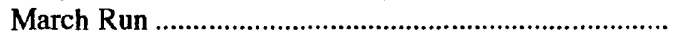 & .394 & .743 & 1.21 & 1.51 & 1.70 & 1.98 \\
\hline Norman Ditch & 1.44 & 2.04 & 2.66 & 2.88 & 3.26 & 3.96 \\
\hline 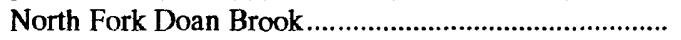 & 4.64 & 5.55 & 6.80 & 7.38 & 8.29 & 9.27 \\
\hline Orchard Run. & 1.34 & 1.77 & 2.23 & 2.32 & 2.63 & 2.73 \\
\hline 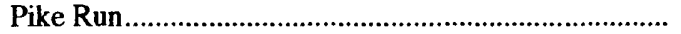 & 2.14 & 3.06 & 3.71 & 4.62 & 4.96 & 5.21 \\
\hline Racetrack Run & .567 & 1.01 & 1.62 & 2.20 & 2.60 & 2.70 \\
\hline 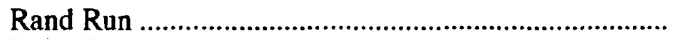 & .575 & 1.02 & 1.61 & 2.13 & 2.33 & 2.46 \\
\hline 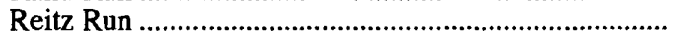 & .555 & 1.10 & 2.13 & 3.90 & 6.42 & 8.73 \\
\hline Rush Run & .838 & 1.63 & 2.89 & 4.28 & 5.29 & 6.23 \\
\hline 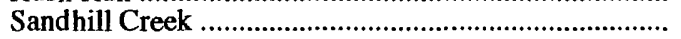 & 2.22 & 4.27 & 7.63 & 11.6 & 14.7 & 16.8 \\
\hline 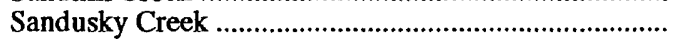 & 1.26 & 2.26 & 3.98 & 5.44 & 6.06 & 6.42 \\
\hline Second Creek & 2.40 & 4.08 & 5.97 & 7.98 & 9.08 & 9.32 \\
\hline 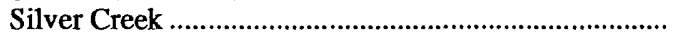 & 1.37 & 2.44 & 3.69 & 5.59 & 6.24 & 6.32 \\
\hline 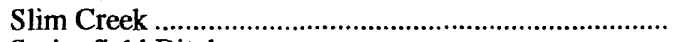 & .349 & .617 & .937 & 1.14 & 1.27 & 1.47 \\
\hline 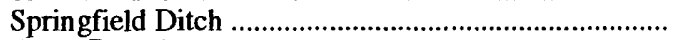 & 1.26 & 1.50 & 1.85 & 1.96 & 2.05 & 2.63 \\
\hline 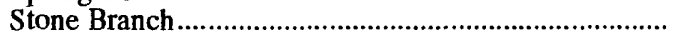 & 2.39 & 3.85 & 6.23 & 8.27 & 10.0 & 13.7 \\
\hline 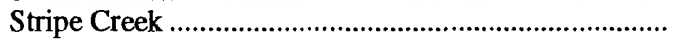 & .882 & 1.75 & 3.40 & 6.24 & 10.2 & 13.5 \\
\hline 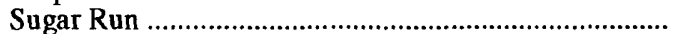 & 3.62 & 6.41 & 10.0 & 13.3 & 16.2 & 22.9 \\
\hline Sweet Henri Ditch & 1.38 & 1.87 & 2.33 & 2.40 & 2.73 & 3.19 \\
\hline Tifft Ditch & 1.22 & 1.87 & 2.50 & 3.31 & 3.48 & 3.59 \\
\hline 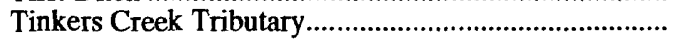 & .478 & .677 & .860 & .934 & 1.15 & 1.39 \\
\hline 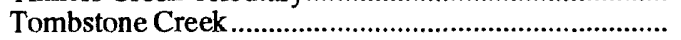 & 3.93 & 7.61 & 13.9 & 22.8 & 31.0 & 37.9 \\
\hline 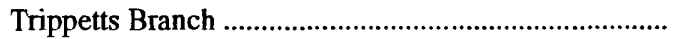 & .956 & 1.63 & 2.46 & 2.88 & 3.39 & 4.63 \\
\hline 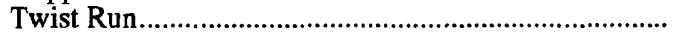 & 1.32 & 2.33 & 3.72 & 5.76 & 7.81 & 10.6 \\
\hline Whipps Ditch & 7.85 & 12.3 & 17.8 & 22.9 & 25.7 & 31.5 \\
\hline 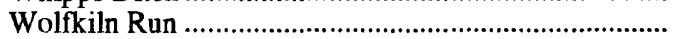 & 1.05 & 1.97 & 3.55 & 5.76 & 7.68 & 8.58 \\
\hline 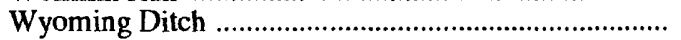 & .160 & .206 & .251 & .277 & .302 & .397 \\
\hline
\end{tabular}




\section{Flood Volumes as a Function of Basin Characteristics}

Flood-volume data for all combinations of the six durations $(1,2,4,8,16$, and 32 hours) and six recurrence intervals $(2,5,10,25,50$, and 100 years) were analyzed as a function of basin characteristics. The 36 volume-durationfrequency data sets can be identified by abbreviations in the form $\mathrm{dV}_{\mathrm{T}}$, in which $\mathrm{V}$ is total volume, in millions of cubic feet; $d$ is duration, in hours; and $\mathrm{T}$ is recurrence interval, in years. For example, $4 \mathrm{~V}_{50}$ identifies the maximum 4-hour volume with a 50-year recurrence interval. The 36 volume-duration-frequency data sets (response variables) initially were related to a variety of basin characteristics (explanatory variables) in the multiple-regression analysis.

The basin characteristics ${ }^{4}$ tested were:

$\begin{array}{rrl}\text { A } & -- & \text { drainage area } \\ \text { L } & -- & \text { main-channel length } \\ \text { SL } & -- & \text { main-channel slope } \\ \mathrm{L} / \mathrm{VSL} & -- & \begin{array}{l}\text { main-channel length divided } \\ \text { by the square root of the main- } \\ \end{array} \\ & & \text { channel slope } \\ \mathrm{F} & -- & \text { forested area } \\ \mathrm{P} & -- & \text { average annual precipitation } \\ \mathrm{ST} & -- & \text { storage area } \\ \mathrm{BDF} & -- & \text { basin-development factor } \\ 2 \mathrm{RF}_{25} & -- & \text { 2-hour, 25-year rainfall } \\ 2 \mathrm{RF}_{100} & -- & \text { 2-hour, 100-year rainfall } \\ 6 \mathrm{RF}_{25} & -- & \text { 6-hour, 25-year rainfall } \\ 6 \mathrm{RF}_{100} & -- & \text { 6-hour, 100-year rainfall } \\ 12 \mathrm{RF}_{25} & -- & \text { 12-hour, 25-year rainfall } \\ 12 \mathrm{RF}_{100} & -- & \text { 12-hour, 100-year rainfall. }\end{array}$

${ }^{4}$ See glossary for definitions of terms
These basin characteristics were chosen for consideration in this analysis because of their significance in previous flood-frequency studies in Ohio (Webber and Bartlett, 1977; Sherwood, 1986; Koltun and Roberts, 1990) and elsewhere. Basin-development factor (BDF) was included in the multiple-regression analyses to account for the effects of urbanization on volumes of short duration at the urban sites.

The multiple-regression analysis was performed by use of the Statistical Analysis System $^{5}$ (SAS Institute, 1982). A combination of step-forward and step-backward procedures was used to initially screen the basin characteristics for inclusion in the 36 regression equations. A, P, SL, F, and BDF were found to be statistically significant in the multiple-regression analyses.

The values of the five explanatory variables (A, P, SL, F, and BDF) that were significant in the regression analysis are listed in table 8. The statistical distributions of $\mathrm{A}, \mathrm{P}$, $\mathrm{SL}$, and $\mathrm{F}$ are illustrated in the box plots in figure 7. Four transformations of variables were made during the regression analyses to improve the linearity of the relations between the response and explanatory variables and to reduce the standard errors:

1. A constant of 30 inches was subtracted from all values of $P$. The minimum value of $P$ for the State of Ohio is about 31 inches.

2. A constant of 10 percent was added to all values of $F$. Values of $5,10,15$, and 20 percent were tested, and 10 percent produced the best results.

${ }^{5}$ Use of trade names in this report is for identification purposes only and does not constitute endorsement by the U.S. Geological Survey. 
Table 8. Values of the significant explanatory variables in the volume-duration-frequency equations for 62 study sites in Ohio

[A, drainage area (in square miles); $\mathrm{P}$, average annual precipitation (in inches); SL, main-channel slope (in feet per mile); $\mathrm{F}$, forested area (in percent); $\mathrm{BDF}$, basin-development factor (scale of 0 to 12]

\begin{tabular}{|c|c|c|c|c|c|}
\hline Station name & $\mathbf{A}$ & $\mathbf{P}$ & $\mathbf{S L}$ & $\mathbf{F}$ & BDF \\
\hline Amberly Ditch & 0.14 & 39.8 & 287 & 21.2 & 9 \\
\hline Anderson Ditch & .049 & 40.1 & 333 & 26.5 & 8 \\
\hline 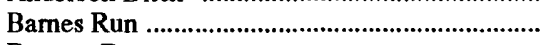 & 1.02 & 40.1 & 105 & 22.3 & 0 \\
\hline Browns Run & 2.00 & 35.4 & 13.4 & 8.1 & 0 \\
\hline 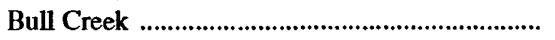 & 3.13 & 39.0 & 60.4 & 70.0 & 0 \\
\hline 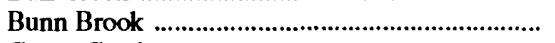 & .51 & 35.6 & 58.3 & 0.0 & 8 \\
\hline Carter Creek & 1.16 & 34.7 & 13.8 & 12.6 & 0 \\
\hline 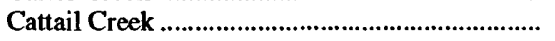 & .13 & 36.9 & 179 & 35.7 & 0 \\
\hline 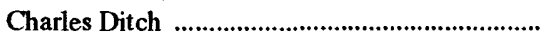 & .50 & 35.3 & 31.5 & 7.8 & 11 \\
\hline Chestnut Creek & .22 & 41.3 & 164 & 53.4 & 0 \\
\hline Claypit Creek & 2.25 & 39.1 & 73.6 & 74.1 & 0 \\
\hline Coalton Ditch & .50 & 41.2 & 110 & 47.4 & 0 \\
\hline 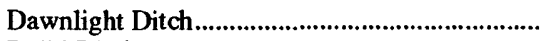 & .20 & 36.8 & 65.0 & 0.0 & 8 \\
\hline 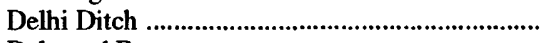 & .16 & 40.1 & 127 & 0.0 & 10 \\
\hline 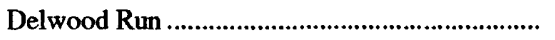 & .45 & 35.0 & 45.1 & 5.1 & 0 \\
\hline 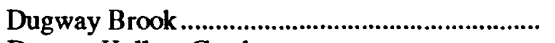 & 1.42 & 39.0 & 70.9 & 0.0 & 12 \\
\hline Duncan Hollow Creek ...................................... & .51 & 41.6 & 276 & 97.4 & 0 \\
\hline Dundee Creek & .74 & 37.5 & 116 & 15.8 & 0 \\
\hline Elk Fork & 6.45 & 42.5 & 38.2 & 8.1 & 0 \\
\hline Elk Run & .48 & 40.7 & 141 & 50.0 & 0 \\
\hline Euclid Creek Tributary & 1.67 & 39.4 & 44.0 & 0.0 & 11 \\
\hline Falling Branch & .33 & 38.3 & 136 & 47.0 & 0 \\
\hline Fire Run & .24 & 40.9 & 124 & 67.9 & 0 \\
\hline Fishinger Creek & .66 & 37.2 & 61.5 & 0.0 & 9 \\
\hline Fishinger Road Creek ........................................... & .45 & 37.1 & 73.7 & 0.0 & 11 \\
\hline Gentile Ditch & .064 & 39.2 & 44.4 & 0.0 & 12 \\
\hline 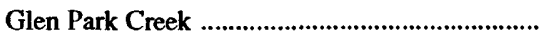 & 1.21 & 33.8 & 48.6 & 5.2 & 4 \\
\hline Grassy Creek & 1.81 & 31.7 & 8.6 & 1.4 & 6 \\
\hline Harte Run & .86 & 37.0 & 20.2 & 5.2 & 0 \\
\hline Home Ditch & .24 & 39.9 & 68.3 & 29.4 & 3 \\
\hline 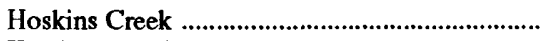 & 5.42 & 42.5 & 21.8 & 39.0 & 0 \\
\hline Ketchum Ditch & .84 & 31.5 & 13.0 & 1.4 & 10 \\
\hline King Run & .53 & 35.4 & 65.0 & 10.0 & 0 \\
\hline Kitty Creek & 1.75 & 37.2 & 39.2 & 4.9 & 0 \\
\hline Mall Run & .16 & 38.5 & 78.5 & 4.4 & 12 \\
\hline March Run & .18 & 36.8 & 118 & 34.0 & 0 \\
\hline Norman Ditch & .60 & 37.2 & 46.2 & 0.0 & 10 \\
\hline North Fork Doan Brook ........................................... & 1.18 & 39.1 & 86.3 & 0.0 & 10 \\
\hline 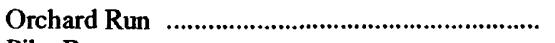 & .43 & 36.9 & 116 & 2.3 & 11 \\
\hline Pike Run & 1.18 & 35.8 & 24.8 & 0.8 & 7 \\
\hline Racetrack Run & .34 & 34.0 & 30.8 & 7.4 & 0 \\
\hline Rand Run & .33 & 38.3 & 141 & 9.1 & 4 \\
\hline 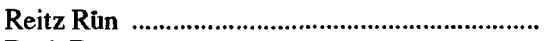 & .98 & 31.9 & 13.8 & 1.3 & 0 \\
\hline 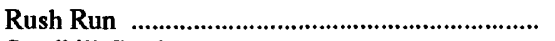 & .72 & 36.6 & 8.0 & 1.4 & 2 \\
\hline 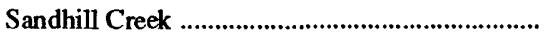 & 1.76 & 35.6 & 16.1 & 8.0 & $\mathbf{0}$ \\
\hline 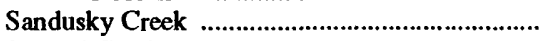 & .73 & 41.8 & 124 & 84.9 & 0 \\
\hline Second Creek & 1.04 & 38.8 & 115 & 30.8 & 0 \\
\hline Silver Creek & 4.09 & 31.6 & 14.8 & 8.6 & 6 \\
\hline Slim Creek & .13 & 38.4 & 105 & 13.5 & 0 \\
\hline 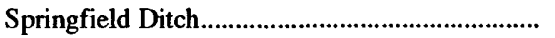 & .26 & 39.8 & 117 & 7.0 & 9 \\
\hline 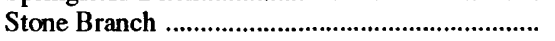 & .84 & 42.1 & 76.3 & 6.0 & 0 \\
\hline 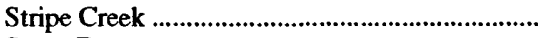 & 1.26 & 36.0 & 7.6 & 5.0 & 0 \\
\hline Sugar Run & 1.37 & 42.8 & 63.2 & 14.8 & 0 \\
\hline 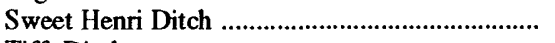 & .36 & 36.7 & 72.2 & 21.1 & 5 \\
\hline 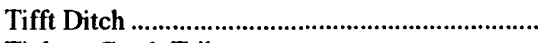 & .85 & 31.7 & 19.4 & 8.2 & 8 \\
\hline Tinkers Creek Tributary....................................... & .12 & 40.5 & 94.9 & 0.0 & 3 \\
\hline Tombstone Creek & 4.03 & 36.9 & 21.1 & 10.9 & 0 \\
\hline Trippetts Branch & .33 & 38.2 & 145 & 37.9 & 0 \\
\hline 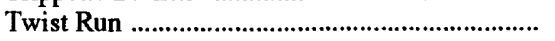 & .65 & 40.0 & 63.3 & 8.5 & 0 \\
\hline 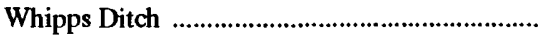 & 2.64 & 40.3 & 58.9 & .8 & 9 \\
\hline Wolfkiln Run & .87 & 40.3 & 108 & 77.6 & 0 \\
\hline 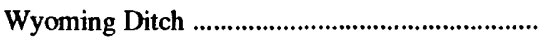 & .026 & 39.7 & 462 & 5.8 & 11 \\
\hline
\end{tabular}



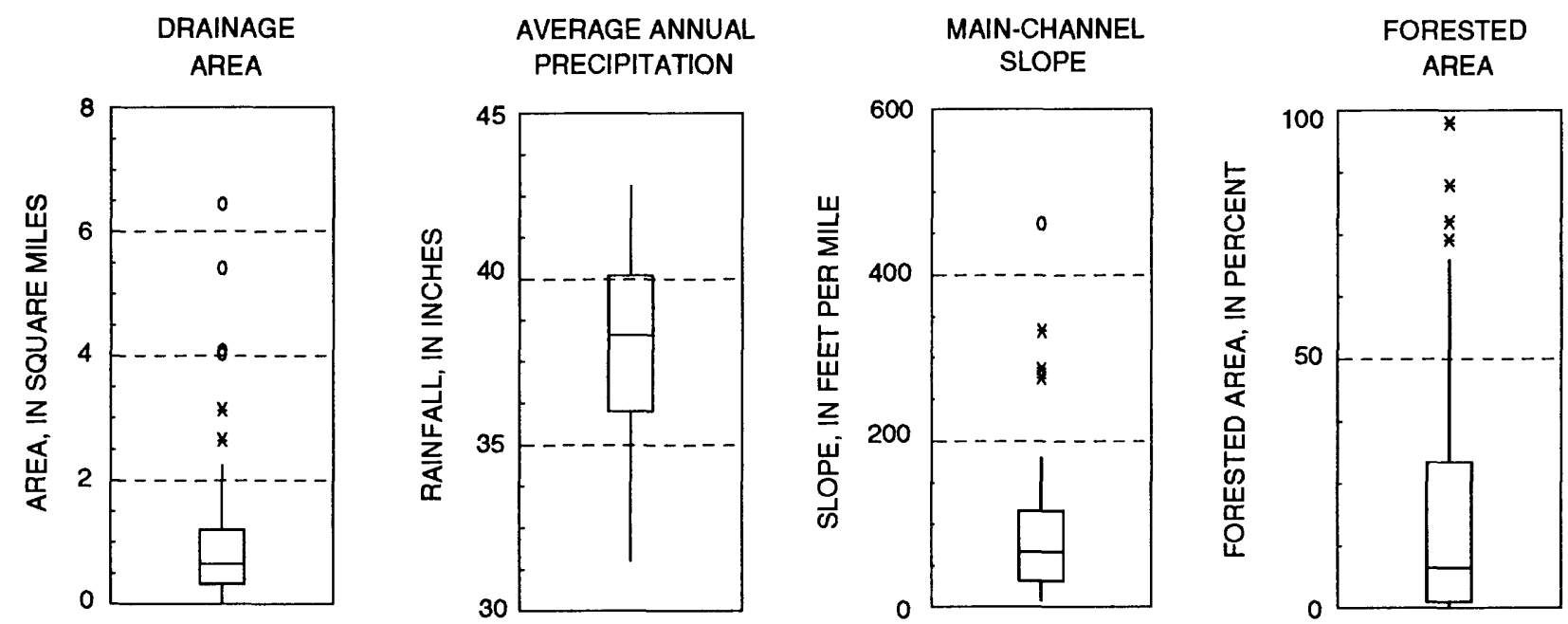

\section{EXPLANATION}

0

DETACHED VALUE ${ }^{1}$

* outside VALUE 2

${ }^{1} A$ detached value is defined as a value that is greater than 3 times the interquartile range (beyond the box).

\begin{tabular}{l} 
UPPER WHISKER \\
MEDIAN \\
25TH PERCENTILE \\
\hline \\
LOWER WHISKER
\end{tabular}

${ }^{2}$ An outside value is defined as greater than 1.5 and less than or equal to 3 interquartile ranges from the box.

${ }^{3}$ Upper whisker is defined as the largest data point less than or equal to the upper quartile plus 1.5 times the interquartile range.

${ }^{4}$ Lower whisker is defined as the smaller data point greater than or equal to the lower quartile minus 1.5 times the interquartile range.

LOWER WHISKER ${ }^{4}$

Figure 7.--Box plots showing the ranges, 25 th and 75 th percentiles, and median values of the four explanatory vanables from 62 study sites in Ohio. 
3. BDF was subtracted from 13. In a nationwide urban study, Sauer and others (1983) found that equation accuracy was improved if BDF was used on a reverse scale (13-BDF). In this study, both BDF and 13BDF were tested, and 13-BDF yielded the best results.

4. The final values of all response $\left(\mathrm{dV}_{\mathrm{T}}\right)$ and explanatory (A, P-30, SL, F+10, 13-BDF) variables were transformed by taking base10 logarithms. Past experience in hydrologic studies has shown that the linearity of many relations between streamflow characteristics and basin characteristics is improved if the logarithms of each are used (Thomas and Benson, 1970).

While BDF was found to be statistically significant in the regression analyses of shortduration (1-4 hours) volumes, it does not appear in the final equations because it has been included in the regression constant. $\mathrm{BDF}$ is a measure of basin development that takes into account channel improvements (in terms of the ability of the channel to transport water), impervious channel linings, storm sewers, and curb-and-gutter streets. BDF is measured on a scale from 0 (little or no development) to 12 (fully developed). Rather than explicitly include BDF in equations developed as part of a rural volume study, a value of zero was given to BDF, (13-0) was raised to the computed power, and multiplied by the regression constant as shown in the following example for the 1-hour, 2-hour equation:

\section{Urban}

$1 \mathrm{~V}_{2}=(0.42)(\mathrm{A})^{0.77}(\mathrm{P}-30)^{0.43}(13-\mathrm{BDF})^{-0.41}$

$$
\begin{aligned}
& \text { Rural } \\
& 1 \mathrm{~V}_{2}=(0.42)(\mathrm{A})^{0.77}(\mathrm{P}-30)^{0.43}(13-0)^{-0.41} \\
& 1 \mathrm{~V}_{2}=(0.42)(\mathrm{A})^{0.77}(\mathrm{P}-30)^{0.43}(0.349) \\
& 1 \mathrm{~V}_{2}=(0.42)(0.349)(\mathrm{A})^{.77}(\mathrm{P}-30)^{0.43} \\
& 1 \mathrm{~V}_{2}=(0.15)(\mathrm{A})^{0.77}(\mathrm{P}-30)^{0.43}
\end{aligned}
$$

The final equations for rural areas, with BDF set equal to zero and included in the regression constant, are shown in table 9. The same equations as shown in table 9 , but with BDF present in the equations (not included in the regression constant), are presented in an urban flood report by Sherwood (1993) and may be used to estimate volume-durationfrequency relations of small urban streams in Ohio.

Six alternative equations, which include SL and F, for estimating flood volumes of 1- and 2-hour durations and 25-, 50-, and 100-year recurrence intervals for rural streams in Ohio, are listed in table 10. BDF was also statistically significant in the multiple-regression analyses but does not appear in the equations listed in table 10 because BDF has been set to zero and included in the regression constant as illustrated on this page for one of the equations from table 9 . The equations listed in table 10 will provide some improvement in accuracy over those listed in table 9 (which do not include SL and F). The table 10 equations may be particularly useful for ungaged sites where the values for SL or F are extreme (high or low). All equations listed in tables 9 and 10 were derived from the same data set of 62 rural and urban sites.

The equations listed in tables 9 and 10 may be used to estimate maximum flood volumes of specific duration and recurrence interval for small rural streams in Ohio. The accuracy and limitations associated with the equations are discussed in subsequent parts of this report. Also listed in tables 9 and 10 are the average standard error of regression (SER) and average standard error of prediction (SEP) for each equation.

The average standard error of regression, in the context of this analysis, is a measure of an average error between synthetic volumes and regression-estimated volumes of the 62 gaged sites and indicates how well the equations estimate flood volumes of the 62 gaged sites used in the regression analysis. The 
average standard error of prediction, however, is an approximation of the accuracy of the equations for estimating flood volumes at ungaged sites not included in the regression analysis. It is computed by leaving out one site, developing an equation based on the other 61 sites, and computing the residual for the site left out. The process is repeated for each site, and the 62 residuals are squared and summed. The sum of the squared residuals, called the PRESS statistic (Montgomery and Peck, 1982), may be computed by various statistical computer programs, including the Statistical Analysis System (SAS Institute, 1982). The standard error of prediction is then computed by taking the square root of the PRESS statistic multiplied by $\gamma$, where $\gamma$ is defined as (Edward J. Gilroy, U.S. Geological Survey, Reston, Virginia, written commun., 1988):

$$
\gamma=\left(\frac{n-1}{n}\right)\left(\frac{n-p-3}{n-p-2}\right)\left(\frac{n+1}{n}\right)\left(\frac{n-2}{n-3}\right)\left(\frac{1}{n}\right)
$$

where $n$ is the number of observations, and $p$ is the number of degrees of freedom.

The average standard errors of regression and prediction listed in tables 9 and 10 were computed for the respective equations with all significant variables including BDF.

Drainage area (A), basin-development factor $(\mathrm{BDF})$, percent forest $(\mathrm{F})$, average annual precipitation $(\mathrm{P})$, and main-channel slope (SL) had median significance levels equal to or less than 1 percent for at least some of the volumeduration-frequency equations as shown in the following matrix.

\section{A $\quad$ BDF $\quad F \quad$ P $\quad$ SL}

\begin{tabular}{rlllll}
\hline $1 \mathrm{hr}$ & $X$ & $X$ & $X$ & $X$ & $X$ \\
$2 \mathrm{hr}$ & $X$ & $X$ & $X$ & $X$ & $X$ \\
$4 \mathrm{hr}$ & $\mathrm{X}$ & $\mathrm{X}$ & & $X$ & \\
$8 \mathrm{hr}$ & $\mathrm{X}$ & & & $X$ & \\
$16 \mathrm{hr}$ & $\mathrm{X}$ & & & $X$ & \\
$32 \mathrm{hr}$ & $\mathrm{X}$ & & & $X$ &
\end{tabular}

The inclusion of A, P, SL, and F in the equations, as well as the signs and magnitudes of their regression exponents, appear to be appropriate from a hydrologic standpoint. SL and $F$ are basin characteristics that affect the shape of a hydrograph more than they affect total volume and therefore were not statistically significant in the long-duration (4-, 8-, 16-, and 32-hour) equations that estimate a larger part of the total volume of the hydrograph. SL and F also appear to have a greater effect on large floods than small floods, as indicated by SL and F not being statistically significant in the 2-, 5-, and 10-year equations.

\section{Tests for Intercorrelation and Bias}

All significant variables were checked for intercorrelation. A high degree of intercorrelation between explanatory variables may affect the magnitude and sign of their regression exponents as well as reducing their statistical significance. Values of Pearson correlation coefficients may range from +1.0 to -1.0 ; computed values close to +1.0 or -1.0 indicate a high degree of intercorrelation. The following matrix shows the Pearson correlation coefficients of the base- 10 logarithms of the four explanatory variables in the volume-durationfrequency equations:
A
P-30
SL $\quad \mathrm{F}+10$

$\begin{array}{lrrrr}\text { A } & 1.00 & -0.22 & -0.61 & -0.03 \\ \text { P-30 } & & 1.00 & +0.64 & +0.37 \\ \text { SL } & & & 1.00 & +0.44 \\ \text { F+10 } & & & & 1.00\end{array}$

The most highly correlated variables, SL and P-30, have a correlation coefficient of +0.64 . The Pearson correlation coefficient and other statistical tests for multi-collinearity 
Table 9. Equations for estimating volume-duraton-frequency $\left(\mathrm{dV}_{\mathrm{T}}\right)$ relations of small rural streams in Ohio

[SER, average standard error of regression (in percent); SEP, average standard error of prediction (in percent); $\mathrm{dV}_{\mathrm{T}}$, flood volume of $d$ hours duration and $T$ years recurrence interval (in millions of cubic feet); A, drainage area (in square miles); $\mathrm{P}$, average annual precipitation (in inches)]

\begin{tabular}{|c|c|c|c|}
\hline $\begin{array}{l}\text { Equation } \\
\text { number }\end{array}$ & Equation & \multicolumn{2}{|c|}{ (in percent) } \\
\hline \multicolumn{4}{|c|}{2 - year equations } \\
\hline (1) & $1 V_{2}=0.15(A)^{0.77}(P-30)^{0.43}$ & \pm 38.1 & \pm 39.4 \\
\hline (2) & $2 V_{2}=0.30(A)^{0.81}(P-30)^{0.38}$ & \pm 37.0 & \pm 38.4 \\
\hline (3) & $=0.53(A)^{0.85}(P-30)^{0.33}$ & \pm 36.3 & \pm 37.9 \\
\hline (4) & $=0.79(A)^{0.89}(P-30)^{0.32}$ & \pm 37.3 & \pm 39.0 \\
\hline (5) & $16 V_{2}=0.96(A)^{0.93}(P-30)^{0.32}$ & \pm 39.6 & \pm 41.4 \\
\hline (6) & $=1.11(A)^{0.95}(P-30)^{0.32}$ & \pm 41.7 & \pm 43.7 \\
\hline \multicolumn{4}{|c|}{5 - year equations } \\
\hline (7) & $1 V_{5}=0.23(A)^{0.76}(P-30)^{0.49}$ & \pm 35.1 & \pm 36.4 \\
\hline (8) & $2 V_{5}=0.46(A)^{0.80}(P-30)^{0.42}$ & \pm 32.9 & \pm 34.2 \\
\hline (9) & $4 V_{5}=0.83(A)^{0.84}(P-30)^{0.39}$ & \pm 31.1 & \pm 32.6 \\
\hline (10) & $8 V_{5}=1.19(A)^{0.90}(P-30)^{0.37}$ & \pm 31.5 & \pm 33.2 \\
\hline (11) & $16 V_{5}=1.45(A)^{0.94}(P-30)^{0.37}$ & \pm 34.2 & \pm 36.0 \\
\hline (12) & $32 V_{5}=1.63(A)^{0.95}(P-30)^{0.39}$ & \pm 36.8 & \pm 38.7 \\
\hline \multicolumn{4}{|c|}{10 - year equations } \\
\hline (13) & $1 V_{10}=0.29(A)^{0.76}(P-30)^{0.51}$ & \pm 34.8 & \pm 36.2 \\
\hline (14) & $2 V_{10}=0.59(A)^{0.80}(P-30)^{0.45}$ & \pm 32.0 & \pm 33.4 \\
\hline (15) & $4 V_{10}=1.05(A)^{0.84}(P-30)^{0.40}$ & \pm 29.6 & \pm 31.2 \\
\hline (16) & $8 V_{10}=1.52(A)^{0.90}(P-30)^{0.38}$ & \pm 29.4 & \pm 31.0 \\
\hline (17) & $16 V_{10}=1.85(A)^{0.94}(P-30)^{0.38}$ & \pm 32.1 & \pm 33.9 \\
\hline (18) & $32 V_{10}=2.05(A)^{0.96}(P-30)^{0.41}$ & \pm 34.8 & \pm 36.7 \\
\hline
\end{tabular}


Table 9. Equations for estimating volume-duraton-frequency $\left(\mathrm{dV}_{\mathrm{T}}\right)$ relations of small rural streams in Ohio--Continued

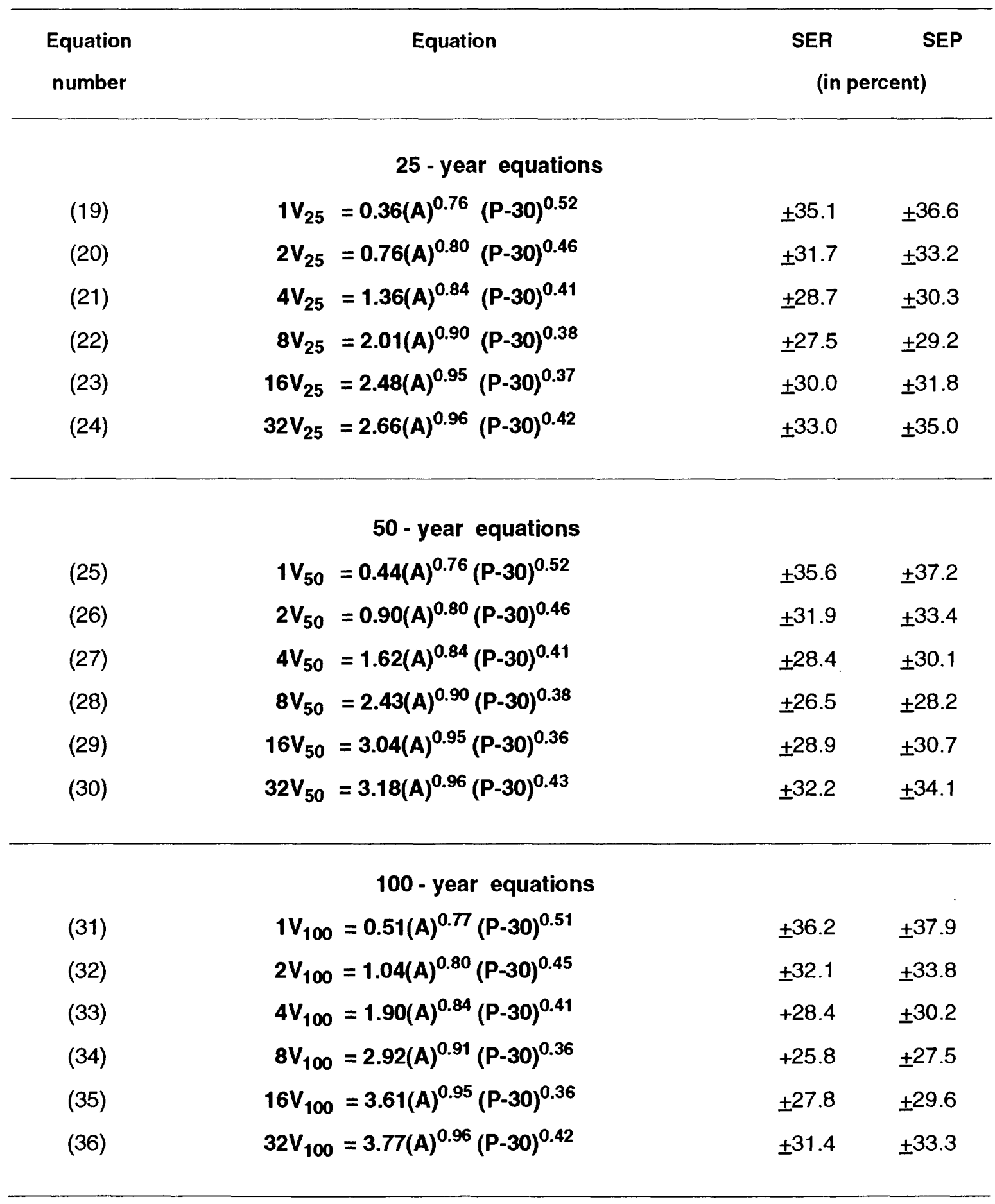


Table 10. Alternate equations for estimating flood volumes of 1- and 2-hour durations and 25-, 50-, and 100-year recurrence intervals for small rural streams in Ohio

[SER, average standard error of regression (in percent); SEP, average standard error of prediction (in percent); $\mathrm{dV}_{\mathrm{T}}$, flood volume of $\mathrm{d}$ hours duration and $\mathrm{T}$ years recurrence interval (in millions of cubic feet); $\mathrm{A}$, drainage area (in square miles); $\mathrm{P}$, average annual precipitation (in inches); $\mathrm{SL}$, main-channel slope (in feet per mile); $\mathrm{F}$, forested area (in percent)]

\begin{tabular}{ccc}
\hline $\begin{array}{c}\text { Equation } \\
\text { number }\end{array}$ & Equation & $\begin{array}{c}\text { SER SEP } \\
\text { (in percent) }\end{array}$ \\
\hline
\end{tabular}

25 - year equations

(37)

$$
2 V_{25}=0.75(A)^{0.86}(P-30)^{0.35}(S L)^{0.17}(F+10)^{-0.14} \quad \pm 30.9 \quad \pm 33.1
$$

\section{0 - year equations}

(39)

$$
1 V_{50}=0.45(A)^{0.85}(P-30)^{0.37}(S L)^{0.24}(F+10)^{-0.20} \quad \pm 33.5 \quad \pm 35.7
$$

$$
2 V_{50}=0.88(A)^{0.87}(P-30)^{0.34}(S L)^{0.18}(F+10)^{-0.14} \quad \pm 30.8 \quad \pm 33.2
$$

$$
2 V_{100}=1.03(A)^{0.87}(P-30)^{0.33}(S L)^{0.19}(F+10)^{-0.14} \quad \pm 31.0 \quad \pm 33.4
$$


(variance inflation factor and condition number) indicate that the predictive ability of the equations is not appreciably affected by intercorrelation.

All equations were checked for parametrical and geographical bias. Parametrical bias was tested by plotting the residuals (differences between the synthesized and regression estimates) against each of the response and explanatory variables for all sites. The plots showed that the signs and magnitudes of the residuals varied randomly throughout the ranges of the response and explanatory variables, indicating that parametrical bias is not a problem.

To test for geographical bias, the residuals for each site were plotted by recurrence interval and duration on a State map at the corresponding location for that site. These plots were then inspected to determine if residuals of a given sign tended to cluster in any geographic region of the State for all durations and recurrence intervals. No geographical bias was apparent.

\section{Sensitivity Analysis}

Errors in measurement or judgment may occur when determining values for the physical and climatic variables (A, P, SL, and F). Consequently, a sensitivity analysis was performed to illustrate the effects of errors in these variables on the computations of flood volumes. The means of the four variables for the 62 study sites were calculated to be:

$$
\begin{aligned}
& A=1.06 \text { square miles, } \\
& P=37.9 \text { inches }, \\
& S L=87.5 \text { feet per mile, } \\
& F=9.0 \text { percent }
\end{aligned}
$$

These values were substituted into the 36 regression equations. Each explanatory variable was then varied from its mean in 5 -percent increments from -50 percent to +50 percent while the values of the other variables were held constant. The percent change in the explanatory variable was then plotted against the percent change in the computed volume. The results are presented in figure 8 . (Because all 36 plots were similar, only nine representative plots are shown.) Computed flood volumes will be least affected by changes in explanatory variables that plot closest to the horizontal axes in figure 8. Conversely, the computed flood volumes are most sensitive to changes in explanatory variables that plot farthest from the horizontal axes. For example, the sensitivity plots show that computed flood volumes are most sensitive to changes (or errors) in drainage area (A), followed by average annual precipitation $(\mathrm{P})$, main-channel slope (SL), and forested area (F).

\section{Application of the Volume-Duration- Frequency Equations}

The 36 volume-duration-frequency $\left(\mathrm{dV}_{\mathrm{T}}\right)$ equations provide a means for estimating volumes for selected durations and recurrence intervals at ungaged sites. The volumeduration-frequency equations for the desired recurrence interval can be applied to develop a relation between inflow volume and duration for an ungaged site. A theoretical maximumvolume hydrograph based on the volumeduration data can be constructed by converting the volume data as a function of duration to discharge data as a function of time and plotting the discharge data in a symmetrical pattern centered about the peak. This hydrograph can be used to develop a relation between inflow volume and time. This relation, in combination with an estimate of the relation between outflow volume and time for a hydraulic structure, can be used to develop an estimate of the relation between required storage and time. 

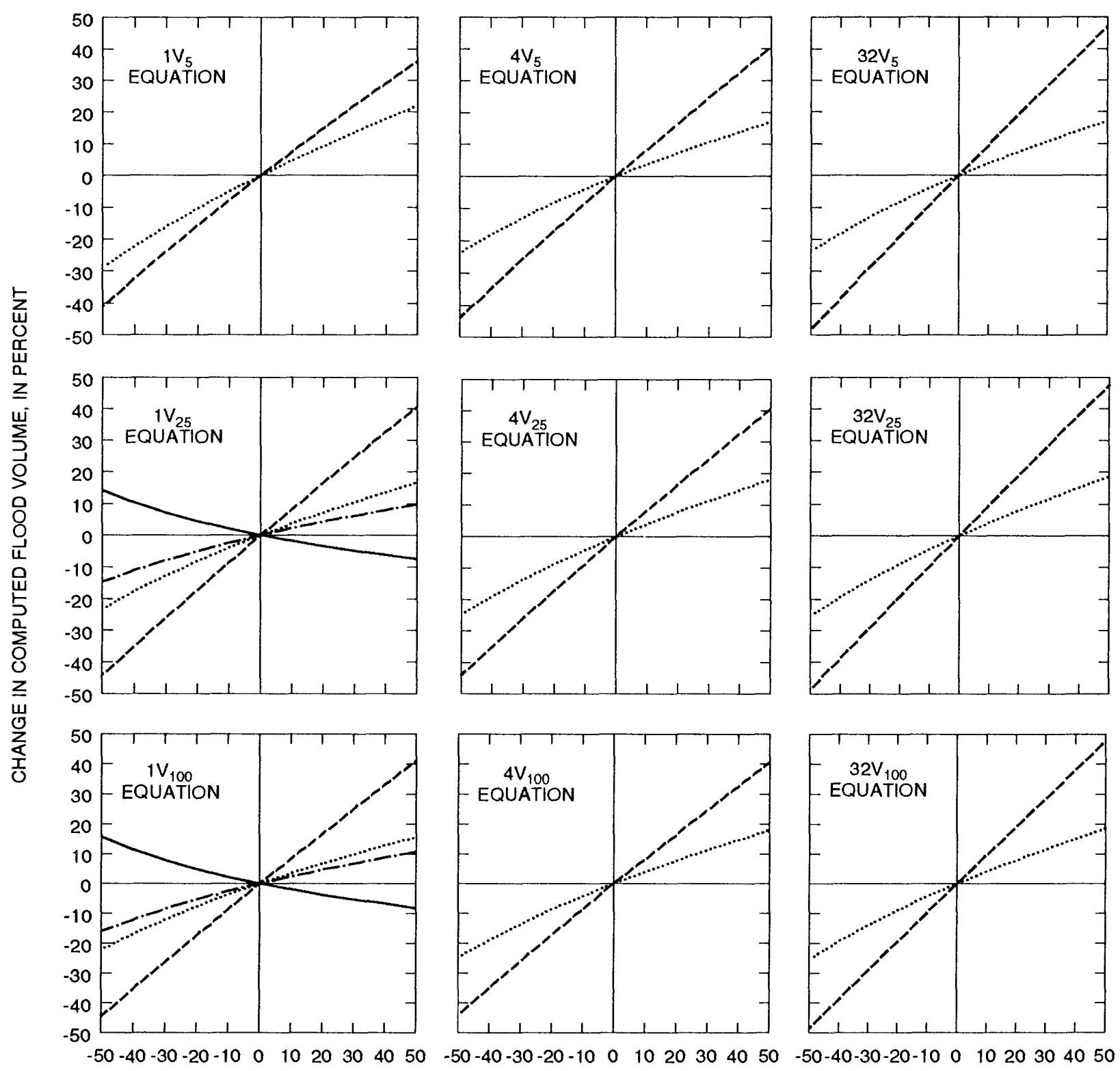

CHANGE IN EXPLANATORY VARIABLE, IN PERCENT

\section{EXPLANATION}

\section{DRAINAGE AREA}

MAIN-CHANNEL SLOPE

PRECIPITATION

FORESTED AREA

Figure 8.--Sensitivity of computed flood volumes to changes from the means of the explanatory variables in the volume-duration-frequency $\left(\mathrm{dV}_{\mathrm{T}}\right)$ equations for selected durations and recurrence intervals. 


\section{Limitations of the Method}

The 36 multiple-regression equations developed for estimating volume-durationfrequency relations are applicable to sites on small rural streams in Ohio which drain rural, undeveloped basins with no significant impervious areas, no channel improvements, and no sewers. The equations are applicable to sites having basin characteristics similar to the basin characteristics of the sites used in the regression analysis. The following table indicates the ranges of the basin characteristics of the study sites.

\begin{tabular}{cccl}
$\begin{array}{c}\text { Basin } \\
\text { charac- } \\
\text { teristic }\end{array}$ & $\begin{array}{c}\text { Mini- } \\
\text { mum }\end{array}$ & $\begin{array}{c}\text { Maxi- } \\
\text { mum }\end{array}$ & \multicolumn{1}{c}{ Unit } \\
\hline & & & \\
A & 0.026 & 6.45 & square miles \\
P & 31.5 & 42.8 & inches \\
SL & 7.60 & 462 & feet per mile \\
F & 0.0 & 97.4 & percent \\
\hline
\end{tabular}

Application of the equations to streams having basin characteristics outside of these ranges may result in errors that are considerably greater than those implied by the standard errors of prediction.

All study sites were chosen to have minimal basin storage (mean storage area for the 62 sites was 0.26 percent of the total drainage area; the maximum value was 3.1 percent).
The equations are not applicable to streams whose flood characteristics are significantly affected by storage or where upstream culverts or other structures may significantly reduce peak discharges by temporarily storing water behind them.

The percentage of area in a basin that has been surface-mined also may affect flood characteristics. In this study, 4 of the 62 basins had surface-mined areas $(6.1,12.8,33.4$, and 39.1 percent). This was not an adequate number of sites to perform any statistical analyses relating surface-mined area to flood volumes. Koltun and Roberts (1990) developed equations to estimate peak discharges of unregulated rural streams in Ohio on the basis of data from 275 basins, 45 of which had surfacemined areas ranging from 0.1 to 82.9 percent of the total basin area. In that study, tests for constant residual variance indicated a tendency for the equations to overestimate flood-peak discharges of streams draining basins with greater than 30 percent surface-mined area. Because of the relation between peak discharge and flood volume, the reader should use caution when applying the volume-duration-frequency equations to basins with greater than 30 percent surface-mined area because the uncertainties of the results may be larger for such basins.

It was assumed that annual peak volumes (for all durations) of small streams in Ohio are caused by rainfall falling on unfrozen ground. Data were collected and analyzed accordingly. The equations, therefore, should not be applied to streams where annual peak volumes are likely to be significantly affected by snowmelt or frozen ground. 


\section{Computation of Basin Characteristics}

The values of the basin characteristics are entered into the appropriate regression equations to compute the maximum volumes for the desired durations and recurrence intervals. The basin characteristics may be determined as follows:

A Drainage area (in square miles)--The drainage area contributing surface runoff to a specified location on a stream, measured in a horizontal plane. Computed by planimeter, digitizer, grid method, and so forth from U.S. Geological Survey 7.5-minute topographic quadrangle maps.

P Average annual precipitation (in inches)-Determined from an isohyetal map, shown in figure 9 (page 32), and published by the Ohio Department of Natural Resources (Harstine, 1991).

SL Main-channel slope (in feet per mile)-Computed as the difference in elevation (in feet) at points 10 and 85 percent of the distance along the main channel from a specified location on the channel to the topographic divide, divided by the channel distance (in miles) between the two points, as determined from U.S. Geological Survey 7.5-minute topographic quadrangle maps.

F Forested area (in percent)--The percentage of the total drainage area occupied by forest cover, as determined by measuring the green-tinted areas on U.S. Geological Survey 7.5-minute topographic quadrangle maps.

\section{Computation of Flood Volumes as a Function of Duration}

The following steps describe the procedure used to estimate volume-duration-frequency $\left(\mathrm{dV}_{\mathrm{T}}\right)$ relations of small rural streams in Ohio.

1. Determine the values of $A, P, S L$, and F, as described in "Computation of Basin Characteristics".

2. Check that the characteristics of the basin meet the criteria described in "Limitations of the Method".

3. Select the appropriate equations from tables 9 and 10 (p. 24-26) for the desired recurrence interval.

4. Substitute the values of $A, P, S L$, and F into the equations.

5. Compute the flood volumes.

6. Plot the flood volumes as a function of duration.

\section{Example of Computation of Flood Volume}

Estimate the 100-year flood volumes for all six durations for an ungaged rural stream in eastern Adams County, Ohio.

1. The following basin characteristics are determined:
$\mathrm{A}=0.59$ square miles
$\mathrm{P}=42.6$ inches
$\mathrm{SL}=82.3$ feet per mile
$\mathrm{F}=21.1$ percent

2. The basin characteristics meet the criteria described in "Limitations of the Method" (p. 29). 
3. The appropriate equations to be applied from tables 9 and 10 (p. 24-26) are:

$$
\begin{aligned}
1 \mathrm{~V}_{100} & =0.53(\mathrm{~A})^{0.85}(\mathrm{P}-30)^{0.36}(\mathrm{SL})^{0.25}(\mathrm{~F}+10)^{-0.21} \\
2 \mathrm{~V}_{100} & =1.03(\mathrm{~A})^{0.87}(\mathrm{P}-30)^{0.33}(\mathrm{SL})^{0.19}(\mathrm{~F}+10)^{-0.14} \\
4 \mathrm{~V}_{100} & =1.90(\mathrm{~A})^{0.84}(\mathrm{P}-30)^{0.41} \\
8 \mathrm{~V}_{100} & =2.92(\mathrm{~A})^{0.91}(\mathrm{P}-30)^{0.36} \\
16 \mathrm{~V}_{100} & =3.61(\mathrm{~A})^{0.95}(\mathrm{P}-30)^{0.36} \\
32 \mathrm{~V}_{100} & =3.77(\mathrm{~A})^{0.96}(\mathrm{P}-30)^{0.42}
\end{aligned}
$$

For this example, the alternate equations from table 10 are applied for estimating the 100-year flood volumes for the 1- and 2-hour durations, which may provide an improvement in accuracy over the 100-year 1- and 2-hour duration equations listed in table 9.

4. The basin characteristics are substituted into the equations:

$$
\begin{aligned}
1 \mathrm{~V}_{100} & =0.53(0.59)^{0.85}(42.6-30)^{0.36}(82.3)^{-0.25}(21.1+10)^{-0.21} \\
2 \mathrm{~V}_{100} & =1.03(0.59)^{0.87}(42.6-30)^{0.33}(82.3)^{-0.19}(21.1+10)^{0.14} \\
4 \mathrm{~V}_{100} & =1.90(0.59)^{0.84}(42.6-30)^{0.41} \\
8_{\mathrm{V} 100} & =2.92(0.59)^{0.91}(42.6-30)^{0.36} \\
16 \mathrm{~V}_{100} & =3.61(0.59)^{0.95}(42.6-30)^{0.36} \\
32 \mathrm{~V}_{100} & =3.77(0.59)^{0.96}(42.6-30)^{0.42}
\end{aligned}
$$

5. The estimated 100-year flood volumes are:

$$
\begin{aligned}
1 \mathrm{~V}_{100} & =1.23 \text { million cubic feet } \\
2 \mathrm{~V}_{100} & =2.15 \text { million cubic feet } \\
4 \mathrm{~V}_{100} & =3.45 \text { million cubic feet } \\
8 \mathrm{~V}_{100} & =4.50 \text { million cubic feet } \\
16 \mathrm{~V}_{100} & =5.44 \text { million cubic feet } \\
32 \mathrm{~V}_{100} & =6.58 \text { million cubic feet }
\end{aligned}
$$

6. The estimated volumes can then be plotted as a function of duration to yield a curve showing inflow volume as a function of duration as shown in figure 10. The lines connecting the symbols in figure 10 are for illustration purposes only.

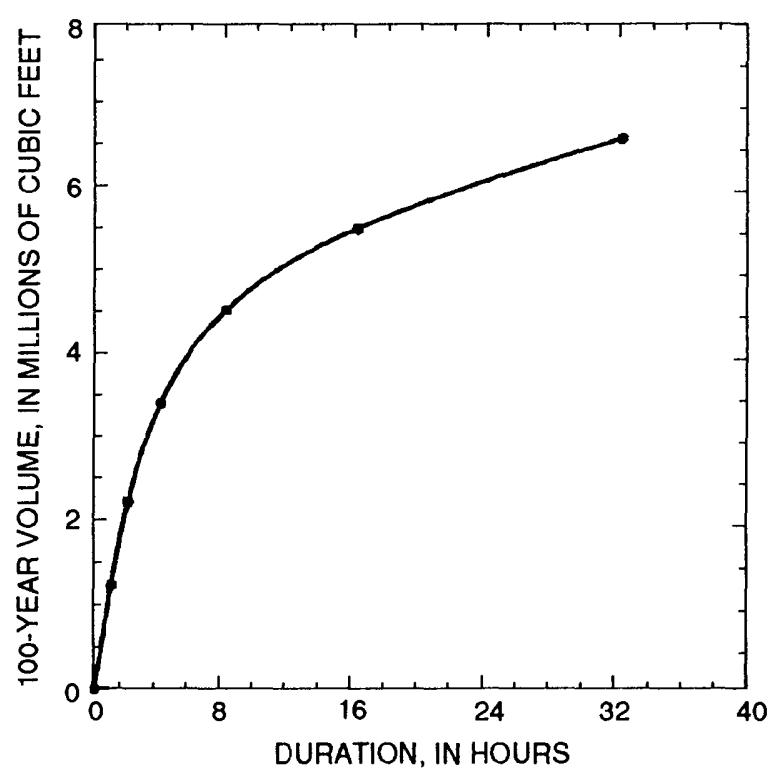

Figure 10.--Estimated 100-year volume as a function of duration for an ungaged rural stream in eastern Adams County, Ohio.

\section{Computation of Flood Volumes as a Function of Time}

Depending on the design application, it may be desirable to convert the volume data as a function of duration $\left(\mathrm{dV}_{\mathrm{T}}\right)$ to cumulative volume data as a function of time $\left(\mathrm{VQ}_{\mathrm{T}}(\mathrm{t})\right)$ for a hypothetical hydrograph having the same volume-duration characteristics. A method is illustrated in figure 11 that is based on the assumption of a hypothetical maximum-volume hydrograph which can be derived from the volume-duration data and constructed by converting the volume data as a function of duration to discharge data as a function of time 


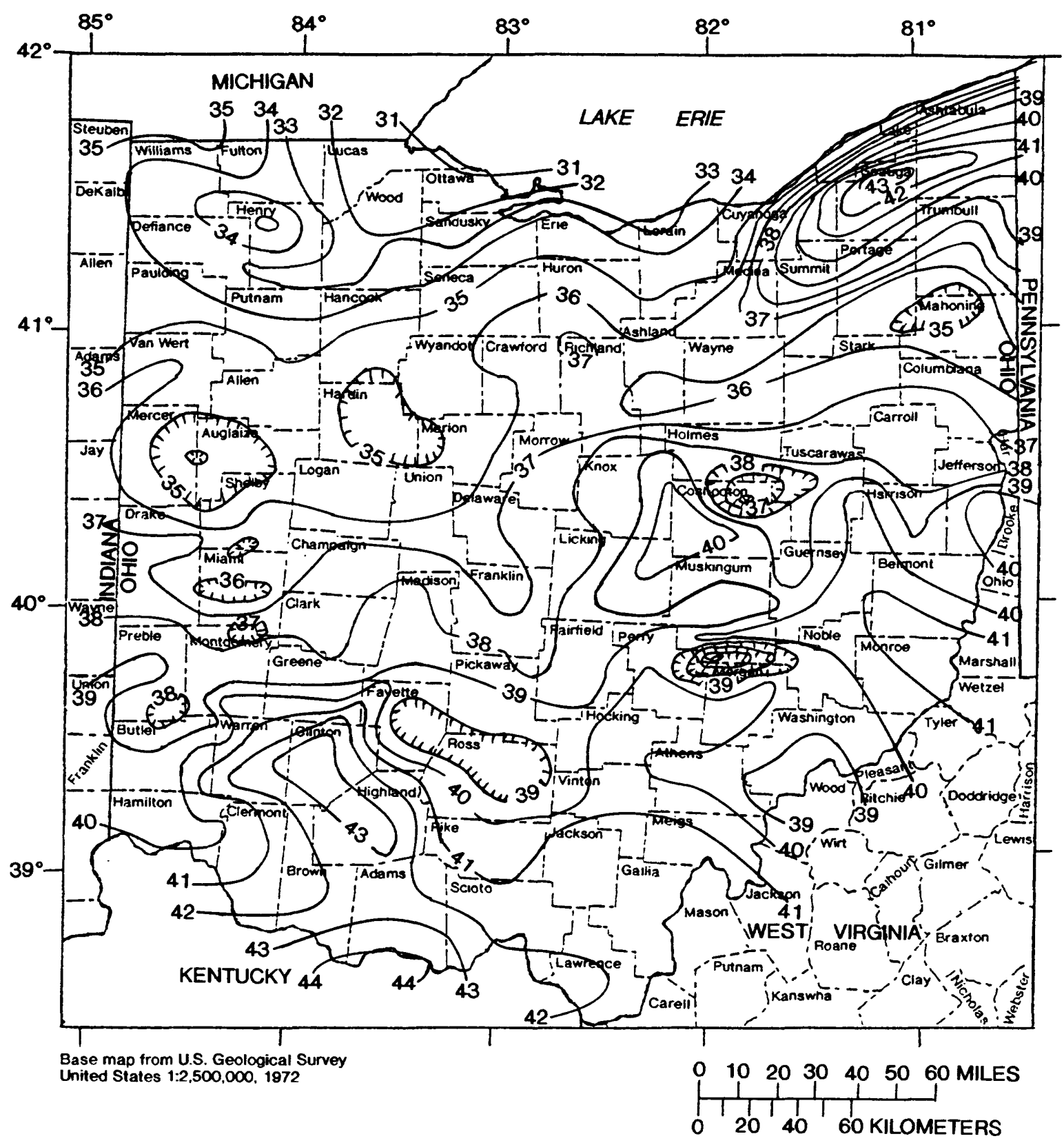

\section{EXPLANATION}

-34 LINE OF EQUAL AVERAGE ANNUAL PRECIPITATION--Hachured lines enclose areas of lesser precipitation. Interval is one-inch

Figure 9.--Average annual precipitation for Ohio for 1931-1980 (modified from Harstine, 1991). 
Table 11. Computations of cumulative volume as a function of time $\left(V Q_{T}(t)\right)$ from volume as a function of duration $\left(\mathrm{dV}_{\mathrm{T}}\right)$ for an ungaged rural stream in eastern Adams County, Ohio [d, duration (in hours); $t$, time (in hours); $\mathrm{dV}_{\mathrm{T}}$, volume (in millions of cubic feet) of $\mathrm{d}$ hours duration and $\mathrm{T}$ years recurrence interval; $\mathrm{VQ}_{\mathrm{T}}(\mathrm{t})$, cumulative volume (in millions of cubic feet) of $\mathrm{t}$ hours time and $\mathrm{T}$ years recurrence interval]

$\begin{array}{rcccccc}0 & 0.0 & V_{100}(0) & 0 V_{100} & 0 & 0 \\ 1 & 1.23 & \ldots & \end{array}$




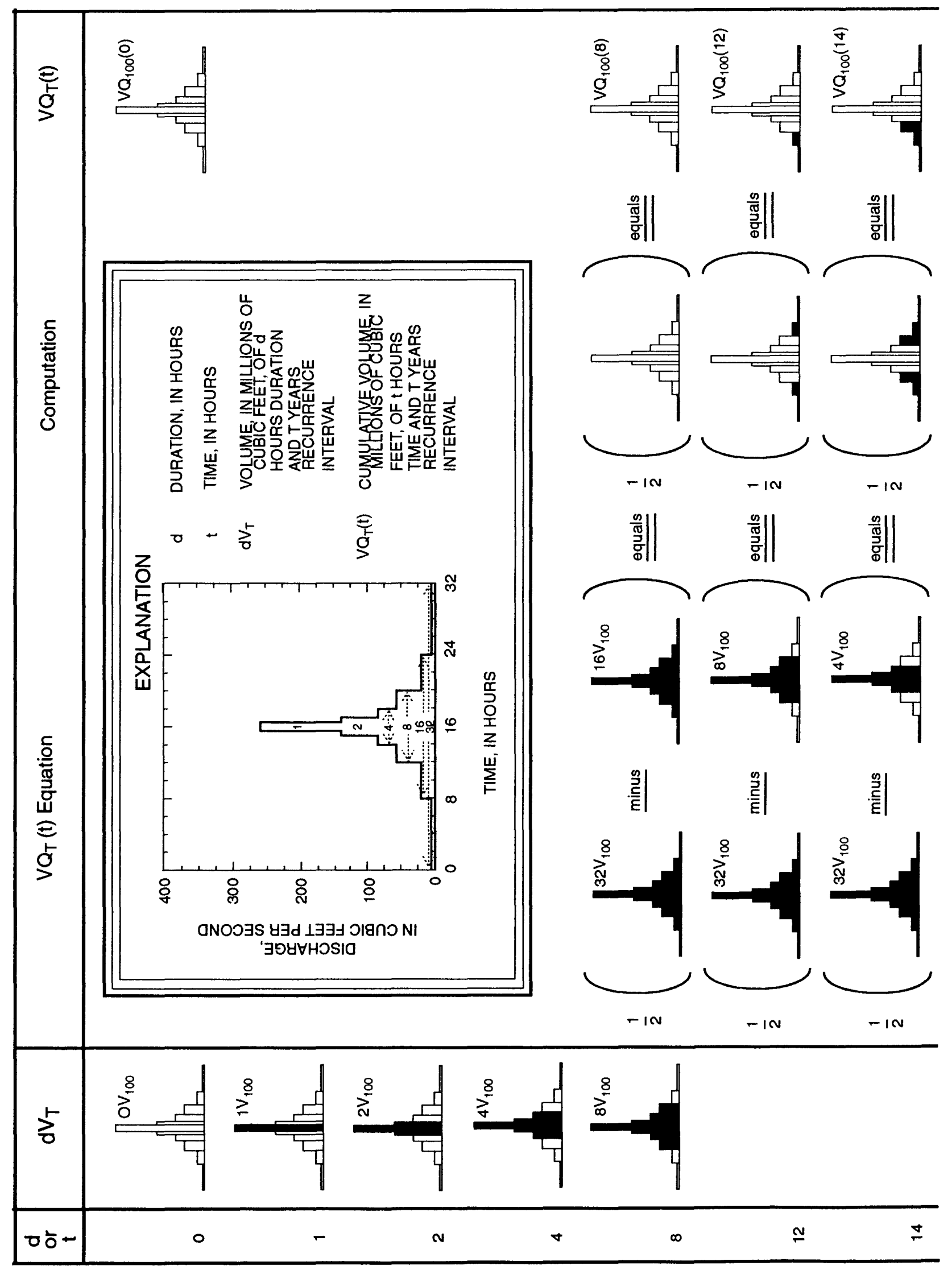




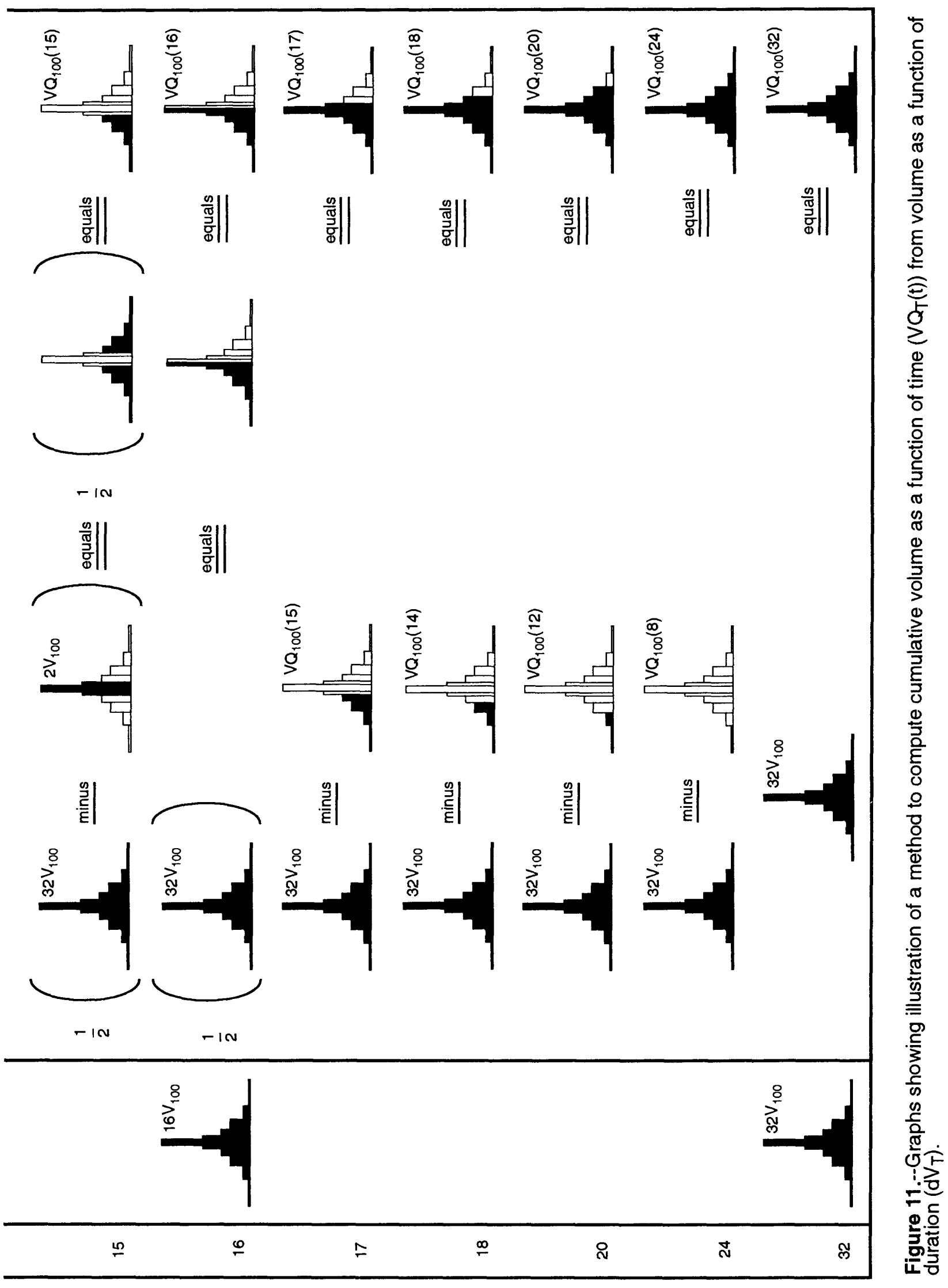


and plotting the discharge data in a symmetrical pattern centered about the peak. Computation of the $V Q_{T}(t)$ data from the $d_{V}$ data is shown in table 11 . The method, if applied, should be based on the entire 32-hour volumeduration-frequency curve. The cumulative volume data as a function of time $\left(\mathrm{VQ}_{\mathrm{T}}(\mathrm{t})\right)$ may then be plotted as shown in figure 12. The hydrograph in figure 11 is analogous to the hydrograph in figure 5 (page 15) which illustrates the selection of volumes for each of the six durations. To simplify the computations, however, the hydrograph in figure 11 has been constructed symmetrically and in a bar-graph shape. An actual hydrograph of such long duration would probably be asymmetrical. The figure 11 hydrograph is also based on the assumption that the maximum volumes for all six durations came from the same flood event. In fact, this is often, but not always, true (page 15). Thus, the cumulative volume data plotted in figure 12 is an approximation based on these assumptions.

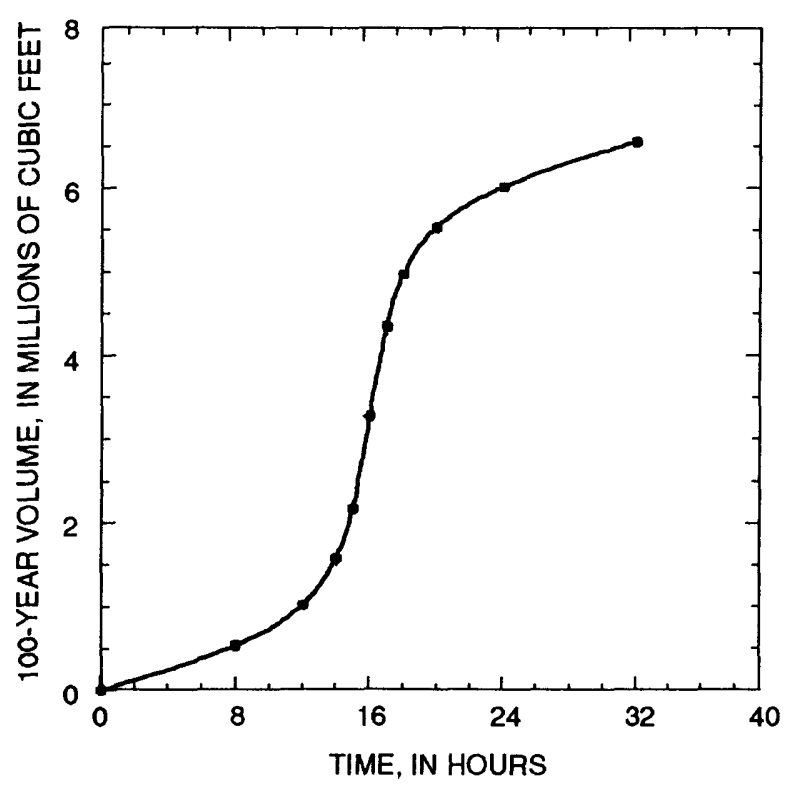

Figure 12.--Estimated 100-year volume as a function of time for an ungaged rural stream in eastern Adams County, Ohio.

\section{SIMULATION OF FLOOD HYDRO- GRAPHS AT UNGAGED RURAL SITES}

Simulated flood hydrographs provide a means of routing design peak discharges through a hydraulic structure so that outflow peak discharges from the structure may be estimated. A relatively simple technique for simulating flood hydrographs, in which estimated peak discharge for a specific recurrence interval and estimated basin lagtime (LT, defined in glossary) are applied to a dimensionless hydrograph, has been successfully applied in a national study (Stricker and Sauer, 1982) and also in several statewide studies (Inman, 1987; Robbins, 1986; Sherwood, 1986), and was selected for use in this study. Integration under the simulated hydrograph provides a volume estimate associated with the estimated peak discharge.

The dimensionless hydrograph is developed by first computing unit hydrographs for many observed flood hydrographs at many sites. The unit-hydrograph computation method is by O'Donnell (1960). These unit hydrographs are then reduced to dimensionless terms by dividing each discharge value by the peak discharge and each corresponding time value by the basin lagtime. The dimensionless hydrograph peaks are then aligned, and the discharge values are averaged for each 5-minute time increment to produce an average dimensionless hydrograph. The dimensionless hydrograph method is described in detail by Inman (1987).

The dimensionless hydrograph is based on streamflow and rainfall data. Rainfall data is included in its derivation, but not in its application. The method produces a typical (or average) hydrograph with a recurrence interval equal to the recurrence interval of the estimated peak discharge. Removal of rainfall from the application makes the dimensionless hydrograph method simple and easy to apply. The effects of rainfall duration on hydrograph 
duration are indirectly included, however, because of the effects of rainfall duration on basin lagtime, which is used in the application.

\section{Development of a Hydrograph-Simulation Technique for Ohio}

The development of a hydrographsimulation technique for Ohio consisted of (1) the use of equations developed by Koltun and Roberts (1990) to estimate peak discharge, (2) the development of an equation to estimate basin lagtime, and (3) the verification of a previously developed dimensionless hydrograph for use on small rural streams in Ohio.

\section{Estimation of Peak Discharge}

Use of the dimensionless hydrograph method for the simulation of flood hydrographs requires a value for peak discharge. Most design applications will use a peak discharge value associated with some specified recurrence interval. However, the method may also be used to fit the dimensionless hydrograph, to an actual peak discharge. In this case, the method will not reproduce the actual flood hydrograph, nor is it intended to; the simulated hydrograph will simply be an average hydrograph typical of average rainfall and antecedent conditions. If the peak discharge is to be estimated, equations developed by Koltun and Roberts (1990) are applicable.

In the study by Koltun and Roberts (1990), multiple-regression equations were developed to estimate peak discharges for rural unregulated basins in Ohio for specific recurrence intervals $\left(Q_{T}\right)$ as a function of basin characteristics (table 12). The equations were developed using data from 275 unregulated rural streams in Ohio and neighboring states whose drainage areas range from 0.01 to 7,422 square miles. Periods of record for the 275 sites ranged from 10 to 75 years, with a mean of 30 years. In order to eliminate any apparent geographical bias, the State is subdivided into three regions (fig. 13).
A scatter plot of residuals against drainage area for the 275 sites revealed no tendency to consistently overestimate or underestimate peak discharges for large or small drainage areas. Thus, the equations listed in table 12 should provide reliable estimates of peak discharge for large and small unregulated rural streams in Ohio.

\section{Estimation of Basin Lagtime}

Basin lagtime (LT) is generally defined as the time elapsed from the centroid of the rainfall excess (rainfall contributing to direct runoff) to the centroid of the resultant runoff hydrograph. LT was computed by use of computer programs developed by the Georgia District of the USGS (Inman, 1987). When applied to a dimensionless hydrograph, lagtime is used to define the width (time) of the hydrograph, whereas estimated peak discharge is used to define the height (discharge). The average basin lagtime for each of the 32 rural study basins was determined by averaging the lagtimes for the six largest (highest peak discharge) observed events at each site. Average basin lagtimes were then related to the basin characteristics of the 32 study sites (table 13) by multiple-regression analysis. The analysis resulted in the following equation:

$$
\mathrm{LT}=16.4(\mathrm{SL})^{-0.78}(\mathrm{~F}+10)^{0.39}(\mathrm{ST}+1)^{0.31}
$$

where

LT is basin lagtime (in hours),

SL is main-channel slope (in feet per mile),

$F$ is forested area (in percent) and,

ST is storage area (in percent).

The average standard error of regression is \pm 34.7 percent, and the average standard error of prediction is \pm 37.2 percent. SL and $\mathrm{F}$ are statistically significant at the 1-percent level, and ST is statistically significant at the 5-percent level. Bias tests indicated no apparent parametrical or geographical bias. 
Table 12. Equations for estimating peak discharges $\left(Q_{T}\right)$ of unregulated rural streams in Ohio. (from Koltun and Roberts, 1990)

[SEP, standard error of prediction]

\begin{tabular}{llll}
$\begin{array}{c}\text { Equation } \\
\text { number }\end{array}$ & & \multicolumn{1}{c}{ Equation } & $\begin{array}{c}\text { Average SEP } \\
\text { (in percent) }\end{array}$ \\
\hline$(43)$ & $Q_{2}=(R C)(A)^{0.782}(S L)^{0.172}(S T+1)^{-0.297}$ & 41.4 \\
$(44)$ & $Q_{5}=(R C)(A)^{0.769}(S L)^{0.221}(S T+1)^{-0.322}$ & 33.9 \\
$(45)$ & $Q_{10}=(R C)(A)^{0.764}(S L)^{0.244}(S T+1)^{-0.335}$ & 33.4 \\
$(46)$ & $Q_{25}=(R C)(A)^{0.760}(S L)^{0.264}(S T+1)^{-0.347}$ & 34.1 \\
$(47)$ & $Q_{50}=(R C)(A)^{0.757}(S L)^{0.276}(S T+1)^{-0.355}$ & 35.0 \\
$(48)$ & $Q_{100}=(R C)(A)^{0.756}(S L)^{0.285}(S T+1)^{-0.363}$ & 36.3 \\
& &
\end{tabular}

where RC is regression constant for region from the following matrix:

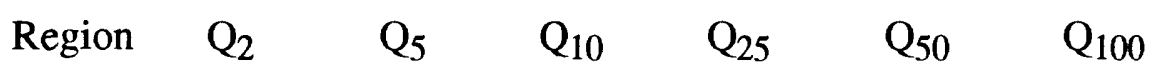

$\begin{array}{lrrrrrr}\text { A) } & 56.1 & 84.5 & 104 & 129 & 148 & 167 \\ \text { (B) } & 40.2 & 58.4 & 69.3 & 82.2 & 91.2 & 99.7 \\ \text { (C) } & 93.5 & 133 & 159 & 191 & 214 & 236\end{array}$

A is drainage area (in square miles),

SL is main-channel slope (in feet per mile), and

ST is storage area (in percent). 


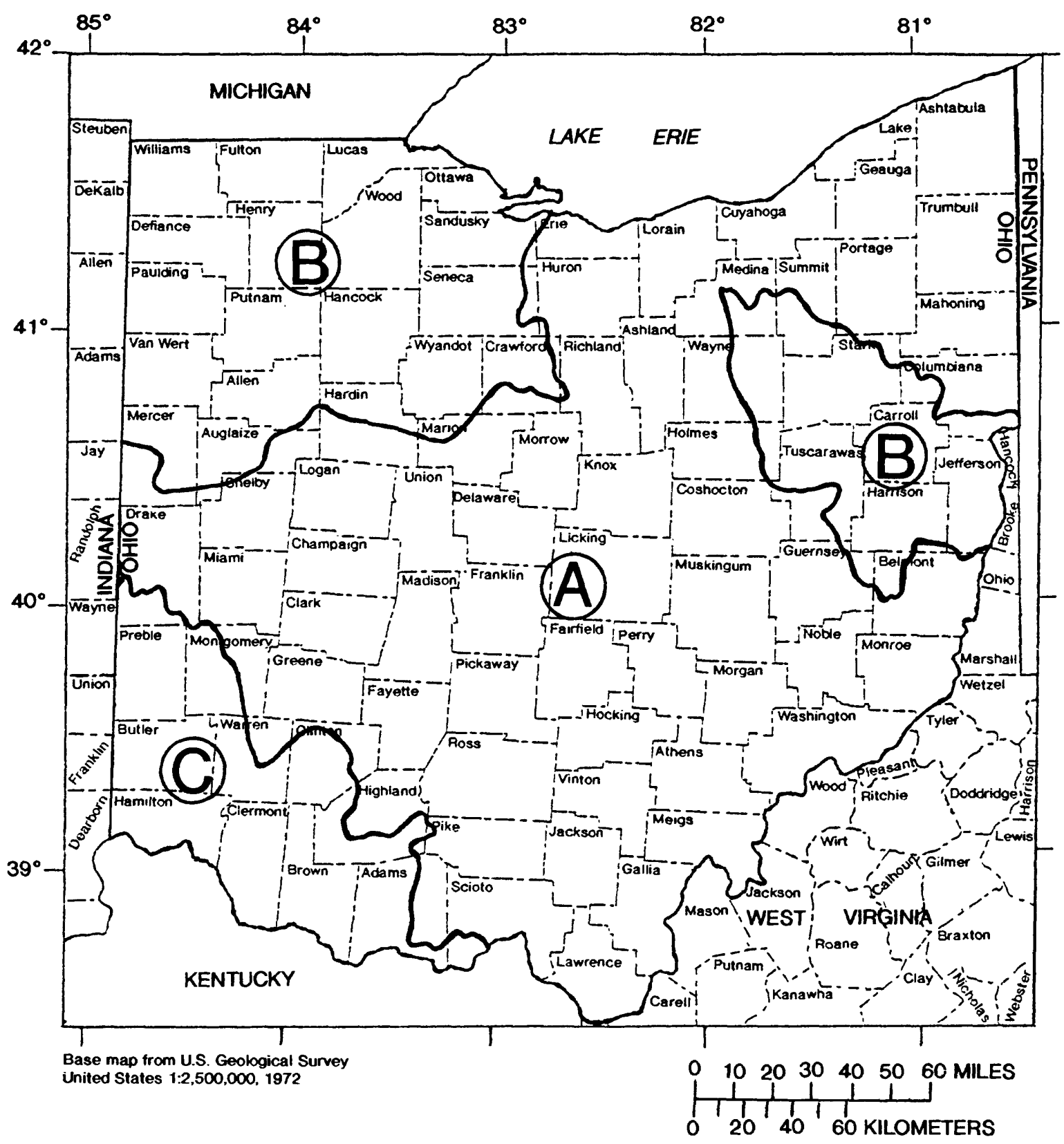

EXPLANATION

(A) recion

REGION BOUNDARY

Figure 13.--Region boundaries for peak-discharge equations (from Koltun and Roberts, 1990). 
A sensitivity analysis was performed to illustrate the effects of errors in SL, F, and ST on computations of basin lagtime. The mean values of SL ( $82.5 \mathrm{ft} / \mathrm{mi}), F(30.2$ percent), and ST ( 0.48 percent) were substituted into the lagtime equation, and each explanatory variable was then varied by 5 -percent increments from -50 percent to +50 percent while the values of the other explanatory variables were held constant. The percent change in the explanatory variable was then plotted against the percent change in the computed lagtime. The results are shown in figure 14 . The sensitivity of F and ST appears to be fairly constant, whereas SL appears to increase in sensitivity with a decrease in its value.

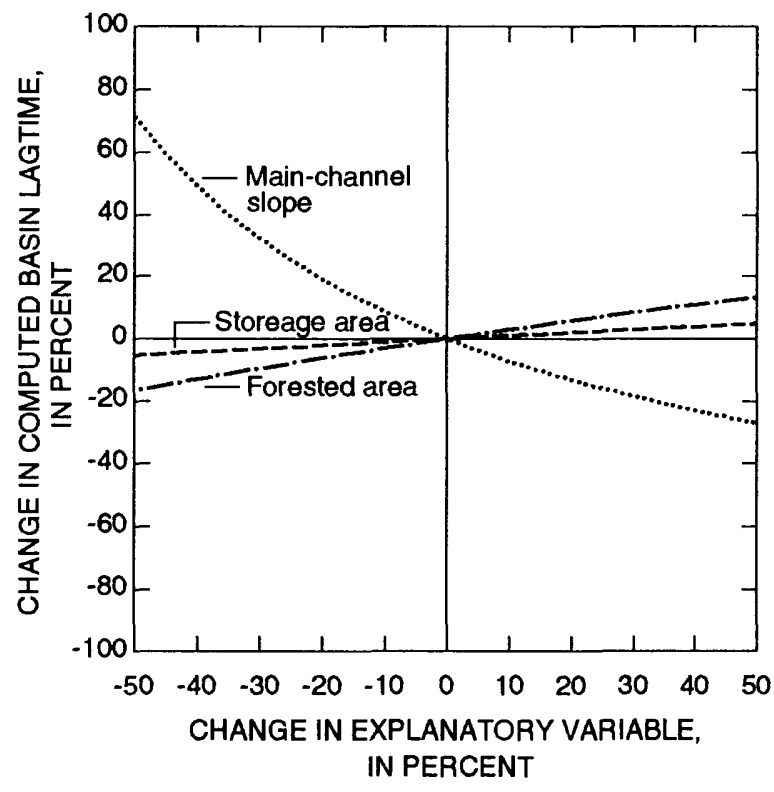

Figure 14.--Sensitivity of basin lagtime (LT) to changes from the means of the explanatory variables in the basin-lagtime equation.

LT apears to be relatively insensitive to changes in ST. This is because the mean value of ST for the 32 study sites is only 0.48 percent, and the range in values from -50 percent to +50 percent also is quite small $(0.24$ percent to 0.73 percent). Another sensitivity analysis was performed to show the effects of ST on basin lagtime (LT), peak discharge $\left(\mathrm{Q}_{\mathrm{p}}\right)$, and volume of the simulated hydrograph $\left(\mathrm{VQ}_{\mathrm{p}}\right)$ when $\mathrm{ST}$ is varied from 0 percent to 5 percent. This analysis provides a more useful illustration of the effects of ST on hydrograph shape and is presented and discussed further in the section following the hydrograph-simulation example.

As one would expect, the signs of the regression exponents of SL and ST are the opposite, in the lagtime equation to those in the peak-discharge equations. An increase in ST reduces the peak discharge while increasing lagtime, which results in an attenuated hydrograph which is longer and flatter. An increase in SL would have the opposite effect.

Likewise, the signs of the regression exponents of SL and F are the opposite in the lagtime equation to those in the short-duration volume equations. An increase in SL would cause a decrease in lagtime, which would steepen the hydrograph, increase peak discharge, and increase short-duration flood volumes. An increase in $\mathrm{F}$ would have the opposite effect.

\section{Selection and Verification of Dimensionless Hydrograph}

A dimensionless hydrograph is essentially a representative hydrograph shape for which the discharge is expressed as the ratio of discharge to peak discharge $\left(Q / Q_{p}\right)$, and the time as the ratio of time to lagtime ( $t / \mathrm{LT})$, as shown in figure 15 and table 14. It is developed by averaging typical hydrographs from a variety of basins. The hydrographs used in the analysis generally are single-peak events of average duration. Previous investigators have developed several dimensionless hydrographs, most of which are very similar. 
Table 13. Values of basin lagtime, main-channel slope, forested area, and storage area for 32 rural study sites in Ohio used in the basin lagtime multiple-regression analysis.

[LT, basin lagtime (in hours); SL, main-channel slope (in feet per mile); F, forested area (in percent); ST, storage area (in percent)]

$\begin{array}{llllll}\text { Station name } & \text { LT } & \text { SL } & \text { F } & \text { ST }\end{array}$

\begin{tabular}{|c|c|c|c|c|}
\hline 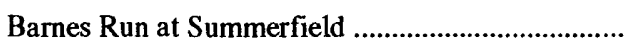 & 3.22 & 105 & 22.3 & 0.1 \\
\hline Browns Run near Crawford & 6.79 & 13.4 & 8.1 & .1 \\
\hline Bull Creek near Adelphi & 2.73 & 60.4 & 70.0 & 0.0 \\
\hline 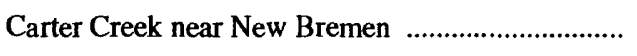 & 7.55 & 13.8 & 12.6 & 1.4 \\
\hline Cattail Creek at Baltic & .70 & 179 & 35.7 & 0.0 \\
\hline Chestnut Creek near Barnesville ................................. & 1.95 & 164 & 53.4 & .3 \\
\hline 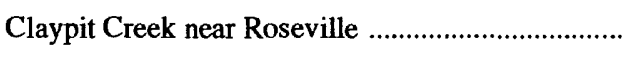 & 3.94 & 73.6 & 74.1 & 2.7 \\
\hline Delwood Run at Valley City & 2.30 & 45.1 & 5.1 & .4 \\
\hline Duncan Hollow Creek near McDermott......................... & 1.64 & 276 & 97.4 & 0.0 \\
\hline Dundee Creek at Dundee & 2.06 & 116 & 15.8 & 2.0 \\
\hline 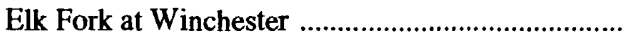 & 3.42 & 38.2 & 8.1 & .4 \\
\hline Elk Run near Alfred & 1.72 & 141 & 50.0 & 0.0 \\
\hline 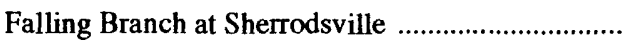 & 1.74 & 136 & 47.0 & 0.0 \\
\hline Fire Run at Auburn Corners & 3.01 & 124 & 67.9 & .8 \\
\hline Harte Run near Greenville & 4.93 & 20.2 & 5.2 & 0.0 \\
\hline Hoskins Creek at Hartsgrove & 15.4 & 21.8 & 39.0 & 3.1 \\
\hline King Run near Harrod & 1.46 & 65.0 & 10.0 & 0.0 \\
\hline Kitty Creek at Terre Haute & 4.93 & 39.2 & 4.9 & 0.0 \\
\hline March Run near West Point & 2.15 & 118 & 34.0 & 1.0 \\
\hline Racetrack Run at Hicksville & 1.84 & 30.8 & 7.4 & 0.0 \\
\hline Reitz Run at Waterville & 9.76 & 13.8 & 1.3 & 0.0 \\
\hline 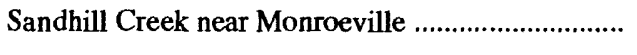 & 3.85 & 16.1 & 8.0 & .1 \\
\hline 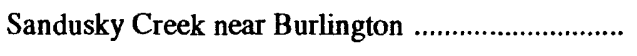 & 2.85 & 124 & 84.9 & 0.0 \\
\hline Second Creek near Marietta & 1.50 & 115 & 30.8 & .4 \\
\hline 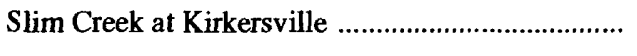 & 2.23 & 105 & 13.5 & 0.0 \\
\hline 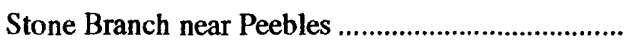 & 2.41 & 76.3 & 6.0 & 1.0 \\
\hline 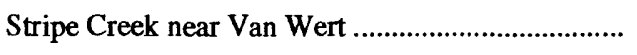 & 11.8 & 7.6 & 5.0 & 0.0 \\
\hline Sugar Run near New Market & 2.63 & 63.2 & 14.8 & .3 \\
\hline Tombstone Creek near Marysville ................................ & 5.36 & 21.1 & 10.9 & .5 \\
\hline Trippetts Branch at Camden & 1.78 & 145 & 37.9 & 6 \\
\hline 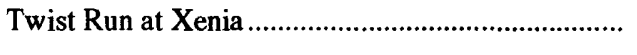 & 1.38 & 63.3 & 8.5 & .3 \\
\hline 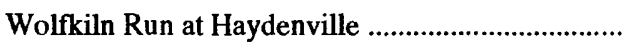 & 2.70 & 108 & 77.6 & 0.0 \\
\hline
\end{tabular}


A dimensionless hydrograph developed by the U.S. Geological Survey for use in Georgia (Inman, 1987) was selected for application in this study for several reasons:

1. The basins used in its development were similar in size and land use to the basins used in the Ohio study. was developed from 80 basins (61 rural, 19 urban), all of which had drainage areas of less than 20 square miles. The dimensionless hydrograph was verified for use on rural and urban streams in the Georgia study.

2. The Georgia dimensionless hydrograph has been verified for estimation of flood hydrographs on small urban streams in Ohio (Sherwood, 1993).

3. The method of lagtime computation used in development of the Georgia dimensionless hydrograph is the same as the method used in this study, in which basin lagtime is defined as the time elapsed from the centroid of the rainfall excess hyetograph to the centroid of the resultant runoff hydrograph.

4. The Georgia dimensionless hydrograph was verified for use in Tennessee (Robbins, 1986) for both urban and rural streams, which further supports its applicability in humid eastern states.

The Georgia dimensionless hydrograph was verified for use in Ohio by applying it to rainfall-runoff event data for the 32 rural study sites and performing an error analysis. Three observed hydrographs with the highest peak discharges from each study site were selected for analysis. The hydrographs selected differed from those used in the computations of average basin lagtime for each site so that verification would be provided from an independent data set. Three hydrographs were simulated for each site by applying the observed peak discharges for the three events and the average basin lagtime for the site to the Georgia dimensionless hydrograph. The 96 simulated hydrographs were then compared to the 96 observed hydrographs by computing the differences in hydrograph width at 50 percent $\left(\Delta \mathrm{W}_{50}\right)$ and 75 percent $\left(\Delta \mathrm{W}_{75}\right)$ of peak flow as shown in figure 16 . Root-meansquared errors at 50 percent and 75 percent of peak flow are 31.1 percent and 35.4 percent, respectively. These errors are comparable to the standard errors of estimate of \pm 39.5 percent $\left(\mathrm{W}_{50}\right)$ and $\pm 43.6\left(\mathrm{~W}_{75}\right)$ percent computed in the Georgia study verification.

The mean errors in discharge at 50 percent and 75 percent of peak flow were -5.0 percent and +8.7 percent. The Wilcoxon signed-ranks test indicated, however, that there was no statistically significant bias at the 1-percent level.

The coordinates of the dimensionless hydrograph developed by the Georgia District and verified for use in Ohio are listed in table 14 and plotted in figure 15 .

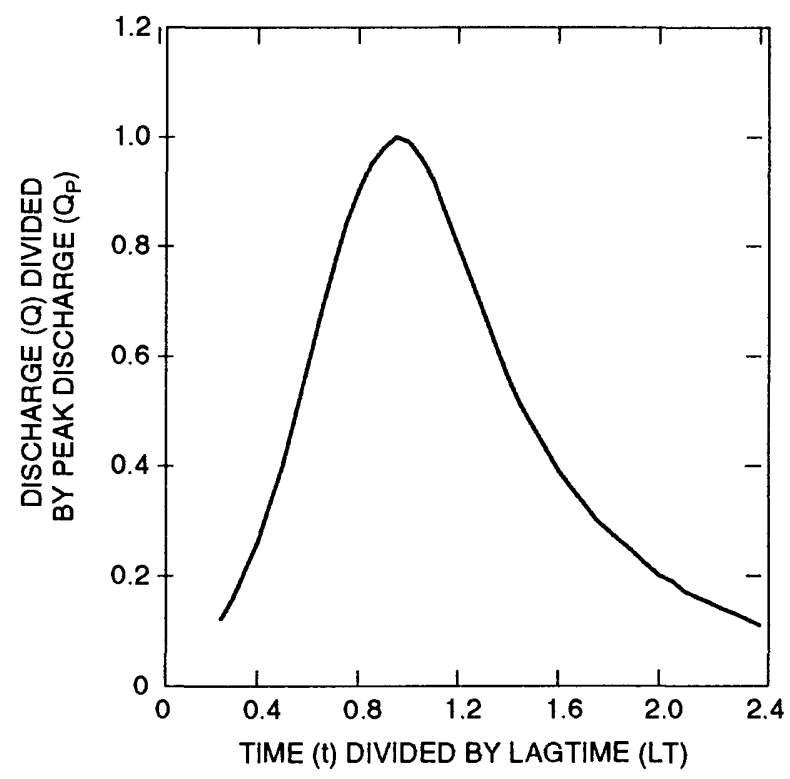

Figure 15.--Dimensionless hydrograph (from Inman, 1987). 
Table 14. Time and discharge ratios of the dimensionless hydrograph

[From Inman, 1987; t, time (in hours); LT, lagtime (in hours); $Q$, discharge (in cubic feet per second); and $Q_{p}$, peak discharge (in cubic feet per second)]

\begin{tabular}{|c|c|}
\hline $\begin{array}{r}\text { Time } \\
\text { ratio } \\
\text { (t/LT) }\end{array}$ & $\begin{array}{c}\text { Discharg } \\
\text { ratio } \\
\left(Q / Q_{p}\right)\end{array}$ \\
\hline $0.25 \ldots$ & 0.12 \\
\hline $.30 \ldots$ & .16 \\
\hline $.35 \ldots$ & .21 \\
\hline $.40 \ldots$ & .26 \\
\hline $.45 \ldots$ & .33 \\
\hline $.50 \ldots$ & $\ldots \ldots$. \\
\hline $.55 \ldots$ & $\ldots \ldots$ \\
\hline $.60 \ldots$ & $\ldots \ldots$ \\
\hline $.65 \ldots$ & $\ldots \ldots$ \\
\hline $.70 \ldots$ & $\ldots \ldots$. \\
\hline $.75 \ldots$ & $\ldots \ldots$ \\
\hline $.80 \ldots$ & ......... \\
\hline $.85 \ldots$ & $\ldots \ldots$ \\
\hline $.90 \ldots$ & $\ldots \ldots .$. \\
\hline $.95 \ldots$ & 1.00 \\
\hline $1.00 \ldots$ & .99 \\
\hline $1.05 \ldots$ & $\ldots \ldots$. \\
\hline $1.10 \ldots$ & ........ \\
\hline $1.15 \ldots$ & ......... \\
\hline $1.20 \ldots$ & $\ldots \ldots .$. \\
\hline $1.25 \ldots$ & $\ldots \ldots$ \\
\hline $1.30 \ldots$ & $\ldots . . .$. \\
\hline $1.35 \ldots$ & ........ \\
\hline $1.40 \ldots$ & .56 \\
\hline $1.45 \ldots$ & .51 \\
\hline $1.50 \ldots$ & $\ldots . .$. \\
\hline $1.55 \ldots$ & $\ldots \ldots$ \\
\hline $1.60 \ldots$ & ........ \\
\hline $1.65 \ldots$ & .36 \\
\hline $1.70 \ldots$ & $\ldots \ldots$ \\
\hline $1.75 \ldots$ & $\ldots \ldots$ \\
\hline $1.80 \ldots$ & .28 \\
\hline $1.85 \ldots$ & $\ldots . . .$. \\
\hline $1.90 \ldots$ & $\ldots . . .$. \\
\hline $1.95 \ldots$ & $\ldots . . .$. \\
\hline $2.00 \ldots$ & .......... \\
\hline $2.05 \ldots$ & $\ldots \ldots . .$. \\
\hline $2.10 \ldots$ & $\ldots \ldots$ \\
\hline $2.15 \ldots$ & $\ldots \ldots$. \\
\hline $2.20 \ldots$ & $\ldots$ \\
\hline $2.25 \ldots$ & $\ldots \ldots$ \\
\hline $2.30 \ldots$ & $\ldots \ldots .$. \\
\hline $2.35 \ldots$ & .12 \\
\hline $2.40 \ldots$ & .11 \\
\hline
\end{tabular}

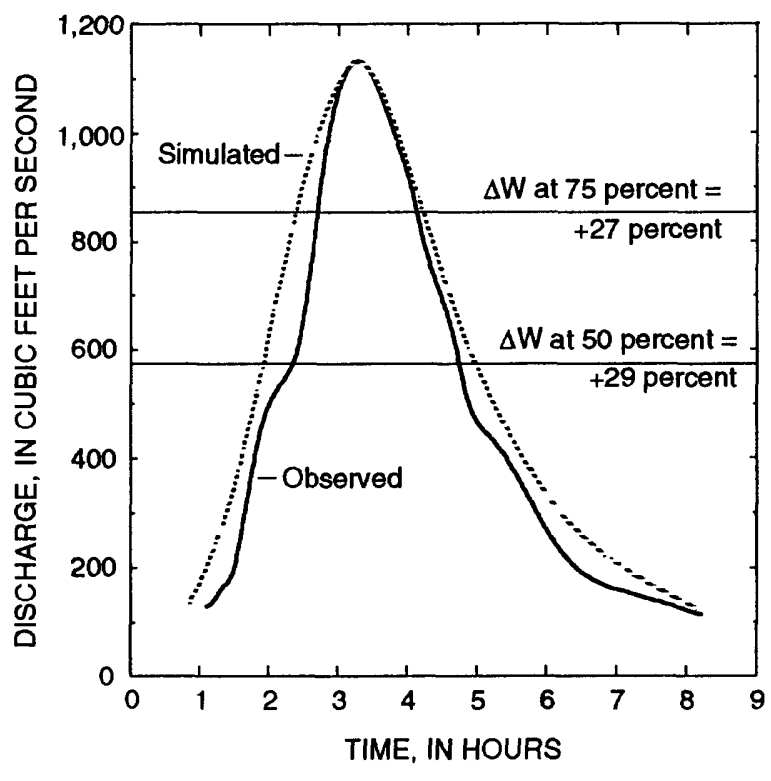

Figure 16.--Observed and simulated hydrographs and respective differences in hydrograph widths $(\Delta W)$ at 75 and 50 percent of peak discharge for flood event of May 30, 1982, on Elk Fork at Winchester, Ohio.

\section{Application of the Hydrograph-Simulation Technique}

The following sections describe a technique for simulating flood hydrographs for a specified peak discharge. Estimated basin lagtime (LT) and peak discharge $\left(\mathrm{Q}_{\mathrm{p}}\right)$ are applied to a dimensionless hydrograph to simulate a flood hydrograph for the given peak discharge. If the peak discharge is to be estimated, equations 43 to 48 (table 12 , page 38) may be applied.

Because the dimensionless hydrograph was developed from events of about average duration, the procedure outlined above will generate a simulated hydrograph of about average duration. The reader is cautioned, however, that actual hydrographs having the same peak discharge but with considerably longer duration (and greater volume) also are possible. 


\section{Limitations of the Method}

The method is limited to ungaged sites that have basin characteristics similar to the 32 rural gaged sites used in the lagtime regression analysis and dimensionless-hydrograph verification.

The ranges of the explanatory variables in the peak and lagtime equations are listed in the following table.

\begin{tabular}{lccl}
\hline $\begin{array}{l}\text { Vari- } \\
\text { ble }\end{array}$ & $\begin{array}{c}\text { Mini- } \\
\text { mum }\end{array}$ & $\begin{array}{c}\text { Maxi- } \\
\text { mum }\end{array}$ & Unit \\
\hline & & & \\
A & 0.13 & 6.45 & square miles \\
SL & 7.60 & 276 & feet per mile \\
F & 1.30 & 97.4 & percent \\
ST & 0.00 & 3.10 & percent \\
\hline
\end{tabular}

Application of the method to streams having basin characteristics outside of these ranges may result in errors that are considerably greater than those implied by the error analyses.

The 32 rural study sites were chosen to have minimal ( 0 to 3.1 percent) storage area. Because the peak-discharge equations and basin-lagtime equation are quite sensitive to storage, it is important that the method not be applied to streams with values of ST greater than 3.1 percent.

In the study documented by Koltun and Roberts (1990), tests for constant residual variance indicated that the peak-discharge equations developed in that study have a tendency to overestimate flood-peak discharges when applied to streams draining basins with greater than 30 percent surface-mined area. Caution should, therefore, be used when applying the hydrograph simulation method to basins with greater than 30 percent surface-mined area.

\section{Computation of Basin Characteristics}

The values of the basin characteristics of the ungaged site are entered into the appropriate regression equations to compute peak discharge for the desired recurrence interval and basin lagtime. They may be determined as follows:

A Drainage area (in square miles)--The drainage area contributing surface runoff to a specified location on a stream, measured in a horizontal plane and enclosed by a topographic divide. Computed (by planimeter, digitizer, grid method, and so forth) from U.S. Geological Survey 7.5-minute topographic quadrangle maps.

SL Main-channel slope (in feet per mile)-Computed as the difference in elevation (in feet) at points 10 and 85 percent of the distance along the main channel from a specified location on the channel to the topographic divide for the contributing drainage area, divided by the channel distance (in miles) between the two points, as determined from U.S.Geological Survey 7.5 -minute topographic quadrangle maps.

F Forested area (in percent)--The percentage of the total drainage area occupied by forest cover, as determined by measuring the green-tinted areas on U.S. Geological Survey 7.5-minute topographic quadrangle maps.

ST Storage area (in percent)--The percentage of total drainage area occupied by lakes, ponds, and swamps as determined by measuring those areas on U.S. Geological Survey 7.5-minute topographic quadrangle maps. The storage capacity (current, available, or maximum) is not a factor when making this measurement. 


\section{Computation of Peak Discharge}

The following procedure may be used if it is necessary to estimate the peak discharge for the purpose of hydrograph estimation.

1. Determine the values of $\mathrm{A}, \mathrm{SL}$, and ST, as described in the previous section.

2. Check that the characteristics of the basin meet the criteria described in "Limitations of the Method" (p. 44).

3. Select the appropriate equation from table 12 (p. 38) for the desired recurrence interval.

4. Substitute the computed values of A, SL, and ST into the equation.

5. Compute the peak discharge.

\section{Computation of Basin Lagtime}

The following procedure should be used for estimating the basin lagtime of small rural streams in Ohio.

1. Determine the values of SL, F, and ST, as described in "Computation of Basin Characteristics" (p. 44).

2. Check that the characteristics of thebasin meet the criteria described in "Limitations of the Method" (p. 44).

3. Substitute the values of SL, F, and ST into equation 49 (p. 37).

4. Compute the basin lagtime.

\section{Computation and Plotting of Flood Hydrograph}

The following procedure may be used to simulate flood hydrographs for a specific peak discharge for small rural streams in Ohio.

1. If it is necessary to estimate the peak discharge $\left(Q_{p}\right)$, use the procedure described in "Computation of Peak Discharge".

2. Estimate the basin lagtime (LT) using the procedure described in "Computation of Basin Lagtime".

3. Multiply each value of $\mathrm{t} / \mathrm{LT}$ in table 14 (p.43) by LT. These computed values are the time $(\mathrm{t})$ coordinates of the hydrograph: $t=(t / L T)(L T)$.

4. Multiply each value of $Q / Q_{p}$ in table 14 (p. 43) by $Q_{p}$. These computed values are the corresponding discharge $(Q)$ coordinates of the hydrograph: $Q=\left(Q / Q_{p}\right)\left(Q_{p}\right)$.

5. Plot time $(\mathrm{t})$ against discharge $(\mathrm{Q})$.

\section{Example of Computation of Flood Hydrograph}

Simulate the flood hydrograph of the estimated 100-year flood for an ungaged rural stream in eastern Adams County, Ohio (region A) where:

$$
\begin{aligned}
\mathrm{A} & =0.59 \text { square miles } \\
\mathrm{SL} & =82.3 \text { per mile } \\
\mathrm{F} & =21.1 \text { percent } \\
\mathrm{ST} & =0.3 \text { percent }
\end{aligned}
$$

These values are within the ranges of the explanatory variables used in the development of the hydrograph-simulation method. 
1. The 100-year flood peak discharge is estimated by use of equation 48 (table 12, page 38 ).

$$
\begin{aligned}
& \mathrm{Q}_{100}=(\mathrm{RC})(\mathrm{A})^{0.756}(\mathrm{SL})^{0.285}(\mathrm{ST}+1)^{-0.363} \\
& \mathrm{Q}_{100}=167(0.59)^{0.756}(82.3)^{0.285}(0.3+1)^{-0.363} \\
& \mathrm{Q}_{100}=358 \text { cubic feet per second }
\end{aligned}
$$

2. The basin lagtime is estimated by use of equation 49 (p. 37).

$$
\begin{aligned}
& \mathrm{LT}=16.4(\mathrm{SL})^{-0.78}(\mathrm{~F}+10)^{0.39}(\mathrm{ST}+1)^{0.31} \\
& \mathrm{LT}=16.4(82.3)^{-0.78}(21.1+10)^{0.39}(0.3+1)^{0.31} \\
& \mathrm{LT}=2.18 \text { hours }
\end{aligned}
$$

3. Each value of $t / L T$ in table 14 is multiplied by 2.18 hours. (Results are presented in table 15.)

4. Each value of $Q / Q_{p}$ in table 14 is multiplied by 358 cubic feet per second (the estimated 100-year peak discharge). (Results are presented in table 15.)

5. Time $(\mathrm{t})$ versus discharge $(\mathrm{Q})$ is plotted (figure 17).

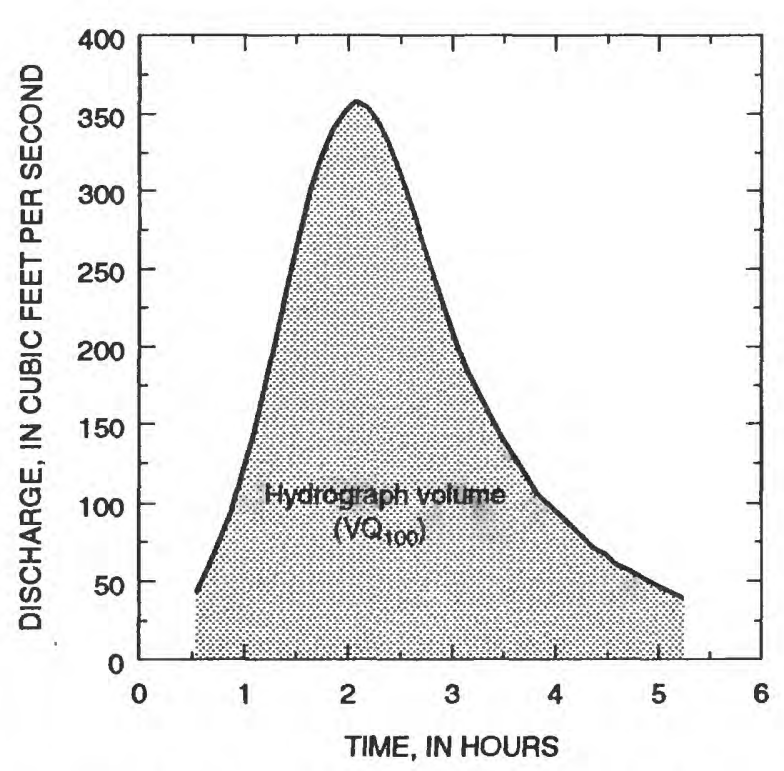

Figure 17.--Simulated flood hydrograph of estimated 100-year peak discharge for an ungaged rural stream in eastern Adams County, Ohio.

\section{Computation of Hydrograph Volume}

Flood volume corresponding to the simulated hydrograph may be computed by numerically integrating the area under the hydrograph or by use of an equation developed in this section. The computed volume is an average or typical volume for the design-peak discharge.

The cumulative volume (VQ) indicated in table 15 is computed by multiplying the timeratio increment $(0.05)$ times the lagtime ( 2.18 hours) times 3,600 seconds per hour times the mean discharge $(\mathrm{Q})$ for the time increment as shown in the following example for the first increment.

$$
\begin{aligned}
& V Q=(.05)(2.18)(3,600)[(43.0+57.3) / 2] \\
& V Q=19,700 \text { cubic feet }
\end{aligned}
$$

These values are summed to compute the total volume $\left(\mathrm{VQ}_{100}\right)$ of $2,930,000$ cubic feet. The total volume, which is indicated by the shaded area in figure 17, does not include the volume under the "tails" of the hydrograph, which generally is considered insignificant. To quickly compute the total volume $\left(\mathrm{VQ}_{\mathrm{p}}\right)$ from peak and lagtime, use the following equation:

$$
\mathrm{VQ}_{\mathrm{p}}=3,750\left(\mathrm{Q}_{\mathrm{p}}\right)(\mathrm{LT})
$$

where:

$\mathrm{VQ}_{\mathrm{p}}$ is hydrograph volume of $\mathrm{Q}_{\mathrm{p}}$ (in cubic feet);

$Q_{p}$ is peak discharge (in cubic feet per second); and

LT is basin lagtime (in hours).

The constant $(3,750)$ in equation 50 is the difference between the last and first time ratios $(2.40-0.25=2.15)$ times 3,600 seconds per hour times the mean of the incremental discharge ratios $(0.484)$ :

$$
(2.15)(3,600)(0.484)=3,750 \text {. }
$$

Example:

$$
\begin{aligned}
\mathrm{VQ}_{100} & =3,750\left(\mathrm{Q}_{100}\right)(\mathrm{LT}) \\
\mathrm{VQ}_{100} & =3,750(358)(2.18) \\
\mathrm{VQ}_{100} & =2,930,000 \text { cubic feet }
\end{aligned}
$$


Table 15. Computation of simulated hydrograph and integration of flood volume of estimated 100-year peak discharge for an ungaged rural stream in eastern Adams County, Ohio $\left[\mathrm{ft}^{3}\right.$, cubic feet; $\mathrm{ft}^{3} / \mathrm{sec}$, cubic feet per second]

\begin{tabular}{|c|c|c|c|c|c|c|}
\hline t/LT & LT & $=$ & $Q / Q p$ & Qp & $\mathbf{Q}$ & Vo \\
\hline $\begin{array}{l}\text { Time } \\
\text { ratio }\end{array}$ & $\begin{array}{l}\text { From } \\
\text { step } 2\end{array}$ & $\begin{array}{l}\text { Time, } \\
\text { hours }\end{array}$ & $\begin{array}{c}\text { Discharge } \\
\text { ratio }\end{array}$ & $\begin{array}{l}\text { From } \\
\text { step } 1\end{array}$ & $\begin{array}{l}\text { Discharge, } \\
\mathrm{ft}^{3} / \mathrm{sec}\end{array}$ & $\begin{array}{l}\text { Cumulative } \\
\text { volume, } \mathrm{ft}^{3}\end{array}$ \\
\hline 0.25 & 2.18 & 0.54 & 0.12 & 358 & 43.0 & 0 \\
\hline .30 & 2.18 & .65 & .16 & 358 & 57.3 & 19,700 \\
\hline .35 & 2.18 & .76 & .21 & 358 & 75.2 & 45,700 \\
\hline .40 & 2.18 & .87 & .26 & 358 & 93.1 & 78,700 \\
\hline .45 & 2.18 & .98 & .33 & 358 & 118 & 120,000 \\
\hline .50 & 2.18 & 1.09 & .40 & 358 & 143 & 171,000 \\
\hline .55 & 2.18 & 1.20 & .49 & 358 & 175 & 234,000 \\
\hline .60 & 2.18 & 1.31 & .58 & 358 & 208 & 309,000 \\
\hline .65 & 2.18 & 1.42 & .67 & 358 & 240 & 397,000 \\
\hline .70 & 2.18 & 1.53 & .76 & 358 & 272 & 497,000 \\
\hline .75 & 2.18 & 1.63 & .84 & 358 & 301 & 610,000 \\
\hline .80 & 2.18 & 1.74 & .90 & 358 & 322 & 732,000 \\
\hline .85 & 2.18 & 1.85 & .95 & 358 & 340 & 862,000 \\
\hline .90 & 2.18 & 1.96 & .98 & 358 & 351 & 997,000 \\
\hline .95 & 2.18 & 2.07 & 1.00 & 358 & 358 & $1,140,000$ \\
\hline 1.00 & 2.18 & 2.18 & .99 & 358 & 354 & $1,280,000$ \\
\hline 1.05 & 2.18 & 2.29 & .96 & 358 & 344 & $1,410,000$ \\
\hline 1.10 & 2.18 & 2.40 & .92 & 358 & 329 & $1,550,000$ \\
\hline 1.15 & 2.18 & 2.51 & .86 & 358 & 308 & $1,670,000$ \\
\hline 1.20 & 2.18 & 2.62 & .80 & 358 & 286 & $1,790,000$ \\
\hline 1.25 & 2.18 & 2.72 & .74 & 358 & 265 & $1,890,000$ \\
\hline 1.30 & 2.18 & 2.83 & .68 & 358 & 243 & $1,990,000$ \\
\hline 1.35 & 2.18 & 2.94 & .62 & 358 & 222 & $2,090,000$ \\
\hline 1.40 & 2.18 & 3.05 & .56 & 358 & 200 & $2,170,000$ \\
\hline 1.45 & 2.18 & 3.16 & .51 & 358 & 183 & $2,240,000$ \\
\hline 1.50 & 2.18 & 3.27 & .47 & 358 & 168 & $2,310,000$ \\
\hline 1.55 & 2.18 & 3.38 & .43 & 358 & 154 & $2,380,000$ \\
\hline 1.60 & 2.18 & 3.49 & .39 & 358 & 140 & $2,430,000$ \\
\hline 1.65 & 2.18 & 3.60 & .36 & 358 & 129 & $2,490,000$ \\
\hline 1.70 & $\cdot 2.18$ & 3.71 & .33 & 358 & 118 & $2,530,000$ \\
\hline 1.75 & 2.18 & 3.81 & .30 & 358 & 107 & $2,580,000$ \\
\hline 1.80 & 2.18 & 3.92 & .28 & 358 & 100 & $2,620,000$ \\
\hline 1.85 & 2.18 & 4.03 & .26 & 358 & 93.1 & $2,660,000$ \\
\hline 1.90 & 2.18 & 4.14 & .24 & 358 & 85.9 & $2,690,000$ \\
\hline 1.95 & 2.18 & 4.25 & .22 & 358 & 78.8 & $2,720,000$ \\
\hline 2.00 & 2.18 & 4.36 & .20 & 358 & 71.6 & $2,750,000$ \\
\hline 2.05 & 2.18 & 4.47 & .19 & 358 & 68.0 & $2,780,000$ \\
\hline 2.10 & 2.18 & 4.58 & .17 & 358 & 60.9 & $2,810,000$ \\
\hline 2.15 & 2.18 & 4.69 & .16 & 358 & 57.3 & $2,830,000$ \\
\hline 2.20 & 2.18 & 4.80 & .15 & 358 & 53.7 & $2,850,000$ \\
\hline 2.25 & 2.18 & 4.90 & .14 & 358 & 50.1 & $2,870,000$ \\
\hline 2.30 & 2.18 & 5.01 & .13 & 358 & 46.5 & $2,890,000$ \\
\hline 2.35 & 2.18 & 5.12 & .12 & 358 & 43.0 & $2,910,000$ \\
\hline 2.40 & 2.18 & 5.23 & .11 & 358 & 39.4 & $2,930,000$ \\
\hline
\end{tabular}


The duration (D) of the simulated hydrograph may be computed by use of the following equation:

$$
\mathrm{D}=2.15(\mathrm{LT})
$$

where:

$\mathrm{D}$ is hydrograph duration (in hours); and

LT is basin lagtime (in hours).

The constant (2.15) in equation 51 is the difference between the last and first time ratios $(2.40-0.25=2.15)$.

Example:

$$
\begin{aligned}
& \mathrm{D}=2.15(\mathrm{LT}) \\
& \mathrm{D}=2.15(2.18) \\
& \mathrm{D}=4.69 \text { hours }
\end{aligned}
$$

\section{Effects of Storage Area on Hydrograph Simulation}

The value of storage area has a significant effect on the simulation of flood hydrographs. The effects of storage area (ST) on peak discharge $\left(\mathrm{Q}_{100}\right)$, basin lagtime (LT), and flood volume $\left(\mathrm{VQ}_{100}\right)$ when simulating 100 -year flood hydrographs are shown in figure 18 . $\mathrm{Q}_{100}$, LT, and $\mathrm{VQ}_{100}$ were computed for a hypothetical 100 -year flood hydrograph for storage-area values of 0 through 5 percent. As shown in the figure, compared to a storagearea value of 0 percent, a storage-area value of 3.0 percent would decrease $\mathrm{Q}_{100}$ by 40 percent, increase LT by 54 percent, and decrease $\mathrm{VQ}_{100}$ by 7 percent. Thus, while it is important to be careful when measuring storage because it has a substantial effect on peak discharge and basin lagtime, the actual impact of storage on flood volume is much less. The vertical dashed line in figure 18 indicates the upper limit for ST (3.1 percent) for use in the hydrograph-simulation technique. The technique has not been verified for basins with more than 3.1-percent storage area.

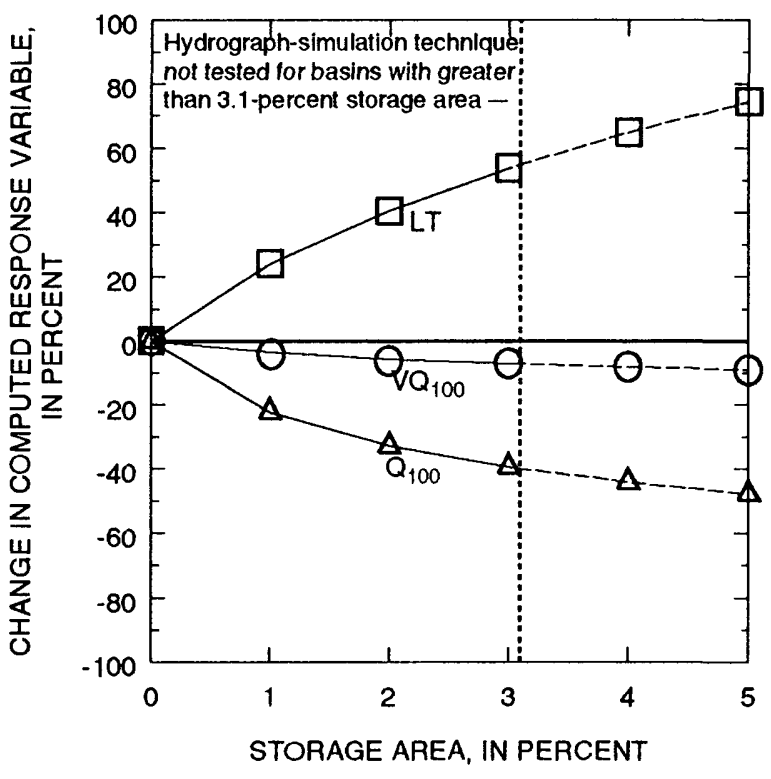

Figure 18.--Sensitivities of peak discharge $\left(Q_{100}\right)$, basin lagtime (LT), and flood volume $\left(V_{100}\right)$ to changes in storage area (ST) when simulating 100-year flood hydrographs.

The effects of ST on simulated hydrograph shape are shown in figure 19. The taller hydrograph (solid line) is the simulated hydrograph of the estimated 100-year peak discharge for the correct ST value of 0.3 percent. The shorter hydrograph (dashed line) is the corresponding hydrograph using an incorrect ST value of 3.0 percent. Use of the 3.0-percent ST value decreased $Q_{100}$ by 34 percent, increased LT by 42 percent, and decreased $\mathrm{VQ}_{100}$ by 6 percent. The increase in storage area causes a decrease in peak discharge which, in turn, causes a decrease in volume. Most of this decrease in volume, however, is offset by a corresponding increase in volume caused by the increase in basin lagtime--hence the net decrease in $\mathrm{VQ}_{100}$ of 6 percent. The decrease in $\mathrm{VQ}_{100}$ indicates that, as ST increases, less total runoff volume is discharged as direct runoff under the simulated hydrograph, and more of the total runoff volume is discharged as sustained flow (coming out of storage) occurring later in time than the simulated hydrograph. 


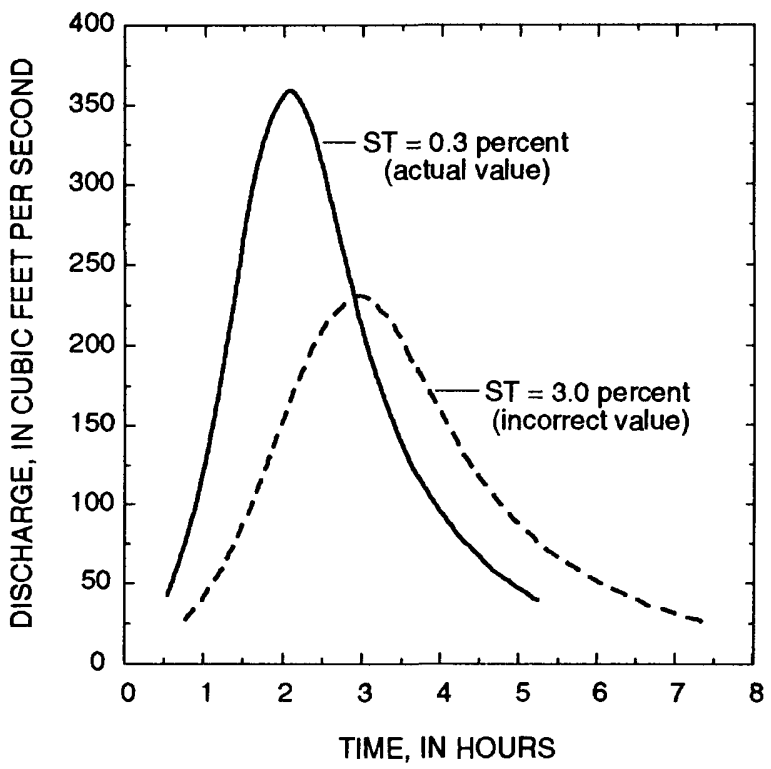

Figure 19.--Simulated flood hydrographs of estimated 100-year peak discharge illustrating the effects of storage area (ST) on hydrograph shape.

\section{COMPARISON OF VOLUME- ESTIMATION TECHNIQUES}

The preceding sections describe two methods for estimating flood volumes. Figure 20 is a graph comparing the volume-duration curve estimated from the 100 -year volumeduration-frequency $\left(\mathrm{dV}_{100}\right)$ equations (equations 33 to 36 and 41 to 42 ) with the volumeduration curve estimated by integrating under the simulated hydrograph for the 100-year peak discharge $\left(\mathrm{VQ}_{100}\right.$, fig. 17) for an ungaged rural stream in eastern Adams County, Ohio. Both curves represent the maximum estimated volume for the indicated duration as illustrated in figure 5 . In the example shown in figure 20, both methods of volume computation produce similar results up to a duration of about 3 hours. The $\mathrm{VQ}_{100}$ curve ends at 4.69 hours (total duration (D) of the simulated hydrograph) with a relatively small increase in volume from 3 to 4.69 hours. The $d V_{100}$ curve ends at 32 hours with a significant increase in volume from 3 to 32 hours.

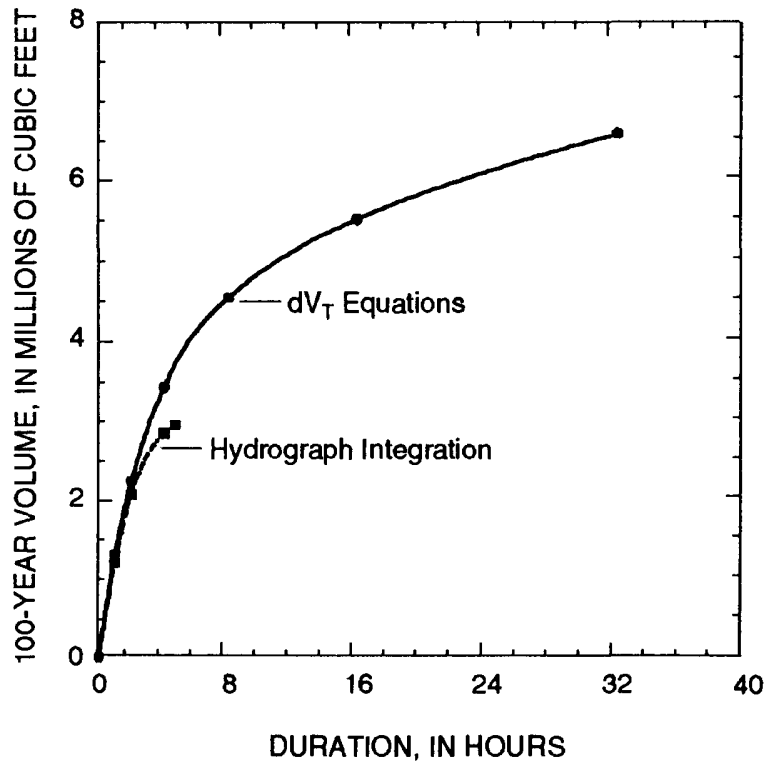

Figure 20.--Volume estimated from 100-year volume-duration-frequency equations and volume integrated under 100-year estimated peak-discharge hydrograph for an ungaged rural stream in eastern Adams County, Ohio.

Estimates of volume obtained by application of the volume-duration-frequency $\left(\mathrm{dV}_{\mathrm{T}}\right)$ equations are not intended to replace the volume estimates obtained by integrating the area under an estimated hydrograph, but rather to provide additional information for design situations in which a significant volume of water needs to be stored, such as a high-fill roadway embankment with a small-diameter culvert. Both methods should yield similar results for estimates of short-duration volumes; however, for estimates of long-duration volumes, the $\mathrm{dV}_{\mathrm{T}}$ equations should provide a more conservative (larger) estimate because the $d V_{T}$ equations are based on maximum-annual-volume data. The dimensionless-hydrograph method is based on flood hydrographs of average duration and cannot be used to estimate longduration volumes. It may be necessary to estimate flood hydrographs for many design situations because the hydrographs provide a means of routing discharges through a hydraulic structure so that concurrent outflow discharges can be estimated. 
The two methods, in effect, provide estimates of resultant runoff volumes from two different types of storms, both of which occur regularly in Ohio. The $\mathrm{dV}_{\mathrm{T}}$ equations would be more appropriate for estimating runoff volumes from frontal-type storms characterized by moderate to heavy rainfall of long duration; whereas, the hydrograph method would be more appropriate for estimating runoff volumes from convective-type storms (thunderstorms) characterized by intense rainfall of average duration.

The method of estimating volumes by use of the $\mathrm{dV}_{\mathrm{T}}$ equations is a more direct computation because the volumes are computed directly from the basin characteristics, which can be measured. In contrast, the method of estimating volumes by use of hydrograph integration is a less direct computation because the computed volumes depend upon estimated basin lagtime (which is quite variable and difficult to estimate accurately) and estimated peak discharge.

\section{SUMMARY}

An 8-year flood-volume study was conducted to develop methods to estimate volumeduration-frequency relations and simulate flood hydrographs of small rural streams in Ohio. The methods were developed to assist planners in the design of hydraulic structures for which the temporary storage of water is an important element of the design criteria or where hydrograph routing is required.

Five-minute rainfall-runoff data were collected for a period of 5 to 8 years at 62 small basins (less than 6.5 square miles) located throughout Ohio. The U.S. Geological Survey rainfall-runoff model A634 was calibrated for each site. The calibrated models were used in conjunction with long-term (66-87 years) rainfall and evaporation records to synthesize a long-term series of flood-hydrograph records at each site. The largest runoff volume for each of six durations $(1,2,4,8,16$, and
32 hours) was computed for each water year of synthetic hydrograph data. A method was developed and used to increase the variance of the synthetic flood characteristics in order to make them more representative of observed flood characteristics. The logarithms of the annual peak volumes for each duration were fit by a Pearson Type III frequency distribution to develop a volume-duration-frequency relation for each site.

The volume-duration-frequency data were related to the basin characteristics of the 62 sites by multiple-regression analysis. Multiple-regression equations were developed to estimate maximum flood volumes of $d$-hour duration and T-year recurrence interval $\left(\mathrm{dV}_{\mathrm{T}}\right)$. Flood-volume data for all combinations of six durations (1, 2, 4, 8, 16, and 32 hours) and six recurrence intervals $(2,5,10,25,50$, and 100 years) were analyzed. The explanatory variables in the resulting equations are drainage area, average annual precipitation, mainchannel slope, and forested area. Average standard errors of prediction for the $\mathrm{dV}_{\mathrm{T}}$ equations range from \pm 28 percent to \pm 44 percent.

A method was presented to simulate flood hydrographs by applying a specific peak discharge and an estimated basin lagtime to a dimensionless hydrograph. Peak discharge may be estimated from equations in which drainage area, main-channel slope, and storage area are the explanatory variables, and average standard errors of prediction range from 33 to

41 percent. An equation was developed to estimate basin lagtime in which main-channel slope, forested area, and storage area are the explanatory variables, and the average standard error of prediction is \pm 37 percent. A dimensionless hydrograph developed by the U.S. Geological Survey for use in Georgia was verified for use in rural areas of Ohio.

Examples of how to use the methods are presented. Volumes estimated by use of the volume-duration-frequency equations were compared with volumes estimated by integrating under a simulated hydrograph. Both 
methods yield similar results for volume estimates of short duration, which are applicable to convective-type storm runoff. The volumeduration-frequency equations can be used to compute volume estimates of long and short duration because the equations are based on maximum-annual-volume data of long and short duration. The dimensionless-hydrograph method is based on flood hydrographs of average duration and cannot be used to compute volume estimates of long duration. Volume estimates of long duration may be considerably greater than volume estimates of short duration and are applicable to runoff from frontal-type storms.

\section{REFERENCES CITED}

Becker, L.D., 1980, Techniques for estimating flood peaks, volumes, and hydrographs on small streams in South Dakota: U.S. Geological Survey WaterResources Investigations Report 80-80, 82 p.

Bodhaine, G.L., 1968, Measurement of peak discharge at culverts by indirect methods: U.S. Geological Survey Techniques of Water-Resources Investigations, book 3, chap. A3, $60 \mathrm{p}$.

Boning, C.W., 1974, User's guide for a U.S. Geological Survey rainfall-runoff model: U.S. Geological Survey Open-File Report 74-33, 252 p.

Carrigan, P.H., Jr., 1973, Calibration of U.S. Geological Survey rainfall-runoff model for peak flow synthesis--Natural basins: U.S. Geological Survey Computer Contribution, $114 \mathrm{p}$.

Carrigan, P.H., Jr., Dempster, G.R., Jr., and Bower, D.E., 1977, User's guide for U.S. Geological Survey rainfall-runoff models--Revision of Open-File Report 77-33:U.S. Geological Survey Open-File Report 77-884, $260 \mathrm{p}$.

Craig, G.S., and Rankl, J.G., 1978, Analysis of runoff from small drainage basins in Wyoming: U.S. Geological Survey Water-Supply Paper 2056, 70 p.

Dawdy, D.R., Lichty, R.W., and Bergmann, J.M., 1972, A rainfall-runoff model for estimation of flood peaks for small drainage basins: U.S. Geological Survey Professional Paper 506-B, 28 p.
Franklin, M.A., 1984, Magnitude and frequency of flood volumes for urban watersheds in Leon County, Florida: U.S. Geological Survey Water-Resources Investigations Report 84-4233, 20 p.

Hardison, C.H., 1971, Prediction error of regression estimates of streamflow characteristics at ungaged sites: U.S. Geological Survey Professional Paper 750-C, p. C228-C236.

Harstine, L. J., 1991, Hydrologic atlas for Ohio: Average annual precipitation, temperature, streamflow, and water loss for 50-year period, 1931-1980: Ohio Department of Natural Resources, Division of Water, Water Inventory Report No. 28, 13 p., 4 pl.

Hutchinson, N.E., compiler, 1975, WATSTORE, National water data storage and retrieval system-User's guide, v. 1: U.S. Geological Survey OpenFile Report 75-426, 505 p.

Inman, E.J., 1987, Simulation of flood hydrographs for Georgia streams: U.S. Geological Survey WaterSupply Paper 2317, $24 \mathrm{p}$. (formerly published in 1986 as U.S. Geological Survey Water-Resources Investigations Report 86-4004)

1988, Flood-frequency relations for urban streams in Georgia: U.S. Geological Survey WaterResouces Investigations Report 88-4085, 36 p.,

Interagency Advisory Committee on Water Data, 1982, Guidelines for determining flood flow frequency: Bulletin 17B of the Hydrology Subcommittee, $183 \mathrm{p}$.

Jennings, M.E., 1977, Downstream-upstream reservoir routing: U.S. Geological Survey Computer Program Documentation--User's manual, $42 \mathrm{p}$.

Kirby, W.H., 1975, Model smoothing effect diminishes simulated flood peak variances: American Geophysical Union Transactions, v. 56, no. 6, 361 p.

Koltun, G.F., and Roberts, J.W., 1990, Techniques for estimating flood-peak discharges of rural, unregulated streams in Ohio: U.S. Geological Survey Water-Resources Investigations Report 89-4126, $68 \mathrm{p}$. 
Lichty, R.W., and Liscum, F., 1978, A rainfall-runoff modeling procedure for improving estimates of $\mathrm{T}$ year (annual) flood for small drainage basins: U.S. Geological Survey Water-Resources Investigations Report 78-7, 44 p.

Montgomery, D.C., and Peck, E.A., 1982, Introduction to linear regression analysis: New York, Wiley, $504 \mathrm{p}$.

Newton, D.W., and Herrin, J.C., 1982, Assessment of commonly used flood frequency methods: Transportation Research Record Series TRR896, 30 p.

O'Donnell, Terrance, 1960, Instantaneous unit hydrograph derivation by harmonic analysis: International Association of Scientific Hydrology, Publication 51, p. 546-557.

Ohio Department of Natural Resources, Division of Soil and Water Conservation, 1981, Ohio stormwater control guidebook, $48 \mathrm{p}$.

Robbins, C.H., 1986, Techniques for simulating flood hydrographs and estimating flood volumes for ungaged basins in central Tennessee: U.S. Geological Survey Water-Resources Investigations Report 86-4192, 32 p.

Rosenbrock, H.H., 1960, An automatic method of finding the greatest or least value of a function: Computer Journal, v. 3, p. 175-184.

SAS Institute, 1982, SAS User's guide--Statistics, 1982 edition: Cary, N.C., 584 p.

Sauer, V.B., Thomas, W.O., Jr., Stricker, V.A., and Wilson, K.V., 1983, Flood characteristics of urban watersheds in the United States: U.S. Geological Survey Water-Supply Paper 2207, 63 p.
Sherwood, J.M., 1985, Preliminary report on a study to estimate flood volumes of small rural streams in Ohio: Methods, site selection, and data base: U.S. Geological Survey Open-File Report 84-470, 138 p.

1986, Estimating peak discharges, fiood volumes, and hydrograph shapes of small ungaged urban streams in Ohio: U.S. Geological Survey WaterResources Investigations Report 86-4197, 52 p.

1993, Estimation of peak-frequency relations, flood hydrographs, and volume-duration-frequency relations of ungaged small urban streams in Ohio: U.S. Geological Survey Open-File Report 93-135, $53 \mathrm{p}$.

Stricker, V.A., and Sauer, V.B., 1982, Techniques for estimating flood hydrographs for ungaged urban watersheds: U.S. Geological Survey Open-File Report 82-365, 24 p.

Thomas, D.M., and Benson, M.A., 1970, Generalization of streamflow characteristics from drainage-basin characteristics: U.S Geological Survey WaterSupply Paper 1975, 55 p.

Thomas, W.O., 1982, An evaluation of flood frequency estimates based on rainfall/runoff modeling: Water Resources Bulletin, v. 18, no. 2, p. 221-230.

U.S. Department of Commerce, 1961, Rainfall frequency atlas of the United States: U.S. Weather Bureau Technical Paper 40, $115 \mathrm{p}$.

Webber, E.E., and Bartlett, W.P., Jr., 1977, Floods in Ohio--magnitude and frequency: Ohio Department of Natural Resources Division of Water Bulletin 45, $74 \mathrm{p}$. 